\title{
Communicable Diseases in Homo sapiens for Immunologists
}

\author{
Davies AJS* \\ Emeritus Professor, University of London, POLYREM Ltd, 81 Queens Road, Wimbledon, London, England
}

${ }^{\star}$ Corresponding author: AJS Davies, Emeritus Professor, University of London, POLYREM Ltd, 81 Queens Road, Wimbledon, London, England; Tel: 442089447734; E-mail: tony.davies@blueyonder.co.uk

Received: September17, 2020; Accepted: September 24, 2020; Published: September 30, 2020

\section{Introduction}

In 1917 the American Public Health Association, (APHA), began to publish a manual dedicated to the Control of Communicable Diseases in man. The publication has been updated about every five years. The $20^{\text {th }}$ edition was published in 2015 and the next edition is scheduled to come out in 2021 . What follows is largely based on the $20^{\text {th }}$ edition [1] though over the years the present author has looked at the manual in its $11^{\text {th }}, 17^{\text {th }}$ and $18^{\text {th }}$ editions, this last in disc format. This remarkable and extremely useful document is intended primarily for Public Health practitioners and includes detailed guidance for them in relation to the steps to be taken in the event of an outbreak of any of the diseases considered. For immunologists interested in infectious disease it offers a wealth of opportunities for research and could help them to gain a better perception of the biological significance of the immune response. It also could help them better to recognise the two systems of immunity, innate and adaptive, the former an attribute of all animals with an alimentary canal and the latter found only in vertebrates. The functional relationships between the two systems of immunity are important but differ in relation to the scale of generation of immunopathological effects regulation of which is increasingly seen as important in dealing with infectious disease.

The recent outbreak of disease associated with Covid-19, the worst symptoms of which are associated with so-called cytokine storms, suggests that the simple model of thinking of immunity, as consisting of antigens originating from infectious organisms, eliciting the formation of specific antibodies which can help the rejection of the invader, needs revision. Much high-quality immunological research conducted since the Second-World War has had a reductionist flavour, very sensibly, as cutting down uncontrollable variables is seen as an integral part of experimental biological research. For example, measurement of adaptive immunity has often involved analysis of antibody arrays following the introduction of highly simplified antigenic epitopes often perched on the backs of carrier proteins which are supposedly not involved actively in the specification of the reaction to the target epitope which they convey. A problem also not addressed by the immunological communities is how the immunologically responding organism deals with the complex array of epitopes capable, using analytic methodology, of eliciting a specific antibody response without overloading the responsive system. There has also often been only restricted means of following the physiological consequences of the activation of the large numbers of the cells which are part of the overall immunological processes including, importantly, non-specific activation of the innate system following the creation of dead dying and damaged cells as a consequence of infection.

Many experimental immunologists faced with the measurement of a response to an antigenic array which is increasing exponentially from the time of first contact, as happens with many infections, will be hard pushed to predict the outcome. Their experiences will often be largely concerned with non-living antigenic arrays given once or twice to demonstrate the scale of a response and that by evocation, it is argued, of various memory cells the adaptive immune response is usually more reactive on second contact with the antigens concerned. That this paradigm is useful it not to be denied as it supports the whole fabric of the vaccinologists and has led to the eradication of small-pox as a highly dangerous disease world-wide and, in many countries, the extirpation of what can be the unpleasant consequences of contact with poliomyelitis virus. Nevertheless, it is becoming increasingly apparent that the proportion of the total array of potentially infectious organisms which cause disease, particularly viruses and bacteria, is tiny. In addition, it is being argued that humans and similar triploblastic animals carry thousands of species of bacteria and an unknown multitude of viruses. Most of which of these foreign organisms should probably be regarded as commensal or symbiotic though it also includes a few potential pathogens. This enormous array of organisms, which are an integral part of us, can under some circumstances do harm but, in the sense that overall, they do good rather than damage, should perhaps not all be termed infections which, by definition, carries the intent to do harm. It is becoming increasingly important that we better understand the precise terms of the often stable and symptom free relationship between these foreign invaders and the host organisms.

The APHA manual, from which much can be learned, deserves more attention from the immunologists interested in infectious disease. The present paper, intending to extract from the manual 
generalisations and initiate explorations of the mechanisms of disease processes, will be of help to immunologists interested in the field of infectious disease. Whether it will be of help to the public health practitioners, for whom the manual is primarily intended, remains to be seen. It should be made clear that what follows is in no way intended to replace the Manual but simply to draw the attention of immunologists to read through it and to pay attention to some issues which should interest them and which, otherwise, they might not be aware of. The Manual is compiled from the writings of many specialists in relation to the 250 or so diseases that are considered in outline. Often the experts on, say, malaria know little about diseases caused by viruses and this compartmentalisation can restrict the development of useful generalisations about the processes involved in disease. What will be offered is intended for immunologists to help them, not only better to frame such generalisations and, hopefully, to better understand the complexity of their subject as a mutually reactive device acting at the interface between many living organisms and, in the broad sense, their environment.

It should be noted that all infectious organisms will be labelled parasites which often, by parasitologists is a nomenclature reserved for multicellular eukaryotic organisms. The implication is that if the host of an invader can be damaged at the expense of the host whatever the nature of the invader a state of parasitism exists. In addition, it should be made clear that what follows has a large subjective element emerging from the mind of an individual who, with the support of many scientific colleagues over the last sixty years or so, has been an experimental immunobiologist.

\section{Methods}

The APHA manual is presented in a stylised manner with diseases and groups of diseases presented alphabetically. Within each of the listed diseases or groups of diseases are given their WHO ICD 9 and ICD 10 categorisations, their names with some of the synonyms are given followed by eight sets of basic information labelled, respectively, Identification, Infectious agent, Occurrence, Reservoir, Mode of Transmission, Incubation period, Period of communicability and Susceptibility and Resistance. There follows what is often a more extensive ninth section on Methods of Control aimed primarily at Public Health workers in relation to diseases with major social impact that can be epidemic or even pandemic. The present author elected to draw out, largely from information given in sections one to eight of the diseases in the manual, a categorisation based primarily on the causal infective organisms, i.e. Bacteria, Viruses, Fungi, Protoctista/Protozoa, Trematodes, Nematodes and a Miscellaneous group with such causal 'organisms' as arachnids, prions and diseases in some instances where the taxonomic classification of the causal agency is not certain. For each class of infective organism tables were constructed with a matrix listing each disease in relation to the Identity of the causal organism, the Geographical location of the disease occurrence(s), the Class of Disease on the WHOICD lists of diseases, an indication of its Impact, Susceptibility, Special risk factors, Immunity, Vaccines where used, primary Reservoir, Vectors and general Comments with in some instances a brief indication of the Treatments available.
Each of the Tables 1-7 is accompanied by a short summarising statement drawing attention to items of special interest. Table 8 labelled Reconciliation, aims to enable immunologists, to gain a better outline of the scale and range of the infective diseases which, ideally, are the targets of activity their immunological discipline aspires to understand and learn how to regulate. Sheep red cells, which have been a common feature of immunological investigations in mice, do not, usually, cause disease neither do they grow exponentially in the organism to which they have been placed.

\section{Results}

\section{Bacteria}

There are sixty or so diseases written about which are associated with bacterial infection. This number does not include the oftennumerous related species of bacteria that cause disease in the category mainly dealt with but for all that it is clear that, although there are millions of bacterial spp. known, only very few of them are pathogenic. Perhaps more importantly it should be noted that the microbiome array in man of several thousand species often includes only very few that become pathogenic. Selected information derived from the Manual concerning bacteria is given in Table 1 .

About one third of bacterial diseases are labelled chronic. Clearly there are problems of definition with this epithet. It is evident that a considerable number of diseases can either be acute with no persistence of the causal infecting organism or chronic with persistence. The issue of whether when there is no persistence of the infective organism, but retention of an immunological memory will be discussed elsewhere in this paper. Sometimes when a parasite does not persist, perhaps as consequence of treatment, there is no obvious residual immunological memory (for example some Chlamydial infections, Lyme disease, listeriosis). On the other hand, the diseases caused by certain Rickettsia spp seem to lead to lifelong immunity even post treatment aimed at the causal organism. Is this a clear example of persistence of immunological memory? If it is, what is the difference between, say, Listeria and Rickettsia that leads to the differences in post hoc immunological memory? In cases of salmonellosis, many of which recover spontaneously albeit with periods of discomfort in between, there seems to be no immunological memory. In fact, there is no evidence given in the manual for any immune response. How was the parasite brought under control? In the instance of Salmonella infections it is clear that the initial dose of infection can determine the severity of the disease that arises. With some other bacteria, Shigella, for example, only very few organisms are required to initiate an infection the severity of which is not determined by the starting dose but by other factors. It is not clear whether Shigella activates the immune response. The manual says only that up to $40 \%$ of households show second attacks. On this basis using the standard immunological paradigms if there is immunity it is sometimes transient and relatively ineffective. Later in this paper evidence will be presented that the normal gut flora normally attracts little if any attention from the adaptive immune apparatus and this might be the situation in relation to Salmonella and Shigella which are primarily infections of the gut. 
Table 1: Bacteria.

\begin{tabular}{|c|c|c|c|c|c|c|c|c|c|}
\hline Disease & $\begin{array}{l}\text { Infectious agent.Target } \\
\text { organ if any. }\end{array}$ & Location & \begin{tabular}{|l} 
ICD 10entry. \\
Impact
\end{tabular} & Susceptibility & Special risk factors & Immunity & Vaccines & $\begin{array}{l}\text { Primary reservoir } \\
\text { and vectors }\end{array}$ & Comments, treatment \\
\hline Actinomycosis & $\begin{array}{l}\text { Actinomyces israelii and } \\
\text { others of the same genus } \\
\text { Chronic disease } \\
\text { located in orocervical } \\
\text { facial, thoracic and } \\
\text { abdominopelvic regions }\end{array}$ & $\begin{array}{l}\text { Sporadic throughout } \\
\text { the world }\end{array}$ & $\begin{array}{l}\text { A42 } \\
\text { rare disease small } \\
\text { impact }\end{array}$ & low & $\begin{array}{l}\text { Frequency maximal between } \\
20 \text { and } 60 \text { years of age. Mucosal } \\
\text { barrier disruption caused } \\
\text { by surgery or irradiation, } \\
\text { and immunocompromising } \\
\text { conditions. }\end{array}$ & Not demonstrated & N/A & humans & \begin{tabular}{|l|} 
Reasonably common \\
component of oral flora. Can \\
cause problems following \\
trauma that allows access. \\
Prolonged administration of \\
penicillin can be effective.No \\
spontaneous recovery. \\
\end{tabular} \\
\hline $\begin{array}{l}\text { Anthrax,Woolsorter disease, } \\
\text { ragpicker disease. }\end{array}$ & \begin{tabular}{|l|} 
Bacillus anthracis. Three \\
forms depending on \\
route if introduction. \\
Cutaneous, inhalation, \\
gastrointestinal \\
occasionally among drug \\
users.
\end{tabular} & $\begin{array}{l}\text { S and Central } \\
\text { America, S and E } \\
\text { Europe, Asia and } \\
\text { Africa }\end{array}$ & $\begin{array}{l}\text { A22 } \\
\text { Primarily a disease } \\
\text { of herbivores }\end{array}$ & Uncertain & \begin{tabular}{|l|} 
A zoonosis. An infrequent \\
or sporadic disease among \\
veterinarians, wild life workers \\
and agricultural workers.
\end{tabular} & \begin{tabular}{|l|} 
Second attacks rare. \\
Immunisation for \\
individuals at high risk \\
because of their location \\
or occupation. Using a cell \\
free isolate is said to be \\
effective.
\end{tabular} & $\begin{array}{l}\text { For animals and } \\
\text { those humans at } \\
\text { occupational risk }\end{array}$ & $\begin{array}{l}\text { Animals and viable } \\
\text { spores can persist in } \\
\text { soil for decades }\end{array}$ & $\begin{array}{l}\text { Widely bruited as a weapon } \\
\text { for terrorism though } \\
\text { it has probably not yet } \\
\text { been deployed. Complex } \\
\text { regimens of post exposure } \\
\text { prophylaxis are deployed. }\end{array}$ \\
\hline $\begin{array}{l}\text { Bartonellosis(Oroya fever, } \\
\text { Verruga Peruana, Carrion } \\
\text { Disease-) }\end{array}$ & $\begin{array}{l}\text { Bartonella bacilliformis } \\
\text { Either a life threatening } \\
\text { febrile anaemia (Oroyo } \\
\text { fever) or a benign dermal } \\
\text { eruption (Verruga } \\
\text { Peruana). There are many } \\
\text { spp.Of Bartonellawith } \\
\text { much more complex } \\
\text { patterns of infection than } \\
\text { shown in the manual. } \\
\text { See also Cat Scratch fever } \\
\text { and Trench Fever. }\end{array}$ & $\begin{array}{l}\text { Mountain valleys of } \\
\text { Peru, Ecuador and } \\
\text { Southwest Columbia } \\
\text { between altitudes of } \\
2000 \text { and } 9,200 \text { feet } \\
\text { where sand flies are } \\
\text { present }\end{array}$ & $\begin{array}{l}\text { A44.0, A44.1 } \\
\text { Mortality with } \\
\text { untreated oroya } \\
\text { fever can be as high } \\
\text { as ninety per cent }\end{array}$ & General & $\begin{array}{l}\text { More severe in adults than in } \\
\text { children. Most common in } \\
\text { tourists, i.e., immunologically } \\
\text { naive individuals. }\end{array}$ & $\begin{array}{l}\text { Inapparent infections and } \\
\text { carriers are known(up } \\
\text { to } 5 \% \text { in endemic } \\
\text { areas).Recovery from } \\
\text { untreated Oroya fever } \\
\text { almost invariably leads } \\
\text { to permanent immunity } \\
\text { though the Verruga stage } \\
\text { may recur. Asymptomatic } \\
\text { infections and a carrier } \\
\text { state are known. }\end{array}$ & N/A & $\begin{array}{l}\text { Humans, no known } \\
\text { animal reservoir. } \\
\text { Vector sand flies. }\end{array}$ & $\begin{array}{l}\text { Treatment with antibiotics } \\
\text { can be partly successful. }\end{array}$ \\
\hline $\begin{array}{l}\text { Intestinal Botulism, Infant } \\
\text { Botulism }\end{array}$ & $\begin{array}{l}\text { Clostridium botulinum is } \\
\text { the source of botulinum } \\
\text { neurotoxin that causes } \\
\text { the disease. Other } \\
\text { spp of the genus can } \\
\text { be involved.Severe } \\
\text { neuropathogenic disease. } \\
\text { Respiratory failure } \\
\text { common cause of death. }\end{array}$ & $\begin{array}{l}\text { Worldwide, sporadic, } \\
\text { family, and general } \\
\text { outbreaks are } \\
\text { associated with } \\
\text { imperfect food } \\
\text { preparation }\end{array}$ & $\begin{array}{l}\text { A05.1cumulative } \\
\text { cases world wide } \\
\text { of which } 1400 \\
\text { were from the } \\
\text { USA. Nevertheless } \\
\text { regarded as amajor } \\
\text { hazard presumably } \\
\text { because of its high } \\
\text { lethality. }\end{array}$ & General & $\begin{array}{l}\text { Almost all hospitalised patients } \\
\text { were between two weeks and } \\
\text { one year of age. } 94 \% \text { were less } \\
\text { than six months!. Adults with } \\
\text { bowel problems or treated with } \\
\text { antibiotics can be at special } \\
\text { risk. The use of botulinum } \\
\text { toxin has been associated with } \\
\text { the development of iatrogenic } \\
\text { disease. }\end{array}$ & ? & $\begin{array}{l}\text { Antitoxin is } \\
\text { administered } \\
\text { presumably as a } \\
\text { passively given } \\
\text { antibody. There } \\
\text { seems to have been } \\
\text { no attempt at active } \\
\text { immunisation. }\end{array}$ & $\begin{array}{l}\text { Spores in soil, } \\
\text { ubiquitous }\end{array}$ & \begin{tabular}{|l|} 
In effect a disease of the food \\
industry. Most problems \\
are caused not by ingestion \\
of preformed toxin but \\
of bacterial spores that \\
germinate to give rise to \\
more organisms that secrete \\
the toxin.Important as a \\
potential bioterrorism tool. \\
I.V. antitoxin
\end{tabular} \\
\hline Disease & \begin{tabular}{|l} 
Infectious agent. \\
Target organ if any.
\end{tabular} & Location & $\begin{array}{l}\text { ICD } 10 \text { entry. } \\
\text { Impact }\end{array}$ & Susceptibility & Special risk factors & Immunity & Vaccines & $\begin{array}{l}\text { Primary reservoir } \\
\text { and vectors }\end{array}$ & Comments, treatment \\
\hline $\begin{array}{l}\text { Brucellosis, undulant fever, } \\
\text { Malta fever, Mediterranean } \\
\text { fever }\end{array}$ & $\begin{array}{l}\text { Brucella abortus in a } \\
\text { variety of strains } \\
\text { A systemic disease. } \\
\text { Very complex pattern of } \\
\text { symptoms }\end{array}$ & Worldwide & \begin{tabular}{|l|} 
A23 \\
Less now than \\
heretofore. Incidence \\
in USA 120 current \\
cases. In other \\
parts of the world \\
probably unreported \\
and undiagnosed.
\end{tabular} & $\begin{array}{l}\text { Severity and duration of } \\
\text { clinical illness subject } \\
\text { to wide (unexplained) } \\
\text { variation. }\end{array}$ & $\begin{array}{l}\text { A disease of those working } \\
\text { with farm animals abattoir, } \\
\text { vets, or direct contact with } \\
\text { animals. Persons eating } \\
\text { uncooked meat are at higher } \\
\text { risk. }\end{array}$ & Unknown & $\begin{array}{l}\text { None in man but } \\
\text { active successful } \\
\text { immunisation of cattle } \\
\text { is practised. }\end{array}$ & $\begin{array}{l}\text { Cattle, swine, goats } \\
\text { and pigs. }\end{array}$ & $\begin{array}{l}\text { It has been suggested that } \\
\text { infection with Brucella } \\
\text { was a negative indication } \\
\text { for cancer. Equally several } \\
\text { suggestions have been made } \\
\text { that brucella antigens could } \\
\text { help suppress cancer. The } \\
\text { evidence so far is slender. } \\
\text { Anti Biotics }\end{array}$ \\
\hline
\end{tabular}




\begin{tabular}{|c|c|c|c|c|c|c|c|c|c|}
\hline $\begin{array}{l}\text { Campylobacter enteritis, } \\
\text { Vibrionic enteritis }\end{array}$ & $\begin{array}{l}\text { Campylobacter jejunis } \\
\text { Diarrhea. }\end{array}$ & Worldwide & $\begin{array}{l}\text { A } 04.514 \% \text { of } \\
\text { diarrhoea worldwide } \\
\text { caused by these } \\
\text { organisms. }\end{array}$ & $\begin{array}{l}\text { Many infections are } \\
\text { asymptomatic }\end{array}$ & $\begin{array}{l}\text { Children under five and } \\
\text { young adults are at higher } \\
\text { risk. Immunocompromised } \\
\text { individuals at higher risk. }\end{array}$ & & None & \begin{tabular}{|l|} 
Poultry and cattle \\
mainly but many \\
other animals. Most \\
raw poultry meat \\
contaminated! \\
\end{tabular} & \begin{tabular}{|l|} 
Common disease with \\
considerable impact. \\
Treatment not generally \\
indicated! Rehydration and \\
electrolytes. \\
\end{tabular} \\
\hline $\begin{array}{l}\text { Cat Scratch Disease, benign } \\
\text { lymphoreticulosis }\end{array}$ & $\begin{array}{l}\text { Bartonella benselae } \\
\text { Subacute usually } \\
\text { self limiting disease. } \\
\text { Affecting lymphoid } \\
\text { system and often causing } \\
\text { fever }\end{array}$ & $\begin{array}{l}\text { Worldwide but } \\
\text { uncommon }\end{array}$ & $\begin{array}{l}\text { A28.1 } \\
\text { Slight }\end{array}$ & unknown & \begin{tabular}{|l|} 
Immuno-compromised \\
hosts most infected but some \\
evidence that younger children \\
and younger adults are more \\
affected
\end{tabular} & $\begin{array}{l}\text { Diagnosis sometimes } \\
\text { based on serological } \\
\text { evidence of anti- } \\
\text { Bartonellaantibody. }\end{array}$ & None & $\begin{array}{l}\text { Domestic cats. There } \\
\text { is no evidence of } \\
\text { adverse effects on } \\
\text { cats even when they } \\
\text { are bacteremic }\end{array}$ & \begin{tabular}{|l|} 
Interesting example though \\
too little is known about it to \\
place much weight on it. The \\
fact that infected cats are \\
asymptomatic is noteworthy. \\
Antibiotics \\
\end{tabular} \\
\hline $\begin{array}{l}\text { Chancroid, ulcusmolle, soft } \\
\text { chancre }\end{array}$ & $\begin{array}{l}\text { Haemophilus ducreyi } \\
\text { STD }\end{array}$ & $\begin{array}{l}\text { Sporadic. Less in } \\
\text { temperate regions }\end{array}$ & $\begin{array}{l}\text { A57 } \\
\text { small }\end{array}$ & $\begin{array}{l}\text { No natural resistance, the } \\
\text { circumcised are at less risk. }\end{array}$ & Men who frequent prostitutes! & None recorded & None & Humans & $\begin{array}{l}\text { Unpleasant condition with } \\
\text { too little-known. Antibiotics }\end{array}$ \\
\hline $\begin{array}{l}\text { Chlamydial infections, Genital } \\
\text { (psittacosis and respiratory } \\
\text { disease dealt with separately) }\end{array}$ & $\begin{array}{l}\text { Chlamydia trachomatitis } \\
\text { STD }\end{array}$ & Common & $\begin{array}{l}\text { A56 } \\
\text { Nuisance rather than } \\
\text { major threat }\end{array}$ & $\begin{array}{l}\text { General, majority of infected } \\
\text { women are asymptomatic, } \\
\text { up to } 25 \% \text { of infected males } \\
\text { the same. }\end{array}$ & None given & $\begin{array}{l}\text { No acquired immunity } \\
\text { has been demonstrated. } \\
\text { Repeated infections } \\
\text { common. }\end{array}$ & N/A & humans & \begin{tabular}{|l|} 
Common, seems to have \\
little if any impact on \\
immunological mechanisms. \\
Antibiotics can render \\
patients non-infectious. \\
\end{tabular} \\
\hline Disease & $\begin{array}{l}\text { Infectious agent. } \\
\text { Target organ if any. }\end{array}$ & Location & $\begin{array}{l}\text { ICD } 10 \text { entry. } \\
\text { Impact }\end{array}$ & Susceptibility & Special risk factors & Immunity & Vaccines & $\begin{array}{l}\text { Primary reservoir } \\
\text { and vectors }\end{array}$ & Comments, treatment \\
\hline $\begin{array}{l}\text { Vibrio parahemolyticus } \\
\text { infection }\end{array}$ & $\begin{array}{l}\text { Vibrio parahemolyticus } \\
\text { Enteritis }\end{array}$ & $\begin{array}{l}\text { Sporadic in many } \\
\text { parts of the world. } \\
\text { Marine coastal } \\
\text { environments }\end{array}$ & $\begin{array}{l}\text { A } 05.3 \\
\text { A disease of } \\
\text { moderate severity. } \\
\text { Rarely systemic or } \\
\text { lethal } \\
\end{array}$ & $\begin{array}{l}\text { Various anterior medical } \\
\text { conditions such as } \\
\text { liver disease, decreased } \\
\text { gastric acidity or } \\
\text { immunosuppression. } \\
\end{array}$ & oysters & No indication given & None & Marine silt & Rehydration, antibiotics \\
\hline Vibrio vulnificus & $\begin{array}{l}\text { Vibrio vulnificus. } \\
\text { Septicaemia commonly } \\
\text { but other symptoms } \\
\text { encountered. }\end{array}$ & $\begin{array}{l}\text { Marine environments } \\
\text { particularly but not } \\
\text { exclusively in N. } \\
\text { America. }\end{array}$ & $\begin{array}{l}\text { A } 05.3 \\
\text { Septicaemia fatal in } \\
50 \% \text { of cases }\end{array}$ & $\begin{array}{l}\text { Characteristically in } \\
\text { patients with chronic } \\
\text { liver disease, alcoholism, } \\
\text { hemochromatosis or } \\
\text { immunosuppression. }\end{array}$ & $\begin{array}{l}\text { Oysters. Sea water exposure of } \\
\text { open wounds. }\end{array}$ & No indication given & None & \begin{tabular}{|l|} 
Free living organism \\
in estuarine \\
environments. \\
Uncooked sea food \\
can be source of \\
infection \\
\end{tabular} & Rehydration, antibiotics \\
\hline $\begin{array}{l}\text { Cholera(serotypes other than } \\
01 \text { and } 0139 \text { ) }\end{array}$ & $\begin{array}{l}\text { Vibrio cholera Enteritis } \\
\text { and otitis media, and } \\
\text { cellulitis. }\end{array}$ & \begin{tabular}{|l|}
$2-3 \%$ of cases of \\
diarrhoea (including \\
travellers)in tropical \\
countries
\end{tabular} & $\begin{array}{l}\text { A05.81Small relative } \\
\text { to the pathogenic } 01 \\
\text { and } 0139 \text { serotypes }\end{array}$ & $\begin{array}{l}\text { All humans said to be } \\
\text { susceptible }\end{array}$ & $\begin{array}{l}\text { Wound infections, } \\
\text { malnutrition and } \\
\text { immunosuppression }\end{array}$ & NK & N/A & $\begin{array}{l}\text { brackish waters } \\
\text { where they are part } \\
\text { of the normal flora }\end{array}$ & \begin{tabular}{|l|} 
associated with outbreaks of \\
enteritis. Fluid replacement \\
used.
\end{tabular} \\
\hline Disease & $\begin{array}{l}\begin{array}{l}\text { Infectious agent. } \\
\text { Target organ if any. }\end{array} \\
\end{array}$ & Location & $\begin{array}{l}\text { ICD } 10 \text { entry. } \\
\text { Impact }\end{array}$ & Susceptibility & Special risk factors & Immunity & Vaccines & $\begin{array}{l}\text { Primary reservoir } \\
\text { and vectors }\end{array}$ & Comments, treatment \\
\hline $\begin{array}{l}\text { Bacterial conjunctivitis, pink } \\
\text { eye, sticky eye, and Brazilian } \\
\text { purpuric fever. }\end{array}$ & $\begin{array}{l}\text { Many organisms } \\
\text { can be involved the } \\
\text { most important are } \\
\text { Hemophilus influenzae } \\
\text { and Streptococcus } \\
\text { pneumoniae. Viral causes } \\
\text { dealt with under Viral } \\
\text { Disease heading. } \\
\text { Eyes. }\end{array}$ & $\begin{array}{l}\text { Widespread and } \\
\text { common }\end{array}$ & $\begin{array}{l}\text { A48.4 } \\
\text { Warmer climates } \\
\text { seasonal epidemics } \\
\text { in the main non- } \\
\text { fatal but systemic } \\
\text { fatal disease has } \\
\text { been reported } \\
\text { (Brazilian purpuric } \\
\text { fever) }\end{array}$ & Probably general & $\begin{array}{l}\text { Children under five most } \\
\text { affected. The debilitated and } \\
\text { the aged are particularly } \\
\text { susceptible to staph. Infection. }\end{array}$ & $\begin{array}{l}\text { Low grade after infection } \\
\text { and varies with the } \\
\text { infectious agentClearly } \\
\text { lack of knowledge here }\end{array}$ & N/A & Humans & $\begin{array}{l}\text { Sulfacetamide plus or minus } \\
\text { antibiotics }\end{array}$ \\
\hline
\end{tabular}




\begin{tabular}{|c|c|c|c|c|c|c|c|c|c|}
\hline $\begin{array}{l}\text { Chlamydial conjunctivitis, } \\
\text { inclusion conjunctivitis, } \\
\text { paratrachoma }\end{array}$ & $\begin{array}{l}\text { Chlamydia trachomatis } \\
\text { Eyes. An STD }\end{array}$ & $\begin{array}{l}\text { Sporadic throughout } \\
\text { the world. }\end{array}$ & A 74.0 & ? & $\begin{array}{l}\text { Affects new born infants } \\
\text { otherwise a complication of } \\
\text { genital infection in adults }\end{array}$ & $\begin{array}{l}\text { No evidence of resistance } \\
\text { to reinfection though } \\
\text { severity of disease is } \\
\text { variable } \\
\end{array}$ & N/A & Humans & $\begin{array}{l}\text { Often acquired by infants } \\
\text { during birth process. } \\
\text { Antibiotics }\end{array}$ \\
\hline $\begin{array}{l}\text { Diarrhoea caused by E.coli, } \\
\text { Enterohaemorrhagic strains. } \\
\text { Shiga toxin producing strains. } \\
\text { complex of pathogens }\end{array}$ & $\begin{array}{l}\text { STEC initially Intestine } \\
\text { but can create massive } \\
\text { renal and other } \\
\text { potentially lethal } \\
\text { problems. }\end{array}$ & $\begin{array}{l}\text { Important problems } \\
\text { in N America, } \\
\text { Europe, S Africa, } \\
\text { Japan Australia. }\end{array}$ & $\begin{array}{l}\text { A04.3 Outbreaks } \\
\text { associated with a } \\
\text { variety of poorly } \\
\text { cooked foods }\end{array}$ & $\begin{array}{l}\text { infectious dose is low. } \\
\text { Little is known about } \\
\text { susceptibility or immunity }\end{array}$ & $\begin{array}{l}\text { Old age, achlorhydria and } \\
\text { infants under five. } \\
\text { Diabetics and infants of } \\
\text { infected mothers. }\end{array}$ & None reported & none & $\begin{array}{l}\text { Cattle and perhaps } \\
\text { deer, more rarely } \\
\text { humans }\end{array}$ & $\begin{array}{l}\text { Fluid and electrolyte } \\
\text { replacement. Antibiotic } \\
\text { treatment uncertain and } \\
\text { potentially dangerous. }\end{array}$ \\
\hline $\begin{array}{l}\text { Diarrhoea caused by E.coli, } \\
\text { Enterotoxigenic strains. }\end{array}$ & ETEC & $\begin{array}{l}\text { Primarily in } \\
\text { developing countries }\end{array}$ & $\begin{array}{l}\text { A04.1A major } \\
\text { cause of traveller's } \\
\text { diarrhoea. In } \\
\text { developing countries } \\
\text { multiple infections } \\
\text { of infants occur }\end{array}$ & $\begin{array}{l}\text { Probably universal though it } \\
\text { is not so stated }\end{array}$ & $\begin{array}{l}\text { Less frequent in adults. } \\
\text { Children <4years of age in } \\
\text { developing countries can have } \\
\text { up to } 32 \% \text { mortality. WHO } \\
\text { reports up to } 380,000 \text { deaths } \\
\text { of such children annually. } \\
\text { Contaminated food particular } \\
\text { risk factor. } \\
\end{array}$ & $\begin{array}{l}\text { Serotype specific } \\
\text { immunity is acquired } \\
\text { following infection. } \\
\text { Problem is that there are } \\
\text { so many serotypes }\end{array}$ & none & humans & $\begin{array}{l}\text { Fluid replacement, } \\
\text { rehydration salts. Anti- } \\
\text { microbial agents often } \\
\text { deemed dangerous. }\end{array}$ \\
\hline Disease & \begin{tabular}{|l|} 
Infectious agent. \\
Target organ if any.
\end{tabular} & Location & $\begin{array}{l}\text { ICD } 10 \text { entry. } \\
\text { Impact }\end{array}$ & Susceptibility & Special risk factors & Immunity & Vaccines & $\begin{array}{l}\text { Primary reservoir } \\
\text { and vectors }\end{array}$ & Comments, treatment \\
\hline $\begin{array}{l}\text { Diarrhoea caused by E.coli, } \\
\text { Entero-invasive strains }\end{array}$ & EIEC & $\begin{array}{l}\text { Endemic in } \\
\text { developing countries }\end{array}$ & \begin{tabular}{|l|} 
A04.2 \\
Causes about 1-5\% \\
of cases at visiting \\
treatment centres
\end{tabular} & NK & $\begin{array}{l}\text { Visitors and children in } \\
\text { endemic regions }\end{array}$ & NK & None & Humans & $\begin{array}{l}\text { Fluid replacement. Few } \\
\text { centres treat this somewhat } \\
\text { rarer disease. }\end{array}$ \\
\hline $\begin{array}{l}\text { Diarrhoea caused by E.coli, } \\
\text { enteropathogenic strains }\end{array}$ & EPEC & \begin{tabular}{|l|} 
Oldest recognized \\
form of largely infant \\
diarrhoea, largely \\
disappeared from the \\
Western world..
\end{tabular} & $\begin{array}{l}\text { A } 04.0 \\
\text { Still a major problem } \\
\text { in many other places } \\
\text { in the developing } \\
\text { world where fatality } \\
\text { rates can be high }\end{array}$ & $\begin{array}{l}\text { Susceptibility is confined } \\
\text { to young infants but why } \\
\text { is not known. It could } \\
\text { be immunity that is not } \\
\text { established. Experiments } \\
\text { on adults suggest that } \\
\text { immunity is the answer. }\end{array}$ & $\begin{array}{l}\text { Disease uncommon in breast } \\
\text { fed infants. Often associated } \\
\text { with contaminated infant } \\
\text { formula. Outbreaks due to } \\
\text { contaminated water or rice } \\
\text { have been reported. }\end{array}$ & Likely but not certain & None & Humans & Fluid replacement \\
\hline $\begin{array}{l}\text { Intestinal E.coli infections and } \\
\text { others }\end{array}$ & EAEC, DAEC & \begin{tabular}{|l|} 
Cause of sporadic out \\
breaks associated with \\
acute and persistent \\
diarrhoea in infants. \\
In developing and \\
developed countries. \\
\end{tabular} & \begin{tabular}{|l|} 
A04.4 \\
EAEC can bea \\
cause of traveller's \\
diarrhoeain as many \\
as $20 \%$ o cases in \\
some reports. \\
\end{tabular} & $\begin{array}{l}\text { DAEC in some reports more } \\
\text { pathogenic in children but } \\
\text { information is sparse. }\end{array}$ & Contaminated food and drink. & Infants are susceptible. & NK & \begin{tabular}{|l} 
Likely humans \\
possibly animals
\end{tabular} & $\begin{array}{l}\text { Rehydration treatment and } \\
\text { anti-microbials are said to } \\
\text { be useful. }\end{array}$ \\
\hline Disease & \begin{tabular}{|l|} 
Infectious agent. \\
Target organ if any. \\
\end{tabular} & Location & $\begin{array}{l}\text { ICD } 10 \text { entry. } \\
\text { Impact }\end{array}$ & Susceptibility & Special risk factors & Immunity & Vaccines & $\begin{array}{l}\text { Primary reservoir } \\
\text { and vectors }\end{array}$ & Comments, treatment \\
\hline Diphtheria & $\begin{array}{l}\text { Corynebacterium } \\
\text { diphtheria } \\
\text { Mucous membranes } \\
\text { of upper respiratory } \\
\text { tract, more rarely other } \\
\text { mucous membranes. A } \\
\text { potent exotoxin causes } \\
\text { the problems. Carried } \\
\text { by some strains of Co- } \\
\text { rynebacteriathemselves } \\
\text { infected with the toxin } \\
\text { generating phage. }\end{array}$ & $\begin{array}{l}\text { A disease of colder } \\
\text { months in temperate } \\
\text { climes }\end{array}$ & $\begin{array}{l}\text { A36 } \\
\text { Major outbreaks } \\
\text { have occurred } \\
\text { in a number of } \\
\text { areas of the world } \\
\text { in recent years } \\
\text { in unvaccinated } \\
\text { individuals }\end{array}$ & Not stated & $\begin{array}{l}\text { Infants born to immune } \\
\text { mothers are protected for up } \\
\text { to six months by passively } \\
\text { acquired antibody. }\end{array}$ & $\begin{array}{l}\text { Lifelong immunity is } \\
\text { usually but not always } \\
\text { acquired after infection. } \\
\text { Immunisation with toxoid } \\
\text { also produces lifelong } \\
\text { immunity (non toxigenic } \\
\text { bacteria rarely cause } \\
\text { disease) }\end{array}$ & Very effective & Humans & $\begin{array}{l}\text { Presence of a phage as is true } \\
\text { for some other bacterial spp. } \\
\text { dictates capacity to produce } \\
\text { a toxin that is the main cause } \\
\text { of pathogenesis. Anti toxin + } \\
\text { sometimes antibiotics }\end{array}$ \\
\hline
\end{tabular}




\begin{tabular}{|c|c|c|c|c|c|c|c|c|c|}
\hline helicobacter pylori infection & $\begin{array}{l}\text { Helicobacter pylori } \\
\text { Causes acute and chronic } \\
\text { gastritis. }\end{array}$ & $\begin{array}{l}\text { WorldwideSaid to be } \\
\text { present in } 50 \% \text { of the } \\
\text { human population }\end{array}$ & $\begin{array}{l}\text { K29 usually no } \\
\text { symptoms but for } \\
\text { some gastritis and } \\
\text { gastric Carcinoma } \\
\text { can follow infection }\end{array}$ & $\begin{array}{l}\text { Universal it is supposed. } \\
\text { Increasing prevalence with } \\
\text { increasing age. }\end{array}$ & $\begin{array}{l}\text { Not identified but supposed } \\
\text { that there must be identifiable } \\
\text { risk factors. Lower } \\
\text { socioeconomic status appears } \\
\text { to be associated with higher } \\
\text { prevalence. }\end{array}$ & None recognized & $\begin{array}{l}\text { None presently } \\
\text { available }\end{array}$ & $\begin{array}{l}\text { Humans probably } \\
\text { though it has been } \\
\text { found in other } \\
\text { primates }\end{array}$ & $\begin{array}{l}\text { Treatment with antibiotics } \\
\text { can be successful in } \\
\text { reducing gastritis stopping } \\
\text { continuation to malignancy. } \\
\text { Controversial antibiotics }\end{array}$ \\
\hline $\begin{array}{l}\text { Ehrlichiosis, } \\
\text { Anaplasmosis, Senetsu Fever, } \\
\text { Neoehrlichosis }\end{array}$ & \begin{tabular}{|l} 
Ehrlichiasennetsu \\
Anaplasmacytophylum \\
Neorickettsiasenesu, \\
Neoehrlichiamisurensis \\
Acute febrile illnesses \\
with small intracellular \\
bacteria that survive \\
inside a variety of \\
phagocytic white blood \\
cells. \\
\end{tabular} & \begin{tabular}{|l} 
Four diseases \\
here one Sennetsu \\
fever the other \\
threedifferent forms \\
of ehrlichiosis. \\
Distribution mainly \\
in north and south \\
America, Europe, \\
Western Japan and \\
Malaysia \\
\end{tabular} & $\begin{array}{l}\text { A79.8 } \\
\text { Range from mild } \\
\text { illnesses to severe } \\
\text { life-threatening } \\
\text { disease. Diagnosis } \\
\text { tricky to differentiate } \\
\text { it from other viral } \\
\text { illnesses. }\end{array}$ & General & $\begin{array}{l}\text { Older, debilitated, or } \\
\text { immunosuppressed people } \\
\text { more susceptible }\end{array}$ & NK & $\begin{array}{l}\text { Re-infection rare. } \\
\text { implication is derived } \\
\text { adaptive immunity. } \\
\text { Consumption of raw } \\
\text { fish suspected cause } \\
\text { with Senetsu fever }\end{array}$ & $\begin{array}{l}\text { Not certain but a } \\
\text { variety of vertebrate } \\
\text { hosts are involved. } \\
\text { Ticks can be vectors. }\end{array}$ & Doxycycline \\
\hline Disease & $\begin{array}{l}\text { Infectious agent. } \\
\text { Target organ if any. }\end{array}$ & Location & $\begin{array}{l}\text { ICD } 10 \text { entry. } \\
\text { Impact }\end{array}$ & Susceptibility & Special risk factors & Immunity & Vaccines & $\begin{array}{l}\text { Primary reservoir } \\
\text { and vectors }\end{array}$ & Comments, treatment \\
\hline $\begin{array}{l}\text { Gonococcal infection, } \\
\text { (a separate category of } \\
\text { gonococcal conjunctivitis is } \\
\text { here ignored), clap, strain, } \\
\text { gleet, dose, G.C. }\end{array}$ & $\begin{array}{l}\text { Neisseria gonorrhoeae } \\
\text { STD particularly in the } \\
\text { commercial sector. }\end{array}$ & Common worldwide & $\begin{array}{l}\text { A54.0 A54.2, Rarely } \\
\text { lethal but with } \\
\text { many unpleasant } \\
\text { symptoms }\end{array}$ & General & Not given & $\begin{array}{l}\text { Humoral and } \\
\text { secretoryantibodieshave } \\
\text { been demonstrated but the } \\
\text { bacterium is antigenically } \\
\text { heterogeneous and } \\
\text { reinfection is common } \\
\end{array}$ & none & $\begin{array}{l}\text { Strictly a human } \\
\text { disease }\end{array}$ & $\begin{array}{l}\text { Major STD. Antibiotics but } \\
\text { many resistant plasmids } \\
\text { exist. }\end{array}$ \\
\hline $\begin{array}{l}\text { Granuloma inguinale } \\
\text { (Donovan osis) }\end{array}$ & $\begin{array}{l}\text { Calymmactobacteri- } \\
\text { umgranulomatis } \\
\text { Genitalia in } 90 \% \text { of cases }\end{array}$ & \begin{tabular}{|l|} 
Rare in industrialised \\
countries but even \\
there small occasional \\
epidemics are \\
recorded.
\end{tabular} & \begin{tabular}{|l|} 
A58 \\
Slight fortunately, \\
but cluster outbreaks \\
have been recorded \\
in tropical and semi- \\
tropical countries
\end{tabular} & $\begin{array}{l}\text { Most common in 20-30 year } \\
\text { old males but known also in } \\
1-4 \text { year old children and it } \\
\text { is suggested that non-sexual } \\
\text { transmission can occur. }\end{array}$ & Bought sexual activity & $\begin{array}{l}\text { None it appears, i.e., } \\
\text { second attacks occur } \\
\text { (presumably after } \\
\text { treatment of the first } \\
\text { attack) }\end{array}$ & none & Humans & $\begin{array}{l}\text { Horrid condition not easily } \\
\text { brought under control that } \\
\text { essentially erodes the genital } \\
\text { regions. We are clearly } \\
\text { short of information on the } \\
\text { disease. Antibiotics } \\
\end{array}$ \\
\hline $\begin{array}{l}\text { Legionellosis (there is also } \\
\text { non pneumonic legionellosis, } \\
\text { Pontiac fever, which is here } \\
\text { ignored). Legionnaires disease }\end{array}$ & Various legionellae & $\begin{array}{l}\text { Widespread but } \\
\text { sporadic more } \\
\text { common in summer } \\
\text { and autumn }\end{array}$ & $\begin{array}{l}\text { A } 48 / 1 \\
\text { Regarded as } \\
\text { dangerous case } \\
\text { fatality rate can be } \\
15 \% .\end{array}$ & Age related & \begin{tabular}{|l} 
Males more than females \\
usually in patients over 50 \\
years of age. Patients who \\
smoke or who have diabetes \\
mellitus are at special risk. \\
immunocompromised \\
people especially those on \\
corticosteroids. Infected \\
cooling towers and warm but \\
not hot water
\end{tabular} & $\begin{array}{l}\text { Implication is that there } \\
\text { is an immune response } \\
\text { in that in a few locations } \\
\text { antibodies have been } \\
\text { detected in } 1-20 \% \text { of the } \\
\text { general population. }\end{array}$ & None stated & $\begin{array}{l}\text { Aqueous primarily, } \\
\text { hot water systems } \\
\text { not properly } \\
\text { maintained. }\end{array}$ & $\begin{array}{l}\text { Why is it called legionnaires } \\
\text { disease? Some antibiotics } \\
\text { are effective.Disinfection of } \\
\text { suspected water supplies is } \\
\text { effective. }\end{array}$ \\
\hline
\end{tabular}




\begin{tabular}{|c|c|c|c|c|c|c|c|c|c|}
\hline Disease & \begin{tabular}{|l} 
Infectious agent. \\
Target organ if any.
\end{tabular} & Location & \begin{tabular}{|l|} 
ICD 10entry. \\
Impact
\end{tabular} & Susceptibility & Special risk factors & Immunity & Vaccines & \begin{tabular}{|l|}
$\begin{array}{l}\text { Primary reservoir } \\
\text { and vectors }\end{array}$ \\
\end{tabular} & Comments, treatment \\
\hline $\begin{array}{l}\text { Leprosy (two forms } \\
\text { tuberculoid and lepromatous } \\
\text { of which the latter is more } \\
\text { severe), Hansen's disease. }\end{array}$ & $\begin{array}{l}\text { Mycobacterium leprae } \\
\text { Cannot be grown in } \\
\text { culture. } \\
\text { Chronic disease of the } \\
\text { skin and peripheral } \\
\text { nerves. }\end{array}$ & $\begin{array}{l}\text { Chief endemic areas } \\
\text { are S and S Eastern } \\
\text { Asia, Indonesia, } \\
\text { tropical Africa } \\
\text { and parts of Latin } \\
\text { America. }\end{array}$ & \begin{tabular}{|l|} 
A30 \\
Over a million cases \\
worldwide but it \\
should be stressed \\
that probably only \\
a small proportion \\
of those infected \\
develop symptoms.
\end{tabular} & \begin{tabular}{|l} 
Rate of lepromin positive \\
tests increases with age \\
but as this can give false \\
positives it is not clear that \\
this represents a build-up of \\
asymptomatic infections.
\end{tabular} & $\begin{array}{l}\text { Inchildhood, rarely seen under } \\
\text { three. Incubation time can be } \\
\text { anything from nine months to } \\
\text { twenty years! }\end{array}$ & $\begin{array}{l}\text { Immunity said to depend } \\
\text { on a cell mediated } \\
\text { response though } \\
\text { antibodies are produced. } \\
\text { It is argued that } 95 \% \\
\text { of the population are } \\
\text { naturally immune. In the } \\
\text { manual this is termed } \\
\text { innate immunity, but this } \\
\text { terminology is probably } \\
\text { incorrect. }\end{array}$ & $\begin{array}{l}\text { BCG may have some } \\
\text { use in this context! }\end{array}$ & $\begin{array}{l}\text { Humans and } \\
\text { armadillos. }\end{array}$ & $\begin{array}{l}\text { Still a major disease not } \\
\text { easily cured. Prolonged } \\
\text { treatment with a variety of } \\
\text { antibiotics but resistance is } \\
\text { a problem. }\end{array}$ \\
\hline $\begin{array}{l}\text { Leptospirosis, Weil's Disease, } \\
\text { Swineherd fever, mud fever, } \\
\text { Haemorrhagic jaundiceand } \\
\text { other names. }\end{array}$ & $\begin{array}{l}\text { Organisms from the } \\
\text { genus Leptospira. Large } \\
\text { number of serotypes. } \\
\text { First phase of infection } \\
\text { can be high fever. Second } \\
\text { phase coincident in time } \\
\text { with development of } \\
\text { antibodies Recovery of } \\
\text { untreated cases can take } \\
\text { several months. }\end{array}$ & $\begin{array}{l}\text { Worldwideexcept } \\
\text { polar regions. Most } \\
\text { prevalent in tropical } \\
\text { and sub-tropical } \\
\text { regions. }\end{array}$ & \begin{tabular}{|l|} 
A27 \\
Asymptomatic or \\
mild infections \\
are common but \\
occasional epidemics \\
have killed many \\
of those infected. \\
In general 5-10\% \\
of cases progress to \\
severe illness. \\
\end{tabular} & general & $\begin{array}{l}\text { Case fatality rate is generally } \\
\text { low but can reach twenty } \\
\text { percent in those with } \\
\text { renal damage. Largely an } \\
\text { occupational disease for those } \\
\text { working in sugar plantations } \\
\text { and rice fields Often a disease } \\
\text { of bathers and campers no } \\
\text { other predilections given }\end{array}$ & $\begin{array}{l}\text { Serovar specific immunity } \\
\text { arises }\end{array}$ & $\begin{array}{l}\text { In both workers at risk } \\
\text { and the local domestic } \\
\text { animals this has been } \\
\text { attempted. The results } \\
\text { are either not known } \\
\text { or simply not given }\end{array}$ & $\begin{array}{l}\text { Wide variety of } \\
\text { wild and domestic } \\
\text { animals. }\end{array}$ & $\begin{array}{l}\text { Prompt specific, early } \\
\text { treatment with antibiotics } \\
\text { can be effective. }\end{array}$ \\
\hline Disease & $\begin{array}{l}\text { Infectious agent. } \\
\text { Target organ if any. }\end{array}$ & Location & $\begin{array}{l}\text { ICD 10entry. } \\
\text { Impact }\end{array}$ & Susceptibility & Special risk factors & Immunity & Vaccines & $\begin{array}{l}\text { Primary reservoir } \\
\text { and vectors }\end{array}$ & Comments, treatment \\
\hline Listeriosis & $\begin{array}{l}\text { Listeria monocytogenes } \\
\text { Can present as an } \\
\text { invasive disease with } \\
\text { septicaemia and } \\
\text { meningitis. }\end{array}$ & \begin{tabular}{l|} 
Uncommonly \\
diagnosed infection \\
in USA but frequency \\
elsewhere in the \\
world not given. \\
Outbreak cases are \\
reported associated \\
with contaminated \\
food.
\end{tabular} & \begin{tabular}{|l|} 
A32 \\
Accounts for a \\
small fraction of \\
all blood borne \\
diseases. Despite this \\
it is regarded as an \\
important cause of \\
severe illness.
\end{tabular} & $\begin{array}{l}\text { Most childrenand young } \\
\text { adults are resistant }\end{array}$ & $\begin{array}{l}\text { Adults over the age of } 40 \\
\text { become more sensitive and } \\
\text { Almost all the debilitating } \\
\text { and immunosuppressive } \\
\text { conditions, (including } \\
\text { pregnancy)confer heightened } \\
\text { sensitivity }\end{array}$ & NK & None & $\begin{array}{l}\text { Solid forage water } \\
\text { mud and silage plus } \\
\text { domestic animals } \\
\text { and asymptomatic } \\
\text { human (faecal) } \\
\text { shedders. }\end{array}$ & $\begin{array}{l}\text { Commonly associated with } \\
\text { manufacture of soft cheeses } \\
\text { of which it is part of the } \\
\text { bacterial array. Antibiotics } \\
\text { work }\end{array}$ \\
\hline $\begin{array}{l}\text { Lyme disease, Lyme borreiosis, } \\
\text { tickborne meningopoly } \\
\text { neuritis }\end{array}$ & $\begin{array}{l}\text { Boreliaburgdoreferi and } \\
\text { others } \\
\text { Distinctive skin lesions } \\
\text { and a variety of other } \\
\text { systemic manifestations } \\
\text { over a long time. }\end{array}$ & $\begin{array}{l}\text { Found in many places } \\
\text { particularly well } \\
\text { known in USA but } \\
\text { also in Europe, China } \\
\text { and Japan }\end{array}$ & $\begin{array}{l}\text { A69.2, L90.4Difficult } \\
\text { to say on evidence } \\
\text { presented. Clearly } \\
\text { an uncomfortable } \\
\text { and chronic disease } \\
\text { that can usually be } \\
\text { successfully treated, }\end{array}$ & Universal apparently & None stated & $\begin{array}{l}\text { Re-infection has occurred } \\
\text { in those treated early with } \\
\text { antibiotics, the implication } \\
\text { is either that immunity is } \\
\text { not a result of infection or } \\
\text { that antibiotic treatment } \\
\text { prevents the development } \\
\text { of lasting immunity. }\end{array}$ & $\begin{array}{l}\text { Vaccines have been } \\
\text { developed and used } \\
\text { with up to } 76 \% \\
\text { success, but this is not } \\
\text { a clear story. }\end{array}$ & \begin{tabular}{|l} 
Disease is \\
maintained in \\
an enzootic \\
transmission cycle \\
that involves ixodid \\
ticks wild rodents \\
and deer.
\end{tabular} & $\begin{array}{l}\text { A zoonosisTreatment with } \\
\text { antibiotics }\end{array}$ \\
\hline
\end{tabular}




\begin{tabular}{|c|c|c|c|c|c|c|c|c|c|}
\hline Disease & \begin{tabular}{|l|} 
Infectious agent. \\
Target organ if any.
\end{tabular} & Location & $\begin{array}{l}\text { ICD } 10 \text { entry. } \\
\text { Impact }\end{array}$ & Susceptibility & Special risk factors & Immunity & Vaccines & $\begin{array}{l}\text { Primary reservoir } \\
\text { and vectors }\end{array}$ & Comments, treatment \\
\hline $\begin{array}{l}\text { Lymphogranuloma venereum, } \\
\text { climatic or tropical bubo }\end{array}$ & $\begin{array}{l}\text { Chlamydia trachomatis } \\
\text { genotypes. } \\
\text { STD in both sexes. } \\
\text { In men who have sex } \\
\text { with men proctitis can } \\
\text { develop. }\end{array}$ & $\begin{array}{l}\text { Worldwide especially } \\
\text { in the tropical and } \\
\text { subtropical areas }\end{array}$ & $\begin{array}{l}\text { A55 } \\
\text { Disease untreated is } \\
\text { debilitating but not } \\
\text { usually fatal. }\end{array}$ & General & Male homosexuals & Not clear & None & $\begin{array}{l}\text { Humans often } \\
\text { asymptomatic } \\
\text { females. }\end{array}$ & Antibiotics can be effective. \\
\hline $\begin{array}{l}\text { Melioidosis, Whitmore disease } \\
\text { Glanders }\end{array}$ & $\begin{array}{l}\text { Burkholderiapseudomal- } \\
\text { leicausative agent for Me- } \\
\text { lioiodosis,Burkholderia } \\
\text { mallei for Glanders. } \\
\text { Cutaneous or visceral } \\
\text { abscesses with } \\
\text { subsequent development } \\
\text { of a wide range of } \\
\text { potentially lethal } \\
\text { systemic symptoms. } \\
\end{array}$ & $\begin{array}{l}\text { A significant cause of } \\
\text { community acquired } \\
\text { sepsis in the tropics. }\end{array}$ & $\begin{array}{l}\text { A24.1, A24.4, A24.0 } \\
\text { In a number of } \\
\text { largely tropical } \\
\text { places }\end{array}$ & $\begin{array}{l}\text { Problem here of definition. } \\
\text { Disease is uncommon even } \\
\text { in parts of the world where } \\
\text { the infective organism exists } \\
\text { and the (rural) population } \\
\text { are in frequent contact } \\
\text { with the soil in which } \\
\text { the bacterium exists. The } \\
\text { implication is that infection } \\
\text { is common disease is rare } \\
\end{array}$ & $\begin{array}{l}\text { Those with abraded or burned } \\
\text { skin who also have intimate } \\
\text { contact with soil }\end{array}$ & $\begin{array}{l}\text { Not clear. Change } \\
\text { of environment, e.g. } \\
\text { development of diabetes } \\
\text { mellitus can give } \\
\text { recrudescence of what } \\
\text { is probably a long term } \\
\text { latent infection }\end{array}$ & None & \begin{tabular}{|l|} 
Soil and water. A \\
saprophyte. Various \\
animals can become \\
infected but there are \\
no known vectors to \\
which they transfer \\
the organism but \\
they canspread it \\
around passively \\
\end{tabular} & $\begin{array}{l}\text { TMP-SMX iseffective } \\
\text { treatment ( a mixture } \\
\text { of trimethoprim and } \\
\text { sulphamethoxazole) }\end{array}$ \\
\hline Meningitis, cerebrospinal fever & $\begin{array}{l}\text { Neisseria } \\
\text { menigitidisvarious strains/ } \\
\text { serotypes that define } \\
\text { different epidemics } \\
\text { Inflammation of the } \\
\text { meninges is the defining } \\
\text { feature of this disease and } \\
\text { here three bacterial causes } \\
\text { of the condition will be } \\
\text { considered. A petechial } \\
\text { rash often present in } \\
\text { Europe and N.America } \\
\text { but rarely in Africa. } \\
\end{array}$ & Ubiquitous & $\begin{array}{l}\text { A39.0 } \\
\text { Nowadays in } \\
\text { developed country } \\
\text { case-fatality rate is } \\
8-15 \% .5-10 \% \text { of } \\
\text { those in endemic } \\
\text { countries may } \\
\text { be asymptomatic } \\
\text { carriers of whom } \\
\text { very few progress to } \\
\text { disease. }\end{array}$ & \begin{tabular}{|l|} 
Susceptibility to disease \\
is low and decreases with \\
age. Disease is primarily of \\
young children and young \\
adults. More common in \\
males than in females. \\
Highest burden of diseasein \\
African meningeal belt.
\end{tabular} & $\begin{array}{l}\text { Splenectomy, certain } \\
\text { complement components }\end{array}$ & $\begin{array}{l}\text { Group specific immunity } \\
\text { of unknown duration } \\
\text { follows even sub clinical } \\
\text { infection }\end{array}$ & $\begin{array}{l}\text { Dead vaccines are } \\
\text { available and have } \\
\text { been reasonably } \\
\text { successfully applied }\end{array}$ & Humans & $\begin{array}{l}\text { Epidemics tend to crop up } \\
\text { in those inhabiting crowded } \\
\text { communal quarters. A } \\
\text { variety of antibiotics can be } \\
\text { effective treatment. }\end{array}$ \\
\hline Disease & $\begin{array}{l}\text { Infectious agent. } \\
\text { Target organ if any. }\end{array}$ & Location & $\begin{array}{l}\text { ICD } 10 \text { entry. } \\
\text { Impact }\end{array}$ & Susceptibility & Special risk factors & Immunity & Vaccines & $\begin{array}{l}\text { Primary reservoir } \\
\text { and vectors }\end{array}$ & Comments, treatment \\
\hline Hemophilus meningitis, & \begin{tabular}{|l} 
Hemophilus influenza In \\
industrialised countries \\
before widespread \\
use of Hib conjugate, \\
vaccines meningitis \\
was the most common \\
presentation,epiglottitis, \\
and bacteremia were \\
the next most common. \\
In developing countries \\
lower respiratory tract \\
infection was the most \\
common first symptom. \\
Pneumonia of this kind \\
has been said to cause \\
480,000 deaths per year \\
among children under five \\
years of age. \\
\end{tabular} & Worldwide & $\begin{array}{l}\text { G00.0 } \\
\text { Most prevalent } \\
\text { among children } \\
\text { three months to } \\
\text { three years. Vaccine } \\
\text { use has cut down } \\
\text { the disease in the } \\
\text { USA and a higher } \\
\text { proportion of cases } \\
\text { is now seen in adults }\end{array}$ & Universal & Age & $\begin{array}{l}\text { Immunity usually } \\
\text { associated with presence } \\
\text { of circulating anti-capsular } \\
\text { antibodies acquired } \\
\text { transplacentally or by } \\
\text { immunisation. Or a prior } \\
\text { infection }\end{array}$ & $\begin{array}{l}\text { Yes, with } \\
\text { polysaccharides }\end{array}$ & Humans & $\begin{array}{l}\text { Antibiotics but resistance is } \\
\text { now a problem. }\end{array}$ \\
\hline
\end{tabular}




\begin{tabular}{|c|c|c|c|c|c|c|c|c|c|}
\hline Disease & \begin{tabular}{|l|} 
Infectious agent. \\
Target organ if any.
\end{tabular} & Location & \begin{tabular}{|l|} 
ICD 10 entry. \\
Impact
\end{tabular} & Susceptibility & Special risk factors & Immunity & Vaccines & $\begin{array}{l}\text { Primary reservoir } \\
\text { and vectors }\end{array}$ & Comments, treatment \\
\hline $\begin{array}{l}\text { Nocardiosis, } \\
\text { Actinomycetoma }\end{array}$ & $\begin{array}{l}\text { Nocardiaasteroidsand } \\
\text { others of that } \\
\text { ilkPulmonary infection }\end{array}$ & $\begin{array}{l}\text { Occasional sporadic } \\
\text { disease in all parts of } \\
\text { the world }\end{array}$ & $\begin{array}{l}\text { B47.1 } \\
\text { Difficult to say on } \\
\text { evidence presented }\end{array}$ & Unknown & $\begin{array}{l}\text { Endogenous or iatrogenic } \\
\text { adrenal hypercorticism and } \\
\text { probably primary alveolar } \\
\text { proteinosis }\end{array}$ & \begin{tabular}{|l|} 
Opportunistic \\
infection can occur in \\
immunosuppressed \\
individuals. Implication \\
is that there is an immune \\
mechanism. \\
\end{tabular} & None & $\begin{array}{l}\text { A saprophyte found } \\
\text { in soil, water and } \\
\text { organic material. }\end{array}$ & $\begin{array}{l}\text { TMP-SMX depending on } \\
\text { serotyope specificity. }\end{array}$ \\
\hline $\begin{array}{l}\text { Pertussis, Whooping cough } \\
\text { Parapertussis, a milder version } \\
\text { of the disease }\end{array}$ & \begin{tabular}{|l|} 
Bordetellapertussis \\
Bordetella parapertussis. \\
A respiratory disease \\
with occasional systemic \\
complications.
\end{tabular} & $\begin{array}{l}\text { An endemic disease } \\
\text { common especially } \\
\text { young children } \\
\text { everywhere }\end{array}$ & \begin{tabular}{|l|} 
A37.0, A37.9 \\
A37.1Schemes \\
of immunisation \\
have reduced the \\
prevalence. This \\
disease is still \\
among the most \\
lethal of all the \\
childhood diseases. \\
In recent years \\
it is increasingly \\
recognized in older \\
children and adults \\
even when they have \\
been immunized as \\
infants. \\
\end{tabular} & $\begin{array}{l}\text { Universal among non- } \\
\text { immunised individuals. } \\
\text { Milder and atypical cases } \\
\text { occur in all groups (the } \\
\text { hundred day cough!) }\end{array}$ & \begin{tabular}{|l|} 
Malnutrition and enteric \\
infections can be predisposing \\
conditions. Interestingly, \\
transplacental transfer of \\
immunity has never been \\
demonstrated. Note comment \\
in Vaccines column.
\end{tabular} & $\begin{array}{l}\text { One attack usually confers } \\
\text { prolonged immunity } \\
\text { although second attacks } \\
\text { can occur. }\end{array}$ & \begin{tabular}{|l|} 
A killed vaccine \\
is widely used. \\
Maternal antibodies \\
are carried across \\
the placenta which \\
observation has led \\
several countries to \\
adopt immunisation \\
prior to pregnancy \\
but whether this \\
stratagem works is not \\
stated.
\end{tabular} & Humans & $\begin{array}{l}\text { ? Erythromycin reduces the } \\
\text { period of communicability } \\
\text { but does not affect } \\
\text { symptoms except when } \\
\text { given early. }\end{array}$ \\
\hline Disease & $\begin{array}{l}\text { Infectious agent. } \\
\text { Target organ if any. }\end{array}$ & Location & $\begin{array}{l}\text { ICD } 10 \text { entry. } \\
\text { Impact }\end{array}$ & Susceptibility & Special risk factors & Immunity & Vaccines & \begin{tabular}{|l|} 
Primary reservoir \\
and vectors
\end{tabular} & Comments, treatment \\
\hline Pinta, Carate & $\begin{array}{l}\text { Treponema caroteum a } \\
\text { spirochaete. A chronic } \\
\text { non venereal skin } \\
\text { disease. }\end{array}$ & \begin{tabular}{|l|} 
Found only among \\
crowded rural \\
populations living in \\
poor conditions in the \\
American tropics
\end{tabular} & $\begin{array}{l}\text { A67 } \\
\text { Physical disability } \\
\text { does not occur. } \\
\text { Organ systems } \\
\text { are not involved } \\
\text { Not fatal. Said to } \\
\text { be on its way to } \\
\text { eradication! }\end{array}$ & $\begin{array}{l}\text { Not defined presumably as } \\
\text { in other treponematoses } \\
\text { (various syphilitic diseases } \\
\text { in relation to which } \\
\text { immunity can develop) }\end{array}$ & Mainly a disease of children & Not stated & None & $\begin{array}{l}\text { Humans. Various } \\
\text { biting flies are } \\
\text { suspected of being } \\
\text { vectors. }\end{array}$ & $\begin{array}{l}\text { A none-venereal disease. } \\
\text { Antibiotics fix it. }\end{array}$ \\
\hline Plague, Pestis & $\begin{array}{l}\text { Yersinia pestis } \\
\text { Three presentations, } \\
\text { bubonic, pneumonic and } \\
\text { septicaemic. }\end{array}$ & \begin{tabular}{|l|} 
Almost everywhere \\
that there are wild \\
rodents. \\
Foci of infection \\
exist in the Americas \\
particularly in \\
N.Eastern Brazil.
\end{tabular} & \begin{tabular}{|l|} 
A20 \\
Both bubonic and \\
pneumonic forms \\
can be lethal and \\
in the past have \\
been responsible \\
for major epidemic \\
mortality. Untreated \\
the mortality rate is \\
$50-60 \%$ These days \\
it is clearly less of a \\
problem than it was.
\end{tabular} & General & None given & $\begin{array}{l}\text { Some immunity after } \\
\text { recovery. }\end{array}$ & $\begin{array}{l}\text { Yes both living and } \\
\text { dead. They can be } \\
\text { efficient for about } \\
\text { three months }\end{array}$ & $\begin{array}{l}\text { Wild Rats with their } \\
\text { fleas as the vector. }\end{array}$ & $\begin{array}{l}\text { A potential terrorist weapon. } \\
\text { Streptomycin is the drug of } \\
\text { choice. The pathogenicity is } \\
\text { associated with a mutation. } \\
\text { P. Unusual example of } \\
\text { a mutation conferring } \\
\text { increased pathogenesis. }\end{array}$ \\
\hline
\end{tabular}




\begin{tabular}{|c|c|c|c|c|c|c|c|c|c|}
\hline Disease & \begin{tabular}{|l|} 
Infectious agent. \\
Target organ if any.
\end{tabular} & Location & $\begin{array}{l}\text { ICD } 10 \text { entry. } \\
\text { Impact }\end{array}$ & Susceptibility & Special risk factors & Immunity & Vaccines & $\begin{array}{l}\text { Primary reservoir } \\
\text { and vectors }\end{array}$ & Comments, treatment \\
\hline $\begin{array}{l}\text { Pneumonia, many organisms } \\
\text { can cause pneumonia. Here } \\
\text { only four will be dealt with } \\
\text { 1,pneumococcal pneumonia }\end{array}$ & $\begin{array}{l}\text { Streptococcus pneumoniae } \\
\text { (twenty-three capsular } \\
\text { types account for ninety } \\
\text { per cent of the infections } \\
\text { that cause bacterial } \\
\text { pneumonia in the USA) } \\
\text { Often sudden onset high } \\
\text { fever with a wide variety } \\
\text { of complications. }\end{array}$ & \begin{tabular}{|l|} 
Essentially worldwide \\
though increasing \\
control was \\
being developed. \\
Now resistance \\
to antibiotics is \\
becoming a problem.
\end{tabular} & $\begin{array}{l}\text { J13 } \\
\text { A major cause of } \\
\text { death in developing } \\
\text { countries among } \\
\text { newborn children. } \\
\text { The disease can } \\
\text { be associated with } \\
\text { influenza infection. }\end{array}$ & $\begin{array}{l}\text { General in the sense that } \\
\text { I suspect the organism } \\
\text { concerned is always present. } \\
\text { Not general in the sense that } \\
\text { only few get the disease! The } \\
\text { definition of susceptibility is } \\
\text { here strained. }\end{array}$ & $\begin{array}{l}\text { In young infants the mortality } \\
\text { even using antibiotics can be } \\
60 \% \text {, malnutrition and low } \\
\text { birth weight are contributory } \\
\text { factors. Any harm to the } \\
\text { lower respiratory tract is } \\
\text { predisposing. In adults } \\
\text { almost any co-morbidity can } \\
\text { predispose. }\end{array}$ & $\begin{array}{l}\text { Serotype specific } \\
\text { immunity can be long } \\
\text { lasting. }\end{array}$ & $\begin{array}{l}\text { A vaccine with all } \\
23 \text { capsular types is } \\
\text { available, it is not } \\
\text { effective in children } \\
\text { under the age of } 2 \\
\text { but it can be useful } \\
\text { prophylaxis in the } \\
\text { elderly }\end{array}$ & $\begin{array}{l}\text { Humans (many } \\
\text { normal individuals } \\
\text { have the organism } \\
\text { concerned as part } \\
\text { of their respiratory } \\
\text { tract flora.) }\end{array}$ & $\begin{array}{l}\text { Splenectomy is a } \\
\text { predisposing factor. } \\
\text { Antibiotic resistance now } \\
\text { common. }\end{array}$ \\
\hline $\begin{array}{l}\text { Pneumonia, primary atypical } \\
\text { pneumonia }\end{array}$ & $\begin{array}{l}\text { Mycoplasma pneumoniae } \\
\text { The taxonomic } \\
\text { designation of this } \\
\text { organism is uncertain } \\
\text { being either virus or } \\
\text { bacterium. Here it is } \\
\text { included among the } \\
\text { bacterial causes. }\end{array}$ & $\begin{array}{l}\text { Worldwide sporadic } \\
\text { and epidemic }\end{array}$ & $\begin{array}{l}\text { J15.7 } \\
\text { Fatalities rare, } \\
\text { differential diagnosis } \\
\text { difficult there being } \\
\text { at least ten other } \\
\text { infectious causes of } \\
\text { pneumonia! Clinical } \\
\text { disease occurs in } \\
\text { 3-30\% of infections }\end{array}$ & $\begin{array}{l}\text { Susceptibility not } \\
\text { mentioned! }\end{array}$ & None given & $\begin{array}{l}\text { Second infections } \\
\text { do occur. Immunity } \\
\text { correlated with antibodies } \\
\text { that can remain for a while }\end{array}$ & None & Humans & $\begin{array}{l}\text { Impression given is of an } \\
\text { occasional infection that } \\
\text { elicits only little immunity } \\
\text { perhaps because the causal } \\
\text { organism simply does not } \\
\text { really like it in man. There } \\
\text { are many species that infect } \\
\text { domestic animals but there } \\
\text { is no record here of zoonotic } \\
\text { infection. Antibiotics work. }\end{array}$ \\
\hline Disease & \begin{tabular}{|l|} 
Infectious agent. \\
Target organ if any. \\
\end{tabular} & Location & $\begin{array}{l}\text { ICD } 10 \text { entry. } \\
\text { Impact }\end{array}$ & Susceptibility & Special risk factors & Immunity & Vaccines & $\begin{array}{l}\text { Primary reservoir } \\
\text { and vectors }\end{array}$ & Comments, treatment \\
\hline $\begin{array}{l}\text { Pneumonia, neonatal } \\
\text { eosinophilic pneumonia, } \\
\text { Congenital pneumonia due to } \\
\text { Chlamydia }\end{array}$ & $\begin{array}{l}\text { Chlamydia trachomatis } \\
\text { various immunotypes } \\
\text { A sub-acute pulmonary } \\
\text { disease }\end{array}$ & \begin{tabular}{|l|} 
Probably coincides \\
with the worldwide \\
distribution of the \\
causative organism as \\
a genitally transmitted \\
infection \\
\end{tabular} & $\begin{array}{l}\text { P23.1 } \\
\text { Illness usually } \\
\text { moderate }\end{array}$ & ? & $\begin{array}{l}\text { Infants born to mothers } \\
\text { who have chlamydial genital } \\
\text { infection. }\end{array}$ & $\begin{array}{l}\text { Unknown. Maternal } \\
\text { antibody is not protective }\end{array}$ & None & Humans & Oral erythromycin. \\
\hline $\begin{array}{l}\text { Pneumonia } \\
\text { pneumonia due to Chlamydia }\end{array}$ & $\begin{array}{l}\text { Chlamydia pneumoniae } \\
\text { An acute respiratory } \\
\text { disease. }\end{array}$ & $\begin{array}{l}\text { Presumably } \\
\text { worldwide }\end{array}$ & $\begin{array}{l}J 16.0 \\
\text { Death rare in } \\
\text { uncomplicated cases }\end{array}$ & Universal & $\begin{array}{l}\text { Increased likelihood of clinical } \\
\text { disease withpre-existing } \\
\text { chronic disease. }\end{array}$ & $\begin{array}{l}\text { Some suggestion of immunity after infection } \\
\text { however second episodes of preumonia are } \\
\text { not unusual }\end{array}$ & None & Humans probably & Oral tetracyclines \\
\hline $\begin{array}{l}\text { Psittacosis, Ornithosis, Parrot } \\
\text { fever, Avian Chlamydiosis. }\end{array}$ & $\begin{array}{l}\text { Chlamydophilapsittaci } \\
\text { An acute disease with } \\
\text { systemic presentations } \\
\text { and respiratory } \\
\text { symptoms. }\end{array}$ & World-wide & $\begin{array}{l}\text { A70 } \\
\text { Usually, mild }\end{array}$ & Universal & Exposure to birds and old age & $\begin{array}{l}\text { Immunity after infection } \\
\text { incomplete and transitory }\end{array}$ & none & \begin{tabular}{|l} 
Parakeets, parrots \\
and love birds \\
mainly. Birds that \\
appear healthy can \\
become shedders \\
under conditions of \\
stress. \\
\end{tabular} & \\
\hline Q fever, Query fever. & $\begin{array}{l}\text { Coxiella burnettii } \\
\text { An acute febrile disease. } \\
\text { Various complications } \\
\text { sometimes involving } \\
\text { the liver. }\end{array}$ & $\begin{array}{l}\text { Worldwide, under } \\
\text { reported It should be } \\
\text { noted that fatality in } \\
\text { untreated cases can be } \\
\text { as high as } 2.4 \% \text {. }\end{array}$ & A78 & General & $\begin{array}{l}\text { A variety of occupations } \\
\text { particularly veterinarian and } \\
\text { abattoir workers. are associated } \\
\text { with this disease. }\end{array}$ & \begin{tabular}{|l} 
Immunity probably \\
lifelong after recovery \\
from disease. Cell \\
mediated immunity lasts \\
longer than humoral (does \\
the organismpersist?)
\end{tabular} & $\begin{array}{l}\text { Not commercially } \\
\text { available but for those } \\
\text { at high-risk vaccines } \\
\text { that are effective have } \\
\text { been prepared. }\end{array}$ & $\begin{array}{l}\text { Sheep, cattle., goats } \\
\text { and dogs. }\end{array}$ & $\begin{array}{l}\text { Tetracyclines for acute } \\
\text { disease Antibiotics. }\end{array}$ \\
\hline
\end{tabular}




\begin{tabular}{|c|c|c|c|c|c|c|c|c|c|}
\hline Disease & \begin{tabular}{|l|} 
Infectious agent. \\
Target organ if any.
\end{tabular} & Location & $\begin{array}{l}\text { ICD } 10 \text { entry. } \\
\text { Impact }\end{array}$ & Susceptibility & Special risk factors & Immunity & Vaccines & $\begin{array}{l}\text { Primary reservoir } \\
\text { and vectors }\end{array}$ & Comments, treatment \\
\hline Relapsing fever, & $\begin{array}{l}\text { Borrelia recurrentis } \\
\text { Fever often recurrent. }\end{array}$ & $\begin{array}{l}\text { Worldwide except } \\
\text { Australia and New } \\
\text { Zealand }\end{array}$ & $\begin{array}{l}\text { A68 } \\
\text { Untreated case } \\
\text { fatality canbe } 2-10 \%\end{array}$ & general & None stated & $\begin{array}{l}\text { Unknown but second } \\
\text { attacks are rare. }\end{array}$ & None & \begin{tabular}{|l|} 
Humans and wild \\
rodent. There are \\
some differences \\
between the tick and \\
louse-borne forms of \\
the disease. \\
\end{tabular} & Tetracyclines \\
\hline \begin{tabular}{|l} 
Rickettsioses, tick borne, rocky \\
mountain spotted fever. \\
Some twelve fevers are \\
recorded under this heading, \\
from specific geographical \\
locations, here only two will be \\
dealt with
\end{tabular} & Rickettsia rickettsii & $\begin{array}{l}\text { Throughout USA } \\
\text { andsome S American } \\
\text { states }\end{array}$ & $\begin{array}{l}\text { A77 } \\
\text { Case fatality 13-25\% } \\
\text { ifnot recognized and } \\
\text { treated }\end{array}$ & general & Patients older than 40 & $\begin{array}{l}\text { Immunity not stated in } \\
20^{\text {th }} \text { Edition. In earlier } \\
\text { editions it is stated that } \\
\text { one attack confers life- } \\
\text { time immunity. }\end{array}$ & none & \begin{tabular}{|l|} 
Maintained in \\
nature by ticks can \\
be transferred to \\
for example dogs in \\
which infection is \\
usually subclinical
\end{tabular} & tetracyclines \\
\hline $\begin{array}{l}\text { Rickettsioses, tick borne, } \\
\text { Boutonneuse fever }\end{array}$ & $\begin{array}{l}\text { Rickettsia conori and } \\
\text { related organisms. }\end{array}$ & $\begin{array}{l}\text { Widely distributed in } \\
\text { Africa and India and } \\
\text { Eastern Europe }\end{array}$ & $\begin{array}{l}\text { A77.1 } \\
\text { Mild to severe febrile } \\
\text { illness }\end{array}$ & General & Travellers! & $\begin{array}{l}\text { Immunity not stated in } \\
20^{\text {th }} \text { Edition. }\end{array}$ & None & \begin{tabular}{|l|} 
Ticks and dogs \\
(travellers dogs pick \\
up infected ticks \\
that are taken home \\
with the owners who \\
subsequently acquire \\
the infection.
\end{tabular} & Tetracyclines \\
\hline Disease & \begin{tabular}{|l|} 
Infectious agent. \\
Target organ if any.
\end{tabular} & Location & $\begin{array}{l}\text { ICD } 10 \text { entry. } \\
\text { Impact }\end{array}$ & Susceptibility & Special risk factors & Immunity & Vaccines & $\begin{array}{l}\text { Primary reservoir } \\
\text { and vectors }\end{array}$ & Comments, treatment \\
\hline Salmonellosis, & $\begin{array}{l}\text { Salmonella bongoriand } S \\
\text { enterica } \\
\text { More than } 2000 \\
\text { serotypes are recorded. } \\
\text { Severe enteritis }\end{array}$ & $\begin{array}{l}\text { Worldwide, can occur } \\
\text { in massive epidemics }\end{array}$ & $\begin{array}{l}\text { AA02 } \\
\text { A million cases } \\
\text { reported annually in } \\
\text { the USA alone! Not } \\
\text { usually fatal }\end{array}$ & $\begin{array}{l}\text { General, severity of } \\
\text { condition related to dosage' } \\
\text { of infection. }\end{array}$ & $\begin{array}{l}\text { The young, achlorhydria, AIDS } \\
\text { patients, malnutrition and } \\
\text { other debilitating conditions. }\end{array}$ & None recorded & None available & $\begin{array}{l}\text { Predominantly an } \\
\text { infection of food but } \\
\text { commonly carried } \\
\text { by a wide variety of } \\
\text { animals. }\end{array}$ & $\begin{array}{l}\text { A major disease that only } \\
\text { causes problems in high } \\
\text { concentrationsNo treatment } \\
\text { generally indicated except } \\
\text { rehydration. In the young } \\
\text { and very old antibiotics can } \\
\text { be given. Patients with AIDS } \\
\text { may require lifelong therapy } \\
\end{array}$ \\
\hline Shigellosis, bacillary dysentery & $\begin{array}{l}\text { Shigella various spp. } \\
\text { Distal small intestine and } \\
\text { colon. }\end{array}$ & Worldwide & $\begin{array}{l}\text { A03 } \\
\text { Estimated that } \\
\text { shigellosis } \\
\text { causes14,000 deaths } \\
\text { annually but mild } \\
\text { and asymptomatic } \\
\text { infections occur and } \\
\text { the illness is usually } \\
\text { self-limiting }\end{array}$ & $\begin{array}{l}\text { General, infection can } \\
\text { follow ingestion of a small } \\
\text { no of bacteria. }\end{array}$ & $\begin{array}{l}\text { young and elderly and } \\
\text { debilitated patients of many } \\
\text { kinds. Breast feeding is } \\
\text { protective for young infants. } \\
\text { Homosexual men where } \\
\text { conditions are poor such as } \\
\text { in jails. }\end{array}$ & $\begin{array}{l}\text { Not recorded. Secondary } \\
\text { attack rates can be } \\
\text { up to } 40 \% \text { in specific } \\
\text { households. }\end{array}$ & $\begin{array}{l}\text { Vaccines with some } \\
\text { short-term efficacy } \\
\text { have been deployed. } \\
\text { There is a clear need } \\
\text { for an effective long- } \\
\text { term vaccine. }\end{array}$ & Humans & $\begin{array}{l}\text { A major disease with far too } \\
\text { little said about it. Particularly } \\
\text { the issue of immunity is not } \\
\text { addressed perhaps because } \\
\text { there is not any although } \\
\text { the experimental vaccines } \\
\text { have had some success. } \\
\text { Symptomatic treatment } \\
\text { except in severe cases. } \\
\text { Antibiotics can then work but } \\
\text { there are major and complex } \\
\text { problems with resistance. }\end{array}$ \\
\hline $\begin{array}{l}\text { Staphylococcal diseases in the } \\
\text { community, boils, carbuncles, } \\
\text { sepsis, infected lacerations. }\end{array}$ & $\begin{array}{l}\text { Staphyllococcus aureus } \\
\text { various coagulase } \\
\text { positive strains are } \\
\text { involved,identified } \\
\text { Skin }\end{array}$ & $\begin{array}{l}\text { Worldwide, highest } \\
\text { incidence of disease } \\
\text { where standards of } \\
\text { hygiene are lowest. }\end{array}$ & $\begin{array}{l}\text { L02, B95.6, B } 95.8 \\
\text { A41.0, A } 41.2\end{array}$ & \begin{tabular}{|l|} 
Universal. $20-30 \%$ of general \\
population are nasal carriers \\
of the relevant organisms. \\
Auto-infection responsible \\
for at least two thirds of \\
infection with disease. \\
\end{tabular} & $\begin{array}{l}\text { New-born and all sorts of } \\
\text { generally debilitated patients }\end{array}$ & $\begin{array}{l}\text { Immune mechanisms } \\
\text { said to depend on the } \\
\text { instruments of innate } \\
\text { immunity. }\end{array}$ & None recorded & $\begin{array}{l}\text { Humans more rarely } \\
\text { animals }\end{array}$ & $\begin{array}{l}\text { Local disease does not } \\
\text { warrant treatment. } \\
\text { Treatment of systematized } \\
\text { infection with antibiotics is } \\
\text { undertaken. }\end{array}$ \\
\hline
\end{tabular}




\begin{tabular}{|c|c|c|c|c|c|c|c|c|c|}
\hline Disease & $\begin{array}{l}\text { Infectious agent. } \\
\text { Target organ if any. }\end{array}$ & Location & $\begin{array}{l}\text { ICD } 10 \text { entry. } \\
\text { Impact }\end{array}$ & Susceptibility & Special risk factors & Immunity & Vaccines & $\begin{array}{l}\text { Primary reservoir } \\
\text { and vectors }\end{array}$ & Comments, treatment \\
\hline $\begin{array}{l}\text { Staphylococcal diseases in the } \\
\text { community, boils, carbuncles } \\
\text { sepsis, infected lacerations. }\end{array}$ & $\begin{array}{l}\text { Staphyllococcus aureus } \\
\text { various coagulase } \\
\text { positive strains are } \\
\text { identified. } \\
\text { Skin }\end{array}$ & $\begin{array}{l}\text { Worldwide, highest } \\
\text { incidence of disease } \\
\text { where standards of } \\
\text { hygiene are lowest. }\end{array}$ & $\begin{array}{l}\text { L02, B95.6, B } 95.8 \\
\text { A41.0A 41.2 }\end{array}$ & \begin{tabular}{|l|} 
Universal $20-30 \%$ of general \\
population are nasal carriers \\
of the relevant organisms. \\
Auto-infection responsible \\
for at least two thirds of \\
infection with disease. \\
\end{tabular} & $\begin{array}{l}\text { New-born and all sorts of } \\
\text { generally debilitated patients }\end{array}$ & $\begin{array}{l}\text { Immune mechanisms } \\
\text { said to depend on the } \\
\text { instruments ofinnate } \\
\text { immunity i.e., not } \\
\text { adaptive. }\end{array}$ & None recorded & $\begin{array}{l}\text { Humans more rarely } \\
\text { animals }\end{array}$ & $\begin{array}{l}\text { Local disease does not } \\
\text { warrant treatment. } \\
\text { Treatment of systematized } \\
\text { infection with antibiotics is } \\
\text { undertaken. }\end{array}$ \\
\hline $\begin{array}{l}\text { Staphylococcal diseases, in } \\
\text { hospital nurseries, impetigo } \\
\text { neonatorum, scaled skin } \\
\text { syndrome, abscess of the breast }\end{array}$ & $\begin{array}{l}\text { As above } \\
\text { Impetigo } \\
\text { Skin. }\end{array}$ & $\begin{array}{l}\text { Worldwide } \\
\text { exacerbated by } \\
\text { laxity in hygiene } \\
\text { precautions and } \\
\text { emergence of } \\
\text { antibiotic resistance. } \\
\end{array}$ & $\begin{array}{l}\text { L } 01 \\
\text { Big problem }\end{array}$ & $\begin{array}{l}\text { In the new-born } \\
\text { susceptibility seems to be } \\
\text { universal }\end{array}$ & $\begin{array}{l}\text { Infected infants remain at risk } \\
\text { for the duration of infection } \\
\text { with a pathogenic strain. }\end{array}$ & ? & None & As above & $\begin{array}{l}\text { Antibiotics for both local } \\
\text { and systemic infections can } \\
\text { be effective. }\end{array}$ \\
\hline $\begin{array}{l}\text { Staphylococcal diseases, in } \\
\text { medical and surgical wards. }\end{array}$ & $\begin{array}{l}\text { As above plus the } \\
\text { problem that } 90 \% \text { of the } \\
\text { strains causing problems } \\
\text { are antibiotic resistant } \\
\text { (MRSA). } \\
\text { Awide variety of } \\
\text { conditions including } \\
\text { endocarditis, } \\
\text { osteomyelitis, } \\
\text { pneumonia, meningitis, }\end{array}$ & & $\begin{array}{l}\text { J15.2, M86, M00.0, } \\
\text { 133.0. } \\
\text { Probably the most } \\
\text { serious problem of } \\
\text { hospitals that have } \\
\text { surgery, implants } \\
\text { and so on. }\end{array}$ & Universal? & Any sick people & ? & None & As above & $\begin{array}{l}\text { The organism concerned is } \\
\text { essentially ubiquitous and } \\
\text { seems on the face of it to } \\
\text { elicit little or no immune } \\
\text { response Appropriate } \\
\text { antimicrobials with great } \\
\text { problems of resistance. }\end{array}$ \\
\hline $\begin{array}{l}\text { Streptococcal infection, caused } \\
\text { by group A haemolytic streps, } \\
\text { a large no of diseases including } \\
\text { scarlet fever, sore throat, } \\
\text { erysipelas, puerperal fever, } \\
\text { rheumatic fever necrotising } \\
\text { fasciitis and so on. }\end{array}$ & \begin{tabular}{|l|} 
Streptococcus pyogenes \\
group A \\
A wide variety of \\
conditions mimicking \\
sometimes the conditions \\
caused by Staphylococci.
\end{tabular} & \begin{tabular}{|l|} 
The diseases \\
concerned need \\
separate treatment \\
as they differ in \\
distribution across the \\
world.
\end{tabular} & \begin{tabular}{|l|} 
Again treatment \\
of the diseases as \\
one category is not \\
easy, for example \\
rheumatic fever \\
is much less than \\
it was but in 1985 \\
there were outbreaks \\
in the USA. The \\
highest incidence \\
of impetigo occurs \\
in young children \\
in the late fall and \\
so on.
\end{tabular} & General & None quoted & $\begin{array}{l}\text { For some of the diseases } \\
\text { long lasting type specific } \\
\text { immunity follows } \\
\text { infection for others it } \\
\text { does not. For example, } \\
\text { rheumatic disease has } \\
\text { a significant risk of } \\
\text { recurrence. It seems } \\
\text { that although we are } \\
\text { dealing with the same } \\
\text { basic organism its many } \\
\text { disease manifestations are } \\
\text { relatively ill understood }\end{array}$ & None & Humans & $\begin{array}{l}\text { It seems extraordinary } \\
\text { that such a common set of } \\
\text { diseases should be lumped } \\
\text { together despite clear } \\
\text { differences between them } \\
\text { in terms of mechanisms of } \\
\text { disease. Antibiotics. }\end{array}$ \\
\hline
\end{tabular}




\begin{tabular}{|c|c|c|c|c|c|c|c|c|c|}
\hline Disease & \begin{tabular}{|l|} 
Infectious agent. \\
Target organ if any.
\end{tabular} & Location & $\begin{array}{l}\text { ICD } 10 \text { entry. } \\
\text { Impact }\end{array}$ & Susceptibility & Special risk factors & Immunity & Vaccines & $\begin{array}{l}\text { Primary reservoir } \\
\text { and vectors }\end{array}$ & Comments, treatment \\
\hline $\begin{array}{l}\text { Streptococcal infection, caused } \\
\text { by group A haemolytic streps, } \\
\text { a large no of diseases including } \\
\text { scarlet fever, sore throat, } \\
\text { erysipelas, puerperal fever, } \\
\text { rheumatic fever necrotising } \\
\text { fasciitis and so on. }\end{array}$ & \begin{tabular}{|l|} 
Streptococcus pyogenes \\
group A \\
A wide variety \\
ofconditions mimicking \\
sometimes the conditions \\
caused by Staphylococci.
\end{tabular} & \begin{tabular}{|l|} 
The diseases \\
concerned need \\
separate treatment \\
as they differ in \\
distribution across the \\
world.
\end{tabular} & \begin{tabular}{|l|} 
Again treatment \\
of the diseases as \\
one category is not \\
easy for example \\
rheumatic fever \\
is much less than \\
it was but in 1985 \\
there were outbreaks \\
in the USA. The \\
highest incidence \\
of impetigo occurs \\
in young children \\
in the late fall and \\
so on. \\
\end{tabular} & General & None quoted & $\begin{array}{l}\text { For some of the diseases } \\
\text { long lasting, type specific } \\
\text { immunity follows } \\
\text { infection for others it } \\
\text { does not. For example } \\
\text { rheumatic disease has } \\
\text { a significant risk of } \\
\text { recurrence. It seems } \\
\text { that although we are } \\
\text { dealing with the same } \\
\text { basic organism its many } \\
\text { disease manifestations are } \\
\text { relatively ill understood }\end{array}$ & None & Humans & $\begin{array}{l}\text { It seems extraordinary } \\
\text { that such a common set of } \\
\text { diseases should be lumped } \\
\text { together despite clear } \\
\text { differences between them } \\
\text { in terms of mechanisms of } \\
\text { disease. Antibiotics. }\end{array}$ \\
\hline $\begin{array}{l}\text { Streptococcal infection, caused } \\
\text { by group B, streptococcal } \\
\text { sepsis of the new born. (and } \\
\text { dental caries of the new born), } \\
\text { baby bottle tooth decay. }\end{array}$ & $\begin{array}{l}\text { Streptococcus agalactiae } \\
\text { Serious invasive diseases } \\
\text { of the newborn. } \\
\text { Same as above except } \\
\text { group B }\end{array}$ & & \begin{tabular}{|l} 
P36.0 \\
Thought to occur \\
worldwide. \\
Information here \\
lacking.. Most \\
studies from \\
N.America and \\
Europe \\
\end{tabular} & & $\begin{array}{l}\text { Babies born prematurely, } \\
\text { particularly when there is } \\
\text { rupture of the membranes } \\
\text { more than } 18 \text { hours prior to } \\
\text { delivery. }\end{array}$ & & \begin{tabular}{|l|} 
A vaccine for pregnant \\
women to stimulate \\
antibody production \\
to restrict invasive \\
disease is said to be \\
under production.
\end{tabular} & $\begin{array}{l}\text { Humans. Commonly } \\
\text { found in GI and } \\
\text { urinary tracts. }\end{array}$ & $\begin{array}{l}\text { Anti microbial preparations. } \\
\text { Given particularly to } \\
\text { infected pregnant women } \\
\text { prior to labour. }\end{array}$ \\
\hline Disease & $\begin{array}{l}\text { Infectious agent. } \\
\text { Target organ if any. }\end{array}$ & Location & $\begin{array}{l}\text { ICD } 10 \text { entry. } \\
\text { Impact }\end{array}$ & Susceptibility & Special risk factors & Immunity & Vaccines & $\begin{array}{l}\text { Primary reservoir } \\
\text { and vectors }\end{array}$ & Comments, treatment \\
\hline Syphilis. & $\begin{array}{l}\text { Treponema pallidum } \\
\text { STD. Extremely complex } \\
\text { disease with three } \\
\text { distinct phases. }\end{array}$ & $\begin{array}{l}\text { Widespread among } \\
\text { sexually active } \\
\text { individuals }\end{array}$ & \begin{tabular}{|l|} 
A50-52 Extremely \\
nasty consequences \\
can arises \\
inuntreated chronic \\
disease although \\
latency is known. \\
\end{tabular} & $\begin{array}{l}\text { Universal although only } \\
30 \% \text { of exposures result in } \\
\text { disease. }\end{array}$ & $\begin{array}{l}\text { Immunosuppression, } \\
\text { particularly HIV }\end{array}$ & $\begin{array}{l}\text { Immunity to re- or } \\
\text { further- infection usually } \\
\text { develops in time but } \\
\text { paradoxically it often fails } \\
\text { to develop because of early } \\
\text { treatment.. } \\
\end{array}$ & None available & Humans & $\begin{array}{l}\text { Complex treatment } \\
\text { protocols often involving } \\
\text { penicillin }\end{array}$ \\
\hline $\begin{array}{l}\text { Tetanus, lockjaw, Obstretrical } \\
\text { tetanus, tetanus neonatorum. }\end{array}$ & $\begin{array}{l}\text { Clostridium tetani } \\
\text { Acute disease caused by } \\
\text { an exotoxin. A variety of } \\
\text { disease forms can emerge } \\
\text { after contact with the } \\
\text { causal organism. }\end{array}$ & Worldwide & $\begin{array}{l}\text { A35, A 33. A.34. } \\
\text { Relatively } \\
\text { uncommon in } \\
\text { industrialised } \\
\text { countries case } \\
\text { fatality } 2.3 \% \text { for } \\
\text { those aged under } \\
20-39 \text { and } 18 \% \text { for } \\
\text { those over } 60 \text {. Case } \\
\text { fatality can up to } \\
80 \% \text { depending on } \\
\text { quality of care. } \\
\end{array}$ & General & $\begin{array}{l}\text { Infants and elderly at higher } \\
\text { risk. Members of service } \\
\text { groups such as armed forces } \\
\text { and police and those in contact } \\
\text { with sewage. }\end{array}$ & $\begin{array}{l}\text { Paradoxically recovery } \\
\text { from infection does not } \\
\text { guarantee immunity and } \\
\text { there is no detectable } \\
\text { antibody (this is somewhat } \\
\text { of a paradox in that anti- } \\
\text { toxin immunisation is } \\
\text { effective for long periods } \\
\text { of time). }\end{array}$ & $\begin{array}{l}\text { Active long-lasting } \\
\text { immunity is elicited } \\
\text { by toxoid }\end{array}$ & \begin{tabular}{|l|} 
Intestines of cattle \\
and soil in which \\
human and or \\
animal faeces are \\
found. The organism \\
is essentially \\
everywhere.
\end{tabular} & $\begin{array}{l}\text { Prophylactic antibiotics in } \\
\text { those by culture felt to be } \\
\text { at risk }\end{array}$ \\
\hline Trachoma, & $\begin{array}{l}\text { Chlamydia trachomatis, } \\
\text { specific serovars. } \\
\text { Initially conjunctivitis, } \\
\text { Can resolve } \\
\text { spontaneously but } \\
\text { repeated reinfection can } \\
\text { lead to blindness. } \\
\end{array}$ & $\begin{array}{l}\text { Worldwide occurring } \\
\text { as an endemic disease } \\
\text { largely in poorer } \\
\text { communities }\end{array}$ & \begin{tabular}{|l|} 
A71 \\
A major cause of \\
development of \\
blindness over a long \\
period of time.
\end{tabular} & $\begin{array}{l}\text { General. Active disease } \\
\text { tends not to be seen in older } \\
\text { children andadults }\end{array}$ & $\begin{array}{l}\text { Poor living conditions, } \\
\text { Dust and fine sand may } \\
\text { exacerbate the condition. }\end{array}$ & No evidence for immunity & None successful & Humans & $\begin{array}{l}\text { A major disease but } \\
\text { seemingly curable. Topical } \\
\text { tetracylines can be effective. } \\
\text { Repositioning of eyelashes } \\
\text { so they no longer abrade the } \\
\text { cornea can be effective. }\end{array}$ \\
\hline
\end{tabular}

Infect Dis Ther, Volume 1(2): 13-48, 2020 


\begin{tabular}{|c|c|c|c|c|c|c|c|c|c|}
\hline Disease & $\begin{array}{l}\text { Infectious agent. } \\
\text { Target organ if any. }\end{array}$ & Location & $\begin{array}{l}\text { ICD } 10 \text { entry. } \\
\text { Impact }\end{array}$ & Susceptibility & Special risk factors & Immunity & Vaccines & $\begin{array}{l}\text { Primary reservoir } \\
\text { and vectors }\end{array}$ & Comments, treatment \\
\hline Trench fever, Quintana fever & $\begin{array}{l}\text { Bartonella quintana } \\
\text { A typically febrile non } \\
\text { fatalsepticaemia. }\end{array}$ & $\begin{array}{l}\text { Scattered but in many } \\
\text { places }\end{array}$ & \begin{tabular}{|l} 
A79 \\
Particularly \\
prevalent in world \\
war one trenches \\
\end{tabular} & General & $\begin{array}{l}\text { Immunocompromised patients } \\
\text { have a variety of severe } \\
\text { symptoms }\end{array}$ & unknown & None recorded & $\begin{array}{l}\text { Humans but vector } \\
\text { is the body louse. }\end{array}$ & Tetracyclines \\
\hline Tuberculosis, TB & $\begin{array}{l}\text { Mycobacterium } \\
\text { tuberculosis and to far } \\
\text { lesser extent } \text { M.bovis. } \\
\text { It is estimated that } 1 / 3 \\
\text { of the world population } \\
\text { is presently infected. } \\
\text { Active disease can be } \\
\text { pulmonary or extra } \\
\text { pulmonary. } \\
\text { There is given in the } \\
\text { manual a brief account } \\
\text { of non-tuberculous } \\
\text { mycobacterial disease. } \\
\text { Here it is not considered. }\end{array}$ & Worldwide & \begin{tabular}{|l|} 
AA15-19 \\
Probably the \\
biggest single \\
cause of mortality \\
and disability \\
associated with \\
infection. Despite \\
this it is likely \\
that the majority \\
$(90 \%)$ ofthose \\
infected enter a \\
latent condition \\
from which there is \\
always a danger of \\
reactivation. \\
\end{tabular} & $\begin{array}{l}\text { Ostensibly risk of infection } \\
\text { is related to degree of } \\
\text { exposure. The first six } \\
\text { to twelve months after } \\
\text { infection are the most } \\
\text { dangerous for development } \\
\text { of full blown disease. }\end{array}$ & $\begin{array}{l}\text { Risk of developing disease } \\
\text { highest under the age of } 3 \text {, } \\
\text { lowest in later childhood } \\
\text { and high again among young } \\
\text { adults the aged and the } \\
\text { immunosuppressed with HIV. } \\
\text { Other debilitating diseases can } \\
\text { contribute to the likelihood of } \\
\text { reactivation. }\end{array}$ & $\begin{array}{l}\text { The utility in some } \\
\text { circumstances of BCG } \\
\text { vaccination suggests } \\
\text { that there is a degree of } \\
\text { immunological control } \\
\text { but one wonders if this is } \\
\text { niche occupation rather } \\
\text { than immunity per se. } \\
\text { There is little in the text } \\
\text { about immunity except } \\
\text { in relation to the PPD } \\
\text { skin testing that is usually } \\
\text { positive in infected people. } \\
\text { This is a very complex } \\
\text { story } \\
\end{array}$ & $\begin{array}{l}\text { BCG has been } \\
\text { deployed but in some } \\
\text { circumstances it } \\
\text { seems not to work } \\
\text { in terms of avoiding } \\
\text { disease. The whole } \\
\text { issue is complicated } \\
\text { by the differences in } \\
\text { frequency of wild type } \\
\text { challenge in some of } \\
\text { the regions that are } \\
\text { being compared. }\end{array}$ & $\begin{array}{l}\text { Humans primarily. } \\
\text { The argument in } \\
\text { relation to badgers } \\
\text { and cattle still rages. }\end{array}$ & $\begin{array}{l}\text { Antimicrobials. Whether } \\
\text { latent TB should be treated } \\
\text { seems not to have been } \\
\text { addressed. Also the latent } \\
\text { status seems to be little } \\
\text { understood }\end{array}$ \\
\hline Disease & \begin{tabular}{|l|} 
Infectious agent. \\
Target organ if any.
\end{tabular} & Location & $\begin{array}{l}\text { ICD } 10 \text { entry. } \\
\text { Impact }\end{array}$ & Susceptibility & Special risk factors & Immunity & Vaccines & \begin{tabular}{|l|} 
Primary reservoir \\
and vectors
\end{tabular} & Comments, treatment \\
\hline $\begin{array}{l}\text { Tularaemia, Rabbit fever, Deer- } \\
\text { fly fever, Ohara disease, Francis } \\
\text { disease. }\end{array}$ & \begin{tabular}{|l|} 
Francisellatularensis \\
Skin and \\
lymphadenopathy, or the \\
latter without the former.
\end{tabular} & $\begin{array}{l}\text { N America, former } \\
\text { Soviet Union China } \\
\text { and Japan }\end{array}$ & \begin{tabular}{|l|} 
A21 \\
Complex set of \\
diseases with a wide \\
variety of symptoms. \\
\end{tabular} & $\begin{array}{l}\text { All ages susceptible, and } \\
\text { presumably all people }\end{array}$ & $\begin{array}{l}\text { Closely linked to occupational } \\
\text { and recreational activities. }\end{array}$ & $\begin{array}{l}\text { Long term immunity } \\
\text { follows recovery from } \\
\text { infection. }\end{array}$ & None & \begin{tabular}{|l|} 
Numerous wild \\
animals, with a tick \\
vectorusually or, less \\
commonly, deer fly \\
\end{tabular} & Streptomycin. \\
\hline $\begin{array}{l}\text { Typhoid, paratyphoid } \\
\text { fever, enteric fever, typhus } \\
\text { abdominalis. }\end{array}$ & Salmonella typhi & $\begin{array}{l}\text { Worldwide major } \\
\text { diseases of which } \\
\text { paratyphoid is the } \\
\text { milder. }\end{array}$ & $\begin{array}{l}\text { A01.0 A01.4 } \\
\text { No of cases } \\
\text { annually estimated } \\
\text { at } 17 \text { million } \\
\text { cases annually } \\
\text { with estimated } \\
600,000 ! \text { Deaths. } \\
\text { Many mild } \\
\text { and inapparent } \\
\text { infections occur } \\
\end{array}$ & General & $\begin{array}{l}\text { Achlorhydria, HIV infection, } \\
\text { IN endemic areas disease is } \\
\text { most common in children up } \\
\text { to } 19 \text { years of age. }\end{array}$ & $\begin{array}{l}\text { Relative specific immunity } \\
\text { follows infection with } \\
\text { disease, unapparent } \\
\text { infection, or active } \\
\text { immunisation }\end{array}$ & $\begin{array}{l}\text { A double vaccine is } \\
\text { available, one part live } \\
\text { and the other a coat } \\
\text { polysaccharide (from } \\
\text { paratyphus). They } \\
\text { are not uniformly } \\
\text { successful. }\end{array}$ & $\begin{array}{l}\text { Humans for typhoid, } \\
\text { andparatyphoid. } \\
\text { More rarely animals } \\
\text { for paratyphoid. } \\
\text { Some chronic } \\
\text { carriers. }\end{array}$ & $\begin{array}{l}\text { Antibiotics but resistance is } \\
\text { becoming an increasingly } \\
\text { difficult problem. }\end{array}$ \\
\hline $\begin{array}{l}\text { Typhus fever, epidemic louse } \\
\text { borne typhus fever }\end{array}$ & $\begin{array}{l}\text { Rickettsia prowazekii } \\
\text { A wide variety of } \\
\text { systemic symptoms } \\
\text { with a specifically } \\
\text { recognized(Brill-Zinser) } \\
\text { disease occurring year } \\
\text { after the primary attack. }\end{array}$ & $\begin{array}{l}\text { In colder areas where } \\
\text { people may live in } \\
\text { unsanitary conditions } \\
\text { and are infested with } \\
\text { lice. }\end{array}$ & \begin{tabular}{|l|} 
A75, case fatality \\
untreated varies \\
from $10-40 \%$.Mild \\
infections can occur \\
without eruptions \\
especially in children \\
and those partially \\
immunized
\end{tabular} & General & None stated & $\begin{array}{l}\text { One attack gives lifelong } \\
\text { immunity This is stated } \\
\text { in earlier editions of the } \\
\text { manual but not repeated } \\
\text { in the } 20^{\text {th }} \text { edition. }\end{array}$ & None & $\begin{array}{l}\text { Humans and to a } \\
\text { limited extent flying } \\
\text { squirrels. The vector } \\
\text { is the body louse. }\end{array}$ & $\begin{array}{l}\text { Antibiotic treatment, } \\
\text { doxycycline, usually } \\
\text { effective. }\end{array}$ \\
\hline
\end{tabular}




\begin{tabular}{|c|c|c|c|c|c|c|c|c|c|}
\hline Disease & \begin{tabular}{|l} 
Infectious agent. \\
Target organ if any.
\end{tabular} & Location & $\begin{array}{l}\text { ICD } 10 \text { entry. } \\
\text { Impact }\end{array}$ & Susceptibility & Special risk factors & Immunity & Vaccines & $\begin{array}{l}\text { Primary reservoir } \\
\text { and vectors }\end{array}$ & Comments, treatment \\
\hline $\begin{array}{l}\text { Typhus fever, epidemic flea } \\
\text { borne typhus, murine typhus, } \\
\text { shop typhus. }\end{array}$ & $\begin{array}{l}\text { Rickettsia typhi } \\
\text { Manifestations of disease } \\
\text { like those associated with } \\
\text { louse borne disease. }\end{array}$ & Worldwide & \begin{tabular}{|l|} 
A75.22 \\
Milder than \\
the louse borne \\
equivalent \\
\end{tabular} & General & None given & $\begin{array}{l}\text { One attack confers } \\
\text { immunity. }\end{array}$ & None & \begin{tabular}{|l|} 
Rats mice and \\
probably other small \\
mammals, vector \\
infected rat fleas. \\
\end{tabular} & Tetracyclines \\
\hline $\begin{array}{l}\text { Scrub typhus, tsutsugamushi } \\
\text { disease. Miteborne typhus } \\
\text { fever }\end{array}$ & $\begin{array}{l}\text { Orientia tsutsugamushi } \\
\text { with many serotypes. } \\
\text { and a wide variety of } \\
\text { symptoms often dermal } \\
\text { initially. }\end{array}$ & $\begin{array}{l}\text { Central and South } \\
\text { East Asia }\end{array}$ & $\begin{array}{l}\text { A75.3 } \\
\text { Case fatality rate } \\
\text { untreated as high } \\
\text { as } 60 \%\end{array}$ & General & $\begin{array}{l}\text { Bigger problems with } \\
\text { older people, occupational } \\
\text { particularly militarytroops }\end{array}$ & $\begin{array}{l}\text { Prolonged immunity } \\
\text { against the homologous } \\
\text { strain. Unpredictable for } \\
\text { heterologous challenge }\end{array}$ & None successful & $\begin{array}{l}\text { Thrombiculid mites } \\
\text { are the reservoir }\end{array}$ & Tetracyclines \\
\hline Yaws, Frambesiatropica. & $\begin{array}{l}\text { Treponema pallidum } \\
\text { Highly unpleasant skin } \\
\text { disorders. }\end{array}$ & $\begin{array}{l}\text { A disease of children } \\
\text { in moist tropical } \\
\text { regions }\end{array}$ & \begin{tabular}{|l|} 
A66Rarely fatal \\
but can be very \\
disfiguring and \\
maiming. \\
\end{tabular} & $\begin{array}{l}\text { No evidence of natural or } \\
\text { racial resistance }\end{array}$ & $\begin{array}{l}\text { More frequent in male } \\
\text { children }\end{array}$ & \begin{tabular}{|l|} 
Infection results in \\
immunity and sometimes \\
resistance to other \\
pathogenic treponemes
\end{tabular} & None & Humans & Pencillin \\
\hline Yersiniosis, & $\begin{array}{l}\text { Yersinia enterocolitica, Y. } \\
\text { pseudotuberculosis } \\
\text { Typically manifest as } \\
\text { acute febrile diarrhoea } \\
\text { with abdominal pain. }\end{array}$ & World wide & \begin{tabular}{|l} 
A04.6Complex \\
pattern of \\
susceptibility, post \\
infection arthritis \\
is more severe in \\
adolescents and \\
young adults \\
\end{tabular} & $\begin{array}{l}\text { No statement but inference } \\
\text { is that susceptibility is } \\
\text { universal }\end{array}$ & \begin{tabular}{|l|} 
HLa-B27 positive patients \\
more susceptible to reactive \\
arthritis and Reiter's syndrome. \\
Septicaemia occurs more \\
often in those with an iron \\
overload or with underlying \\
immunosuppression.
\end{tabular} & Nothing stated & None & \begin{tabular}{|l|} 
Animals particularly \\
the pig, i.e., a \\
zoonosis
\end{tabular} & $\begin{array}{l}\text { Organisms are sensitive to } \\
\text { many antibiotics but not to } \\
\text { penicillin. }\end{array}$ \\
\hline
\end{tabular}

\begin{tabular}{|c|c|c|c|c|c|c|c|c|c|}
\hline Disease & $\begin{array}{l}\text { Infectious agent. } \\
\text { Target organ if any. }\end{array}$ & Location & $\begin{array}{l}\text { ICD } 10 \text { entry. } \\
\text { Impact }\end{array}$ & Susceptibility & Special risk factors & Immunity & Vaccines & \begin{tabular}{|l|} 
Primary \\
reservoir and \\
vectors
\end{tabular} & Comments and Treatment \\
\hline $\begin{array}{l}\text { Arenoviral, Haemorrhagic fevers, } \\
\text { Junin, Matupo, Guanarito, Sabia, } \\
\text { chapare.(this last not ICD listed). } \\
\text { New world. }\end{array}$ & $\begin{array}{l}\text { Tachibe tribe of arenoviruses } \\
\text { Acute febrile illnesses typically } \\
\text { lasting for up to } 14 \text { days }\end{array}$ & $\begin{array}{l}\text { South America } \\
\text { particularly } \\
\text { Bolivia, Argentina, } \\
\text { Venezuela and } \\
\text { Brazil }\end{array}$ & $\begin{array}{l}\text { A96.0,A96.1, A96.2,A96.8, } \\
\text { Occasional epidemics with } \\
\text { lethality up to } 30 \% \text { Variable } \\
\text { according to location and } \\
\text { causal agent }\end{array}$ & All ages susceptible & $\begin{array}{l}\text { Largely occupational with } \\
\text { reference to laboratory } \\
\text { workers. }\end{array}$ & $\begin{array}{l}\text { Protective immunity } \\
\text { of unknown duration } \\
\text { follows infection. }\end{array}$ & $\begin{array}{l}\text { A live virus for } \\
\text { the Argentinian } \\
\text { disease }\end{array}$ & $\begin{array}{l}\text { Various wild } \\
\text { rodents }\end{array}$ & $\begin{array}{l}\text { Sub-clinical infections occur. } \\
\text { Immune plasma only remedybut } \\
\text { it is effective in some instances in } \\
\text { the Argentine form of the diseases. } \\
\text { Ribavirin also useful across the } \\
\text { board. }\end{array}$ \\
\hline
\end{tabular}

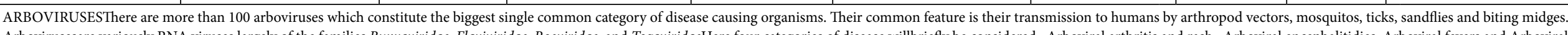

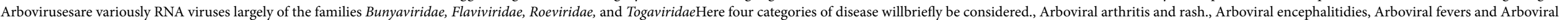

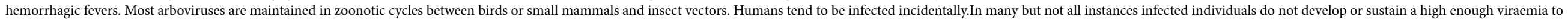

\begin{tabular}{|c|c|c|c|c|c|c|c|c|c|}
\hline Disease & $\begin{array}{l}\text { Infectious agent. } \\
\text { Target organ if any. }\end{array}$ & Location & $\begin{array}{l}\text { ICD } 10 \text { entry. } \\
\text { Impact }\end{array}$ & Susceptibility & Special risk factors & Immunity & Vaccines & $\begin{array}{l}\text { Primary } \\
\text { reservoir and } \\
\text { vectors }\end{array}$ & Comments, treatment \\
\hline $\begin{array}{l}\text { Arbo-virus encephalitides; } \\
\text { Mosquito borne - at least } 25 \\
\text { separate diseases with similar } \\
\text { features but occurring in different } \\
\text { localities and associated with } \\
\text { different local strains of virus. } \\
\text { Japanese encephalitis virus } \\
\text { and West Nile virus are listed } \\
\text { separately. }\end{array}$ & $\begin{array}{l}\text { Local viruses, alpha viruses, } \\
\text { flaviviruses, and Bunya viruses } \\
\text { Most infections are } \\
\text { asymptomatic or result in } \\
\text { undifferentiated febrile } \\
\text { illness. Many forms of later } \\
\text { complication. }\end{array}$ & $\begin{array}{l}\text { Almost anywhere } \\
\text { that has } \\
\text { mosquitoes. }\end{array}$ & $\begin{array}{l}\text { A83.8,A83.2, A83.5,A83.4, } \\
\text { A83.6, A84.1, A92.2, A83.1. } \\
\text { Hugely variable some rarely } \\
\text { lethal others with significant } \\
\text { mortality. }\end{array}$ & $\begin{array}{l}\text { Many adults have } \\
\text { acquired immunity } \\
\text { Children, visitors } \\
\text { and those new to the } \\
\text { area tend to be most } \\
\text { diseased. }\end{array}$ & $\begin{array}{l}\text { The young and the old are } \\
\text { more susceptible. Various } \\
\text { medical conditions predispose } \\
\text { to severity of disease. }\end{array}$ & \begin{tabular}{|l} 
Infection usually \\
results inlifelong \\
homologous immunity
\end{tabular} & $\begin{array}{l}\text { A variety of } \\
\text { live and dead } \\
\text { vaccines are used } \\
\text { for a few of the } \\
\text { diseases in this } \\
\text { group. }\end{array}$ & $\begin{array}{l}\text { Birds, small } \\
\text { mammals }\end{array}$ & $\begin{array}{l}\text { Inapparent infections usual in } \\
\text { younger adults. No treatment } \\
\text { available. }\end{array}$ \\
\hline
\end{tabular}

Infect Dis Ther, Volume 1(2): 15-48, 2020 


\begin{tabular}{|c|c|c|c|c|c|c|c|c|c|}
\hline Disease & $\begin{array}{l}\text { Infectious agent. } \\
\text { Target organ if any. }\end{array}$ & Location & $\begin{array}{l}\text { ICD } 10 \text { entry. } \\
\text { Impact }\end{array}$ & Susceptibility & Special risk factors & Immunity & Vaccines & \begin{tabular}{|l|l}
$\begin{array}{l}\text { Primary } \\
\text { reservoir and } \\
\text { vectors }\end{array}$ & C \\
\end{tabular} & Comments, treatment \\
\hline $\begin{array}{l}\text { Arboviral fevers, vectors, } \\
\text { Mosquitos, sand flies and biting } \\
\text { midges. } 25 \text { listed in the } 20^{\text {th }} \\
\text { edition. Rift Valley fever listed } \\
\text { separately. }\end{array}$ & \begin{tabular}{|l|} 
Single stranded RNA viruses \\
of various families primarily \\
Flaviviridae, and Bunyaviridae \\
or double stranded RNA \\
viruses of the family Reoviridae \\
Febrile illnesses lasting a week \\
or so rarely fatal
\end{tabular} & $\begin{array}{l}\text { Global but tropical } \\
\text { or sub-tropical in } \\
\text { the main. }\end{array}$ & $\begin{array}{l}\text { A92.8, A93.8, A 93.2, A93.0, } \\
\text { A93.1, B33.8, } \\
\text { less than ten per cent were } \\
\text { serious in an American } \\
\text { outbreak }\end{array}$ & $\begin{array}{l}\text { General, mild } \\
\text { infections and } \\
\text { subsequent immunity } \\
\text { occur frequently in } \\
\text { endemic areas }\end{array}$ & $\begin{array}{l}\text { Children at higher } \\
\text { risk of CNS infection. } \\
\text { Immunocompromised } \\
\text { individuals at higher risk of } \\
\text { symptomatic infection. }\end{array}$ & $\begin{array}{l}\text { Lifelong immunity } \\
\text { after infection is usual }\end{array}$ & $\begin{array}{l}\text { No vaccines } \\
\text { mentioned. }\end{array}$ & $\begin{array}{l}\text { Complex } \\
\text { patterns of } \\
\text { transmission. }\end{array} \mid \mathrm{N}$ & No specific treatments \\
\hline $\begin{array}{l}\text { Arboviral haemorrhagic fevers. } 4 \\
\text { listed, Yellow fever and Dengue } \\
\text { are listed separately. }\end{array}$ & $\begin{array}{l}\text { Causal agents Flaviviridae and } \\
\text { Bunyaviridae. }\end{array}$ & $\begin{array}{l}\text { Specific regions } \\
\text { for the different } \\
\text { diseases. Often } \\
\text { seasonal relating to } \\
\text { vector prevalence. }\end{array}$ & $\begin{array}{l}\text { A98.0, A98.1, A98.2. serious } \\
\text { diseases with distressing } \\
\text { symptoms and very variable } \\
\text { mortalities ranging from } \\
1-30-\%\end{array}$ & $\begin{array}{l}\text { Often health care } \\
\text { workers, abattoir } \\
\text { workers owners of } \\
\text { livestock. }\end{array}$ & Occupational risks. & $\begin{array}{l}\text { Lifelong immunity } \\
\text { after infection is usual }\end{array}$ & \begin{tabular}{|l} 
Some vaccines \\
have been \\
developed but \\
overall use \\
controversial at \\
present.
\end{tabular} & \begin{tabular}{|l|l|} 
Wide range & \\
of reservoirs \\
which vary \\
according to \\
the specific \\
diseases.
\end{tabular} & No specific treatments \\
\hline \multicolumn{10}{|c|}{ 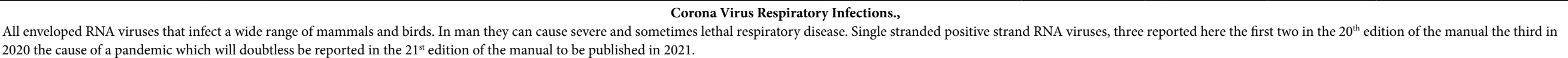 } \\
\hline $\begin{array}{l}\text { Corona virus respiratory } \\
\text { infections MERS, Middle East } \\
\text { respiratory syndrome }\end{array}$ & $\begin{array}{l}\text { MERS -CoV } \\
\text { As above }\end{array}$ & $\begin{array}{l}\text { All cases known } \\
\text { are linked to the } \\
\text { Middle East. }\end{array}$ & \begin{tabular}{|l} 
None presently allocated. \\
By mid-2014 699 laboratory \\
confirmed cases were \\
reported to WHO with at \\
least 209 deaths. Sporadic \\
human cases are considered \\
likely to continue. \\
\end{tabular} & $\begin{array}{l}\text { Not known except } \\
\text { for common co- } \\
\text { morbidities and } \\
\text { contact with infected } \\
\text { individuals. }\end{array}$ & $\begin{array}{l}\text { A variety of co-morbidities } \\
\text { such as diabetes } \\
\text { immunosuppression and } \\
\text { heart disease most commonly } \\
\text { reported. }\end{array}$ & $\begin{array}{l}\mathrm{u} \\
\mathrm{p} \\
\mathrm{c}\end{array}$ & $\begin{array}{l}\text { Use of convalescent } \\
\text { plasma has been } \\
\text { considered. }\end{array}$ & \begin{tabular}{|l} 
Direct contact \\
and fomites \\
recognisedwith \\
camels found to \\
have high titres \\
of neutralising \\
antibodies. \\
\end{tabular} & $\begin{array}{l}\text { No anti-virals have been } \\
\text { deployed but with some patients } \\
\text { prophylactic antibiotics have } \\
\text { been used. }\end{array}$ \\
\hline SARS & $\begin{array}{l}\text { Sars corona virus single } \\
\text { stranded RNA. Upper } \\
\text { respiratory tract }\end{array}$ & \begin{tabular}{|l|} 
No certainty where \\
it originated but \\
it certainly spread \\
internationally.
\end{tabular} & $\begin{array}{l}\text { U04. } 9 \text { provisional } \\
\text { Up ro } 10 \% \text { mortality in those } \\
\text { infected. }\end{array}$ & $\begin{array}{l}\text { Difficult to say } \\
\text { as presentation } \\
\text { is variable but no } \\
\text { information given } \\
\text { on asymptomaatic } \\
\text { infections. }\end{array}$ & \begin{tabular}{|l|} 
Originally thought to have \\
been a zoonosis. Those in \\
contact with working with the \\
vectors Are at higher risk. I \\
Without diagrnosis nosocomial \\
infections were common and \\
without doubt most of later \\
infections were consequent \\
upon contagion from infected \\
patients.
\end{tabular} & None indicated. & $\begin{array}{l}\text { Himalayan masked } \\
\text { civet and horshoe } \\
\text { bats but main } \\
\text { problems derives } \\
\text { from infected } \\
\text { humans }\end{array}$ & \begin{tabular}{|l|} 
Most measures \\
taken to diminish \\
the dissease \\
involve good \\
health care \\
practice and \\
wearing of \\
mask to restrict \\
transmission by \\
droplets..
\end{tabular} & \\
\hline
\end{tabular}




\begin{tabular}{|c|c|c|c|c|c|c|c|c|c|}
\hline Disease & $\begin{array}{l}\text { Infectious agent. } \\
\text { Target organ if any. }\end{array}$ & Location & $\begin{array}{l}\text { ICD } 10 \text { entry. } \\
\text { Impact }\end{array}$ & Susceptibility & Special risk factors & Immunity & Vaccines & \begin{tabular}{|l|} 
Primary \\
reservoir and \\
vectors
\end{tabular} & Comments, treatment \\
\hline $\begin{array}{l}\text { Corona virus respiratory } \\
\text { infections Covid-19 }\end{array}$ & $\begin{array}{l}\text { SARS-CoV-2 } \\
\text { Huge impact worldwide with } \\
\text { many millions of cases and a } \\
\text { significant mortality. }\end{array}$ & $\begin{array}{l}\text { Worldwide though } \\
\text { major differences } \\
\text { have been found } \\
\text { between incidences } \\
\text { in countries. }\end{array}$ & $\begin{array}{l}\text { Emergency code of U07 } \\
\text { allocated. } \\
\text { Massive impact on health } \\
\text { services and great economic } \\
\text { impact as a consequence } \\
\text { of the steps enforced by } \\
\text { national governments in } \\
\text { their attempts to prevent the } \\
\text { spread of infection. }\end{array}$ & $\begin{array}{l}\text { Older ages at special } \\
\text { risk but cases known } \\
\text { in all ages. }\end{array}$ & $\begin{array}{l}\text { Age and prior health } \\
\text { conditions. A significant } \\
\text { proportion of those } \\
\text { hospitalised and dying had } \\
\text { prior bad health. }\end{array}$ & $\begin{array}{l}\text { Antibodies are } \\
\text { produced in } \\
\text { severe cases but it } \\
\text { is recorded (27) } \\
\text { that asymptomatic } \\
\text { cases do not show } \\
\text { antibody. }\end{array}$ & $\begin{array}{l}\text { Many presently } \\
\text { in preparation as } \\
\text { the authorities are } \\
\text { wedded to the idea } \\
\text { that vaccines are } \\
\text { the answer. }\end{array}$ & $\begin{array}{l}\text { The causal agent } \\
\text { is said to be new. } \\
\text { Arguments rage } \\
\text { about where } \\
\text { the first cases } \\
\text { appeared. In } \\
\text { late } 2020 \text { we } \\
\text { are desperately } \\
\text { short of hard } \\
\text { information } \\
\text { about the biology } \\
\text { of the disease } \\
\text { and why some } \\
70 \% \text { of those } \\
\text { infected remain } \\
\text { asymptomtic. }\end{array}$ & $\begin{array}{l}\text { Declared pandemic by WHO } \\
\text { with subsequent enormous } \\
\text { attempts to stop it. }\end{array}$ \\
\hline $\begin{array}{l}\text { Keratoconjunctivitis, adenoviral, } \\
\text { shipyard eye.Bacterial } \\
\text { conjunctivitis dealt with in } \\
\text { bacterial tables. }\end{array}$ & $\begin{array}{l}\text { Adenoviruses types 8, } 19 \text { and } \\
37 \text { in the USA } \\
\text { Eyes. }\end{array}$ & $\begin{array}{l}\text { Presumably } \\
\text { worldwide. } \\
\text { Outbreaks have } \\
\text { occurred in Asia, } \\
\text { Hawaii, North } \\
\text { America and } \\
\text { Europe } \\
\end{array}$ & $\begin{array}{l}\text { B30.0 } \\
\text { Unusually residual scarring } \\
\text { appears }\end{array}$ & $\begin{array}{l}\text { Not stated presumably } \\
\text { universal }\end{array}$ & $\begin{array}{l}\text { Any trauma can increase the } \\
\text { risk of infection }\end{array}$ & $\begin{array}{l}\text { Usually long- } \\
\text { lasting type specific } \\
\text { immunity after } \\
\text { infection. }\end{array}$ & N/A & Humans & $\begin{array}{l}\text { Often associated with } \\
\text { eye clinics! Clearly a very } \\
\text { contagious agent. No treatment } \\
\text { during acute phase. }\end{array}$ \\
\hline $\begin{array}{l}\text { Adenoviral haemorrhagic } \\
\text { conjunctivitis, } \\
\text { Pharyngoconjunctival fever }\end{array}$ & $\begin{array}{l}\text { Adenoviruses and } \\
\text { picornaviruses }\end{array}$ & $\begin{array}{l}\text { Summer epidemics } \\
\text { associated with } \\
\text { swimming pools }\end{array}$ & $\begin{array}{l}\text { B30.0 } \\
\text { Usually mild but severe } \\
\text { chronic cases with residual } \\
\text { neurological complications } \\
\text { are recorded. }\end{array}$ & $\begin{array}{l}\text { All ages can be } \\
\text { affected. Associated } \\
\text { with institutional } \\
\text { overcrowding. }\end{array}$ & ? & $\begin{array}{l}\text { Reinfections } \\
\text { and relapses are } \\
\text { reported the role } \\
\text { and duration of } \\
\text { immunity if anyis } \\
\text { not clear }\end{array}$ & N/A & Humans & $\begin{array}{l}\text { Swimming pool disease. no } \\
\text { specific treatment }\end{array}$ \\
\hline Disease & $\begin{array}{l}\text { Infectious agent. } \\
\text { Target organ if any. }\end{array}$ & Location & $\begin{array}{l}\text { ICD 10entry. } \\
\text { Impact }\end{array}$ & Susceptibility & Special risk factors & Immunity & Vaccines & \begin{tabular}{|l} 
Primary \\
reservoir and \\
vectors
\end{tabular} & Comments, treatment \\
\hline \begin{tabular}{|l|} 
Coxsackievirus diseases, vesicular \\
pharyngitis, vesicular stomatitis \\
with exanthema (hand foot and \\
mouth disease), lymphonodular \\
pharyngitis. Not recorded in \\
$20^{\text {th }}$ edition. \\
\end{tabular} & Various coxsackieviruses & $\begin{array}{l}\text { Worldwide sporadic } \\
\text { particularly the } \\
\text { lymphonodular } \\
\text { pharyngitis }\end{array}$ & $\begin{array}{l}\text { ICD 9, 074, ICD 10, B34. } \\
\text { In general self limiting }\end{array}$ & Universal & Not stated & \begin{tabular}{|l|} 
Type specific \\
Immunity acquired \\
by clinical or \\
inapparent \\
infection, duration \\
unknown \\
\end{tabular} & $\mathrm{N} / \mathrm{A}$ & Humans & $\begin{array}{l}\text { associated with juvenile diabetes } \\
\text { No specific treatment }\end{array}$ \\
\hline $\begin{array}{l}\text { Cytomegalovirus infections adult } \\
\text { and congenital, }\end{array}$ & $\begin{array}{l}\text { Human (beta) herpes virus } 5 \\
\text { inter alia. } \\
\text { Febrile illness }\end{array}$ & Ubiquitous & $\begin{array}{l}\text { B25, P35.1 } \\
\text { Very drastic on affected } \\
\text { infants and many of those } \\
\text { who are immunosuppressed }\end{array}$ & Ubiquitous & $\begin{array}{l}\text { Immaturity and } \\
\text { immunopareses of many kinds. } \\
\text { It causes enormous problems in } \\
\text { transplant patients. }\end{array}$ & \begin{tabular}{|l|} 
It produces \\
symptoms relatively \\
rarely. it is the classic \\
example of the \\
persistent inapparent \\
infection. As many \\
as $100 \%$ of people in \\
developing countries \\
have antibodies \\
and all have the \\
infection!
\end{tabular} & $\begin{array}{l}\text { None generally } \\
\text { available }\end{array}$ & $\begin{array}{l}\text { Man. The animal } \\
\text { CMVs do not } \\
\text { infect humans }\end{array}$ & $\begin{array}{l}\text { Transmission of the disease } \\
\text { is by intimate contact with } \\
\text { infected mucosal surfaces. CTX } \\
\text { ganciclovir }\end{array}$ \\
\hline
\end{tabular}

Infect Dis Ther, Volume 1(2): 17-48, 2020 


\begin{tabular}{|c|c|c|c|c|c|c|c|c|c|}
\hline Dengue fever, break bone fever & $\begin{array}{l}\text { Flaviviruses of specific } \\
\text { serotypes } \\
\text { Acute febrile illness }\end{array}$ & $\begin{array}{l}\text { Endemic in most } \\
\text { tropical countries }\end{array}$ & $\begin{array}{l}\text { A } 90 . \\
\text { Rarely fatal except in } \\
\text { instances of haemorrhagic } \\
\text { complications }\end{array}$ & universal & $\begin{array}{l}\text { Children affected less than } \\
\text { adults }\end{array}$ & \begin{tabular}{|l} 
Serotype specific \\
and effective \\
immunity develops \\
that is lifelong.
\end{tabular} & None & $\begin{array}{l}\text { Human with } \\
\text { mosquito vectors }\end{array}$ & $\begin{array}{l}\text { Although rarely lethal it can } \\
\text { cause large scale epidemics } \\
\text { when the virus and the vector } \\
\text { coincide. Supportive treatment } \\
\text { aspirin }\end{array}$ \\
\hline Disease & $\begin{array}{l}\text { Infectious agent. } \\
\text { Target organ if any. }\end{array}$ & Location & $\begin{array}{l}\text { ICD } 10 \text { entry. } \\
\text { Impact }\end{array}$ & Susceptibility & Special risk factors & Immunity & Vaccines & \begin{tabular}{|l} 
Primary \\
reservoir and \\
vectors
\end{tabular} & Comments, treatment \\
\hline Dengue haemorrhagic fever & As above & $\begin{array}{l}\text { Outbreaks recorded } \\
\text { from many tropical } \\
\text { locations }\end{array}$ & $\begin{array}{l}\text { A91. } \\
\text { Case fatality rates of up to } \\
50 \% \text { are reported in which } \\
\text { fluid replacement has not } \\
\text { been effected. }\end{array}$ & $\begin{array}{l}\text { Universal in that } \\
\text { susceptibility tocausal } \\
\text { viruses is universal }\end{array}$ & $\begin{array}{l}\text { Antibodies to heterologous } \\
\text { infection acquired either } \\
\text { passively or as a result of a } \\
\text { previous attack are the major } \\
\text { risk factor.(see comments) }\end{array}$ & \begin{tabular}{|l} 
In this instance \\
stimulation of the \\
immune apparatus \\
has a detrimental \\
effect
\end{tabular} & None & As above & $\begin{array}{l}\text { Heterologous antibody } \\
\text { apparently enhances uptake } \\
\text { of newly entered virus into } \\
\text { mononuclear cells. The } \\
\text { consequences seem to be over } \\
\text { secretion of cytokines. }\end{array}$ \\
\hline $\begin{array}{l}\text { Ebola-Marburg virus diseases, } \\
\text { African haemorrhagic fever, }\end{array}$ & $\begin{array}{l}\text { Negative stranded Filoviridae. } \\
\text { Five Ebola viruses have so } \\
\text { far been discovered of which } \\
\text { four cause human disease. } \\
\text { The fifth can cause fatal } \\
\text { haemorrhagic disease in non- } \\
\text { human primates. Marburg } \\
\text { virus at the moment has only } \\
\text { one discovered species High } \\
\text { fever is a starting symptom } \\
\text { with a variety of detrimental } \\
\text { systemicconditions following }\end{array}$ & \begin{tabular}{l|} 
Initially recognized \\
as a zoonosis from \\
monkeys in Europe. \\
Subsequently has \\
been recognized in \\
Africa in a number \\
of epidemics with \\
high fatality
\end{tabular} & $\begin{array}{l}\text { A98.4,A98.3 } \\
\text { Extremely nasty. With } \\
\text { outbreaks in many centres } \\
\text { recorded from } 1976 \text { for } \\
\text { Ebola and from } 1967 \text { for } \\
\text { Marburg., }\end{array}$ & All ages susceptible & $\begin{array}{l}\text { Main groups at risk are patients } \\
\text { infected with contaminated } \\
\text { needles and care givers } \\
\text { in affected communities, } \\
\text { laboratory workers processing } \\
\text { infected specimens. People } \\
\text { working with wild life in non- } \\
\text { human primates in Central } \\
\text { Africa and bats }\end{array}$ & $\begin{array}{l}\text { Antibodies have } \\
\text { been found but it is } \\
\text { not yet clear what } \\
\text { their relationship } \\
\text { is to infection by } \\
\text { any of the relevant } \\
\text { viruses. Watch this } \\
\text { space. }\end{array}$ & None so far & \begin{tabular}{|l|} 
Cynomolgus \\
monkeys, bats, \\
and infected \\
patients. The \\
viruses are highly \\
contagious.
\end{tabular} & $\begin{array}{l}\text { These viruses are highly } \\
\text { pathogenic. Seem often apart } \\
\text { from monkey bites and contact } \\
\text { with direct or indirect contact } \\
\text { with infected patients tobe } \\
\text { spread by sexual intercourse. } \\
\text { Clearly in relation to Ebola } \\
\text { and Marburg disease these are } \\
\text { early days and we are short of } \\
\text { information. }\end{array}$ \\
\hline $\begin{array}{l}\text { Erythema infectiosum (fifth } \\
\text { disease) }\end{array}$ & $\begin{array}{l}\text { Human parvovirus B19 } \\
\text { A mild childhood } \\
\text { exanthematous disease } \\
\text { associated with low grade fever. }\end{array}$ & worldwide & $\begin{array}{l}\text { B } 08.3 \\
\text { Generally benign }\end{array}$ & $\begin{array}{l}\text { Universal in those } \\
\text { with blood group P } \\
\text { antigen. }\end{array}$ & $\begin{array}{l}50-80 \% \text { of adults in the USA } \\
\text { have antibodies indicating } \\
\text { contact with the organism. } \\
\text { Patients with underlying } \\
\text { anaemia particularly if they } \\
\text { get pregnant are at higher risk, } \\
\text { as are immunosuppressed } \\
\text { individuals }\end{array}$ & \begin{tabular}{|l} 
Anti-B19 \\
virusantibodies \\
seem to confer \\
resistance to disease
\end{tabular} & $\begin{array}{l}\text { One said to be } \\
\text { under development }\end{array}$ & Humans & $\begin{array}{l}\text { Intravenous Ig has been used } \\
\text { successful. }\end{array}$ \\
\hline $\begin{array}{l}\text { Exantheumsubitum, sixth disease, } \\
\text { roseola infantum }\end{array}$ & $\begin{array}{l}\text { Human herpes virus } \\
\text { HHV6Usually mildlike } \\
\text { glandular fever }\end{array}$ & Worldwide & $\begin{array}{l}\text { B08.2Slight except in } \\
\text { immunosuppressed } \\
\text { individuals }\end{array}$ & General & $\begin{array}{l}\text { Restricted almost to children under the age of five but } \\
\text { over six monhs }\end{array}$ & \begin{tabular}{|l}
$\mid \begin{array}{l}\text { Latent infection with immunity to } \\
\text { furrther infection }\end{array}$ \\
\end{tabular} & $\begin{array}{l}\text { Not developed but } \\
\text { thought about }\end{array}$ & $\begin{array}{l}\text { Humans with } \\
\text { latent infection. }\end{array}$ & $\begin{array}{l}\text { Symptomatic care but nothing } \\
\text { given as specific treatment. }\end{array}$ \\
\hline Disease & \begin{tabular}{|l} 
Infectious agent. \\
Target organ if any.
\end{tabular} & Location & $\begin{array}{l}\text { ICD } 10 \text { entry. } \\
\text { Impact }\end{array}$ & Susceptibility & Special risk factors & Immunity & Vaccines & \begin{tabular}{|l|} 
Primary \\
reservoir and \\
vectors
\end{tabular} & Comments, treatment \\
\hline $\begin{array}{l}\text { Gastroenteritis acute,viral, } \\
\text { rotaviral enteritis }\end{array}$ & $\begin{array}{l}\text { Reoviridae, many types } \\
\text { involved } \\
\text { Vomiting, fever and watery } \\
\text { diarrhoea }\end{array}$ & World wide & \begin{tabular}{|l} 
A08.0 \\
Huge, one third of all \\
hospitalised cases of \\
diarrhoeal illness in infants \\
and young children due to \\
rotavirus. It is said to be \\
responsible for up to 900,000 \\
deaths of children per year!
\end{tabular} & $\begin{array}{l}\text { Greatest between } \\
6 \text { and } 24 \text { months } \\
\text { of age beyond that } \\
\text { most have acquired } \\
\text { antibody. }\end{array}$ & $\begin{array}{l}\text { Immunocompromised } \\
\text { individuals at special risk for } \\
\text { prolonged rotavirus secretion } \\
\text { and intermittent rotaviral } \\
\text { diarrhoea }\end{array}$ & \begin{tabular}{|l|} 
Neonatal rotavirus \\
infections are \\
usual in certain \\
settings, but most \\
are asymptomatic. \\
Immunity in \\
most instances \\
is complete and \\
seems to follow \\
(asymptomatic?) \\
infection.
\end{tabular} & $\begin{array}{l}\text { One being tested } \\
\text { presently. Much } \\
\text { work has gone into } \\
\text { attempt passive } \\
\text { immunisation with } \\
\text { food containing } \\
\text { neutralising } \\
\text { antibodies. Result } \\
\text { NK. }\end{array}$ & Humans & $\begin{array}{l}\text { One of the major diseases of the } \\
\text { world. The virus can survive for } \\
\text { long periods on dry surfaces } \\
\text { and is resistant to some standard } \\
\text { disinfectants. A major cause of } \\
\text { nosocomial infection in infants. } \\
\text { Symptomatic treatment only - } \\
\text { rehydration for example. }\end{array}$ \\
\hline
\end{tabular}




\begin{tabular}{|c|c|c|c|c|c|c|c|c|c|}
\hline Norovirus infection & $\begin{array}{l}\text { Norwalk like viruses (small } \\
\text { RNA). Commonly known as } \\
\text { Norovirus. }\end{array}$ & $\begin{array}{l}\text { Worldwide and } \\
\text { common (in parts } \\
\text { of the USA } 60 \% \text { of } \\
\text { the population had } \\
\text { antibodies) }\end{array}$ & $\begin{array}{l}\text { A08.1 } \\
\text { Usually a self- limiting mild } \\
\text { to moderate disease }\end{array}$ & widespread & $\begin{array}{l}\text { Adults }>65 \text { and children } \\
<5 \text { year at special risk of } \\
\text { developing a severe disease. }\end{array}$ & \begin{tabular}{|l|} 
Antibody levels \\
did not correlate \\
with resistance or \\
susceptibility. Short \\
lived immunity up \\
to 14 weeks was \\
shown in volunteers \\
butnot always \\
thereafter \\
\end{tabular} & none & Humans & $\begin{array}{l}\text { Associated particularly with the } \\
\text { consumption of raw shellfish. } \\
\text { Fluid replacement only. Can be } \\
\text { anosocomial infection }\end{array}$ \\
\hline $\begin{array}{l}\text { Hanta virus disease, } \\
\text { haemorrhagic fever with renal } \\
\text { syndrome }\end{array}$ & $\begin{array}{l}\text { Hantaviruses of various strains. } \\
\text { This and the, pulmonary } \\
\text { syndrome are both acute } \\
\text { zoonotic diseases with a febrile } \\
\text { prodrome, thrombocytopenia. } \\
\text { leukocytosis and capillary } \\
\text { leakage. } \\
\end{array}$ & widespread. & \begin{tabular}{|l} 
A98.5 \\
In its worst manifestation up \\
to $15 \%$ mortality
\end{tabular} & $\begin{array}{l}\text { Uniform susceptibility } \\
\text { except perhaps those } \\
\text { who have evidence of } \\
\text { previous infection! }\end{array}$ & $\begin{array}{l}\text { Occupational risks for hospital } \\
\text { personnel and animal handlers }\end{array}$ & $\left|\begin{array}{l}\text { Yes, second attacks } \\
\text { not documented }\end{array}\right|$ & None & $\begin{array}{l}\text { Field rodents, } \\
\text { humans are an } \\
\text { accidental host }\end{array}$ & $\begin{array}{l}\text { Obvious zoonosis, fluid } \\
\text { management }\end{array}$ \\
\hline Disease & $\begin{array}{l}\text { Infectious agent. } \\
\text { Target organ if any. }\end{array}$ & Location & $\begin{array}{l}\text { ICD } 10 \text { entry. } \\
\text { Impact }\end{array}$ & Susceptibility & Special risk factors & Immunity & Vaccines & \begin{tabular}{|l|} 
Primary \\
reservoir and \\
vectors
\end{tabular} & Comments, treatment \\
\hline $\begin{array}{l}\text { Hanta virus disease, pulmonary } \\
\text { syndrome }\end{array}$ & As above & $\begin{array}{l}\text { Restricted depends } \\
\text { on distribution of } \\
\text { carrier rodents }\end{array}$ & \begin{tabular}{|l} 
B33.4 \\
Rare but lethality up to $50 \%$
\end{tabular} & $\begin{array}{l}\text { All susceptible } \\
\text { without prior } \\
\text { infection }\end{array}$ & None & \begin{tabular}{|l} 
No second cases \\
identified, mild \\
infections. If \\
immunity exists \\
its duration and \\
strength are not \\
known
\end{tabular} & None & Deer mouse & $\begin{array}{l}\text { Another zoonosis, symptomatic } \\
\text { management only. }\end{array}$ \\
\hline Hendra and nipah viral diseases & $\begin{array}{l}\text { Paramyxoviruses } \\
\text { Nipah manifests primarily } \\
\text { as a encephalitis, Hendra } \\
\text { as a respiratory illness or a } \\
\text { prolonged and initially mild } \\
\text { encephalitis. } \\
\end{array}$ & Very restricted & $\begin{array}{l}\text { B33.8 } \\
\text { Rare but mortality up to } \\
50 \% \text {, subclinical infections } \\
\text { may be common! }\end{array}$ & All ages suceptible & $\begin{array}{l}\text { Those in contact with swine. Or } \\
\text { infected horses. Possibly people } \\
\text { in contact with palms sap from } \\
\text { trees with roosting bats. }\end{array}$ & $\begin{array}{l}\text { Recurrent infection } \\
\text { known. }\end{array}$ & none & \begin{tabular}{|l|} 
Fruit bats and a \\
variety of small \\
wild animals, \\
horses and some \\
companion \\
animals. \\
\end{tabular} & $\begin{array}{l}\text { Potentially very nasty zoonosis, } \\
\text { No specific treatment. }\end{array}$ \\
\hline \multicolumn{10}{|c|}{ Viral Hepatitis Diseases } \\
\hline $\begin{array}{l}\text { Viral Hepatitis A, infectious } \\
\text { hepatitis, Epidemic jaundice. }\end{array}$ & \begin{tabular}{|l} 
HAV a picornavirus (RNA) \\
All the hepatidides are \\
hepatropic and in various ways \\
impact on liver function.
\end{tabular} & $\begin{array}{l}\text { Worldwide } \\
(33 \% \text { of adults } \\
\text { in industrialised } \\
\text { countries are said } \\
\text { to have had contact } \\
\text { with it. }\end{array}$ & $\begin{array}{l}\text { B15 } \\
\text { Usually mild infection which } \\
\text { resolves in time } \\
\text { Case fatality low. Can reach } \\
1.8 \% \text { in adults over the age } \\
\text { of } 50 .\end{array}$ & General & $\begin{array}{l}\text { Number of epidemics among } \\
\text { school children particularly. } \\
\text { Homosexual males tend to } \\
\text { get it. Food handlers. Those } \\
\text { with chronic liver disease at } \\
\text { higher risk of bad outcome if } \\
\text { infection. }\end{array}$ & $\begin{array}{l}\text { Homologous } \\
\text { immunity after } \\
\text { infection probably } \\
\text { life long }\end{array}$ & $\begin{array}{l}\text { Two inactivated } \\
\text { vaccines are } \\
\text { available and } \\
\text { said to be } \\
\text { effective }\end{array}$ & \begin{tabular}{|l|} 
Humans, \\
more rarely \\
chimpanzees and \\
other animals \\
but an animal \\
reservoir in \\
nature has not \\
been recognized. \\
\end{tabular} & $\begin{array}{l}\text { A major disease but not in } \\
\text { the same league as some of its } \\
\text { alphabetic colleagues. Passive } \\
\text { immunisation with Ig is used. }\end{array}$ \\
\hline
\end{tabular}




\begin{tabular}{|c|c|c|c|c|c|c|c|c|c|}
\hline $\begin{array}{l}\text { Viral Hepatitis B, serum hepatitis, } \\
\text { homologous serum jaundice, } \\
\text { Australia antigen hepatitis }\end{array}$ & $\begin{array}{l}\text { HBV a double stranded DNA } \\
\text { virus } \\
\text { Fewer than } 10 \% \text { of children } \\
\text { and } 30-50 \% \text { of adults having } \\
\text { acute infection with HBV show } \\
\text { icteric disease. In infants it is } \\
\text { usually asymptomatic. }\end{array}$ & $\begin{array}{l}\text { World-wide. } \\
\text { It is written that } \\
2 \text { billion people } \\
\text { are infected and } \\
\text { that approximately } \\
600,000 \text { die each } \\
\text { year of the disease } \\
\text { with four million } \\
\text { new cases a year. }\end{array}$ & B16 & $\begin{array}{l}\text { Generalthough only } \\
\text { a small proportion of } \\
\text { cases are recognized. } \\
\text { (by icteric disease } \\
\text { usually) }\end{array}$ & $\begin{array}{l}\text { Immunosuppressed individuals } \\
\text { tend to get the chronic disease } \\
\text { with liver complications. } \\
\text { It is the prime cause of } \\
\text { hepatocellular carcinoma } \\
\text { that is second world-wide to } \\
\text { tobacco induced lung cancer. }\end{array}$ & $\begin{array}{l}\text { Vaccination is } \\
\text { widespread whether } \\
\text { spontaneous } \\
\text { immunity develops } \\
\text { following a recovered } \\
\text { infection is dependent } \\
\text { on the quality of } \\
\text { antibodies discovered. }\end{array}$ & $\begin{array}{l}\text { Effective } \\
\text { vaccines have } \\
\text { been available } \\
\text { for more than } \\
\text { twenty years. } \\
\text { One of these is } \\
\text { a recombinant } \\
\text { yeast which } \\
\text { expresses the } \\
\text { appropriate } \\
\text { antigen. } \\
\end{array}$ & $\begin{array}{l}\text { Humans perhaps } \\
\text { occasionally } \\
\text { chimpanzees. } \\
\text { Closely related } \\
\text { viruses from } \\
\text { other animals } \\
\text { do not affect } \\
\text { humans. }\end{array}$ & $\begin{array}{l}\text { The goliath among diseases. } \\
\text { Alpha interferon and } \\
\text { lamivudine but nothing which is } \\
\text { a guaranteed cure. }\end{array}$ \\
\hline Disease & $\begin{array}{l}\text { Infectious agent. } \\
\text { Target organ if any. }\end{array}$ & Location & $\begin{array}{l}\text { ICD } 10 \text { entry. } \\
\text { Impact }\end{array}$ & Susceptibility & Special risk factors & Immunity & Vaccines & \begin{tabular}{|l} 
Primary \\
reservoir and \\
vectors
\end{tabular} & Comments, treatment \\
\hline \begin{tabular}{|l|} 
Viral Hepatitis C, parenterally \\
transmitted nonAnonB hepatitis, \\
tranfusion associated hepatitis.
\end{tabular} & $\begin{array}{l}\text { HCV, an enveloped RNA virus } \\
\text { Onset insidious with only } \\
20-30 \% \text { of active infections } \\
\text { being symptomatic. } 75-85 \% \text { of } \\
\text { infections become chronic. }\end{array}$ & Worldwide & $\begin{array}{l}\text { B17.1 } \\
\text { Limited by the number of } \\
\text { people who share injection } \\
\text { equipment! For all that about } \\
1 \% \text { of the world population } \\
\text { are infected! (ie } 60 \text { million). }\end{array}$ & \begin{tabular}{|l|} 
General. The \\
enormous problem \\
here is that $90 \%$ \\
of infections are \\
asymptomatic. \\
Of those infected \\
a significant \\
number will get \\
cirrhosis of the liver \\
and sometimes \\
hepatocellular \\
carcinoma. Both these \\
conditions are gravely \\
life threatening. \\
\end{tabular} & $\begin{array}{l}\text { Drug users. Those using non- } \\
\text { sterile needles, recipientsof } \\
\text { transfused blood, unprotected } \\
\text { sex among male homosexuals. } \\
\text { Health care workers. }\end{array}$ & None recognized & None & $\begin{array}{l}\text { Humans. In } \\
\text { chimpanzees } \\
\text { experimental } \\
\text { re-infection } \\
\text { can be brought } \\
\text { about. but there } \\
\text { is no evidence } \\
\text { that non-human } \\
\text { primates act } \\
\text { areservoir of. } \\
\text { Human infection }\end{array}$ & $\begin{array}{l}\text { An effective treatment with } \\
\text { direct acting anti-viral } \\
\text { treatment is now available.(not } \\
\text { referred to in the } 20^{\text {th }} \text { editionof } \\
\text { the manual but recorded widely } \\
\text { on the web. }\end{array}$ \\
\hline Viral Hepatitis D, Delta hepatitis & $\begin{array}{l}\text { HDV a single stranded RNA } \\
\text { virus }\end{array}$ & Worldwide & \begin{tabular}{|l|} 
B17.1 About 10million \\
people affected worldwide \\
alwaysin conjunction with \\
HBV
\end{tabular} & General & $\begin{array}{l}\text { Severe disease can occur even } \\
\text { in children }\end{array}$ & Not stated & $\begin{array}{l}\text { HBV can lead } \\
\text { to immunity to } \\
\text { HDV. }\end{array}$ & Humans & $\begin{array}{l}\text { None given. For those with } \\
\text { established HBV infection there } \\
\text { are presently no methods to } \\
\text { prevent HDV }\end{array}$ \\
\hline $\begin{array}{l}\text { Viral Hepatitis E, epidemic, } \\
\text { nonA, nonB }\end{array}$ & $\begin{array}{l}\text { HEV a non- enveloped single } \\
\text { stranded RNA }\end{array}$ & worldwide & $\begin{array}{l}\text { B17.2 } \\
\text { Small in comparison with } \\
\text { A and B }\end{array}$ & $\begin{array}{l}\text { Susceptibility } \\
\text { unknown }\end{array}$ & $\begin{array}{l}\text { Pregnant women in the third } \\
\text { trimester of pregnancy are } \\
\text { particularly susceptible }\end{array}$ & Not stated. & None & \begin{tabular}{|l} 
?domestic \\
animals \\
including swine
\end{tabular} & None recorded \\
\hline Disease & $\begin{array}{l}\text { Infectious agent. } \\
\text { Target organ if any. }\end{array}$ & Location & $\begin{array}{l}\text { ICD } 10 \text { entry. } \\
\text { Impact }\end{array}$ & Susceptibility & Special risk factors & Immunity & Vaccines & $\begin{array}{l}\begin{array}{l}\text { Primary } \\
\text { reservoir and } \\
\text { vectors }\end{array} \\
\end{array}$ & Comments, treatment \\
\hline \begin{tabular}{|l|} 
Herpes simplex, anogenital \\
herpesviral infections, Congenital \\
herpes viral infection. \\
In addition, two other herpes \\
infections are listed which will \\
dealt with separately below. \\
\end{tabular} & \begin{tabular}{|l|} 
Herpes simplex virus land \\
2 (roughly 1 for the top end in \\
kids and 2 for the bottom in \\
adults, it being largely an STD) \\
Neurovirulence, latency and a \\
tendency to local recurrence \\
characterize these infections
\end{tabular} & $\begin{array}{l}\text { Worldwide, } 50-90 \% \\
\text { of adults possess } \\
\text { antibodies against } \\
\text { HSV 1 }\end{array}$ & \begin{tabular}{|l} 
A60, B00, P35.2 \\
Many primary infections \\
are inapparent and the \\
symptomatic cases vary a \\
great deal in severity in both \\
instances
\end{tabular} & Universal & Immunosuppressed individuals & $\begin{array}{l}\text { Antibodies are elicited } \\
\text { but they seem not } \\
\text { to be affected by } \\
\text { reactivation of latent } \\
\text { infection (or vice } \\
\text { versa!) }\end{array}$ & None quoted & Humans & $\begin{array}{l}\text { Remarkably contagious, } \\
\text { Acyclovir IV seems to be } \\
\text { reasonably effective. }\end{array}$ \\
\hline
\end{tabular}




\begin{tabular}{|c|c|c|c|c|c|c|c|c|c|}
\hline Kaposi's sarcoma & $\begin{array}{l}\text { KS associated herpes virus or } \\
\text { Herpes virus } 8 \text { believed to be } \\
\text { causal. } \\
\text { STD. though it is argued } \\
\text { that non-sexual means of } \\
\text { transmission also occur }\end{array}$ & $\begin{array}{l}\text { Where AIDS } \\
\text { patients are to } \\
\text { be found, i.e. } \\
\text { worldwide. }\end{array}$ & C46.0, C46.9 & ? & Immunosuppression & $\begin{array}{l}\text { Antibodies to the } \\
\text { virus are recognised } \\
\text { but it is not clear what } \\
\text { their relationship is to } \\
\text { clinical status. }\end{array}$ & & & $\begin{array}{l}\text { Associated largely with HIV } \\
\text { infections. }\end{array}$ \\
\hline $\begin{array}{l}\text { Influenza, human diseases and } \\
\text { zoonoses are recognised. }\end{array}$ & $\begin{array}{l}\text { Three types of virus some of } \\
\text { which are further broken down } \\
\text { but a main characteristic of } \\
\text { the organism is its capacity to } \\
\text { produce new variants. } \\
\text { Infection of the respiratory } \\
\text { tract }\end{array}$ & $\begin{array}{l}\text { In pandemics in } \\
\text { which a variable } \\
\text { proportion of } \\
\text { the population is } \\
\text { affected }\end{array}$ & $\begin{array}{l}\text { J10, J11. } \\
\text { as said to have killed up to } 50 \\
\text { million in the } 1918 \text { outbreak }\end{array}$ & $\begin{array}{l}\text { Complex picture, } \\
\text { implication is that all } \\
\text { are susceptible except } \\
\text { those who have had } \\
\text { a previous encounter } \\
\text { with the same or } \\
\text { similar organism }\end{array}$ & $\begin{array}{l}\text { Again, very variable. In some } \\
\text { epidemics more than } 80 \% \text { of } \\
\text { those who died were over the } \\
\text { age of } 65 \text { but in relation to the } \\
\text { biggest epidemic (in 1918) } \\
\text { young adults were the most } \\
\text { affected! }\end{array}$ & $\begin{array}{l}\text { Type specific } \\
\text { immunity is strong }\end{array}$ & $\begin{array}{l}\text { Inactivated virus } \\
\text { used widely } \\
\text { and it does give } \\
\text { protection. }\end{array}$ & \begin{tabular}{|l|} 
Humans primary \\
reservoir but \\
other spp. e.g. \\
aquatic birds \\
have widely \\
been mooted \\
as capable of \\
initiating a \\
pandemic.
\end{tabular} & $\begin{array}{l}\text { A major disease the impact } \\
\text { of which can be lessened by } \\
\text { vaccination. Oseltamivir and } \\
\text { Zanamivir both associated with } \\
\text { potential side effects }\end{array}$ \\
\hline $\begin{array}{l}\text { Other influenza., infections } \\
\text { circulating in and causingdiseases } \\
\text { in animals }\end{array}$ & $\begin{array}{l}\text { H5N1, avian influenza virus } \\
\text { and H9N2, swine influenza } \\
\text { virus. } \\
\text { Mortality can high among } \\
\text { humans infected with } \\
\text { the relevant viruses from } \\
\text { (diseased?) infected poultry } \\
\text { are the main focus in the } 20^{\text {th }} \\
\text { edition of the manual. }\end{array}$ & World wide & $\begin{array}{l}\text { J09 } \\
\text { All potential causes of } \\
\text { pandemics. The influenza } \\
\text { viruses are highly mutable } \\
\text { and always generate } \\
\text { antigenically new variants } \\
\text { which greatly complicates } \\
\text { the invention of prophylactic } \\
\text { vaccine preparation. }\end{array}$ & $\begin{array}{l}\text { Initially occupational } \\
\text { in that close contact } \\
\text { with infected animals } \\
\text { is a major risk } \\
\text { factor but pandemic } \\
\text { spread to the general } \\
\text { population is } \\
\text { always regarded as a } \\
\text { potential hazard. }\end{array}$ & $\begin{array}{l}\text { Potentially all ages can become } \\
\text { diseased. Immunity post } \\
\text { infection does occur and to a } \\
\text { limited extent can be induced } \\
\text { either with attenuated live } \\
\text { vaccines or non-living vaccines } \\
\text { against extracted components } \\
\text { of the virus responsible. }\end{array}$ & Inducible & $\begin{array}{l}\text { Some vaccines } \\
\text { against } \mathrm{H} 5 \mathrm{~N} 1 \\
\text { have been } \\
\text { prepared and } \\
\text { licensed for use. }\end{array}$ & \begin{tabular}{|l|} 
Uncertain \\
whether \\
migratory birds \\
are capable \\
of spreading \\
pathogenic \\
viruses either to \\
domestic animals \\
or to man.
\end{tabular} & As above. \\
\hline Disease & $\begin{array}{l}\text { Infectious agent. } \\
\text { Target organ if any. }\end{array}$ & Location & $\begin{array}{l}\text { ICD 10entry. } \\
\text { Impact }\end{array}$ & Susceptibility & Special risk factors & Immunity & Vaccines & \begin{tabular}{|l} 
Primary \\
reservoir and \\
vectors
\end{tabular} & Comments, treatment \\
\hline $\begin{array}{l}\text { Lymphocytic chorio-meningitis } \\
\text { virus, LCM, a viral infection of } \\
\text { rodents mainly mice. }\end{array}$ & $\begin{array}{l}\text { An envelopedambisense } \\
\text { RNAarena virus closely related } \\
\text { to lassa and a number of others } \\
\text { Variety of symptoms can be } \\
\text { influenza like. Rarely fatal. }\end{array}$ & $\begin{array}{l}\text { Not uncommon } \\
\text { in Europe and } \\
\text { America }\end{array}$ & $\begin{array}{l}\text { A87.2 } \\
\text { Rarely serious, extremely } \\
\text { variable in its presentation }\end{array}$ & $\begin{array}{l}\text { Not stated, } \\
\text { Implication is that } \\
\text { susceptibility is } \\
\text { universal }\end{array}$ & $\begin{array}{l}\text { Surprisingly, } \\
\text { immunosuppressed patients } \\
\text { who become infected may often } \\
\text { not show the usual symptoms. } \\
\text { Though in them the disease } \\
\text { can be fatal. Occupational risk. } \\
\text { Human foetuses can acquire } \\
\text { the infection vertically. }\end{array}$ & $\begin{array}{l}\text { Recovery leads to } \\
\text { lifelong infection. Cell } \\
\text { mediated immune } \\
\text { responses may play } \\
\text { a primary role, } \\
\text { antibodies are of lesser } \\
\text { importance }\end{array}$ & none & $\begin{array}{l}\text { Mus musculus, } \\
\text { the house mouse. } \\
\text { The disease in } \\
\text { man is a zoonosis }\end{array}$ & $\begin{array}{l}\text { Nude, immunologically } \\
\text { incompetent mice become } \\
\text { chronic shedders but do not } \\
\text { show disease. Ribavirin has } \\
\text { been proposedas treatment for } \\
\text { humans. A fascinating disease } \\
\text { for immunologists. }\end{array}$ \\
\hline Measles, rubeola & $\begin{array}{l}\text { Measles virus, a member of } \\
\text { the genus Morbillivirus. A } \\
\text { paramyxovirus Prodromal } \\
\text { fever and pathognomonic rash. } \\
\text { Rarely sub-acute sclerosing } \\
\text { panencephalitis develops as late } \\
\text { complication. }\end{array}$ & $\begin{array}{l}\text { Complex pattern } \\
\text { due to successful } \\
\text { vaccination } \\
\text { programs. Initially } \\
\text { it seemed to be a } \\
\text { disease of large } \\
\text { metropolitan } \\
\text { aggregates with a } \\
\text { two to three year } \\
\text { cycle. In rural } \\
\text { populations it } \\
\text { was less frequent } \\
\text { butmore severe }\end{array}$ & \begin{tabular}{|l|} 
B05 \\
Unimmunuized populations \\
can be extremely badly \\
effected with a high case- \\
fatality rate. World-wide \\
it was estimated that prior \\
to global vaccination \\
programs six million measles \\
deaths occurredeach year!. \\
However, it is recorded by \\
WHOO that in 2011 157,700 \\
children died. The anti- \\
vaccine activists should look \\
carefully at these figures.
\end{tabular} & $\begin{array}{l}\text { Universal (pace } \\
\text { immunisation) }\end{array}$ & $\begin{array}{l}\text { More severe in infants and } \\
\text { adults than in children } \\
\text { Malnutrition, vitamin A } \\
\text { deficiency predispose to } \\
\text { severe disease.vaccination not } \\
\text { recommended in those with } \\
\text { immunodeficiency disease. }\end{array}$ & $\begin{array}{l}\text { Lifelong immunity } \\
\text { after illness (issue } \\
\text { of development of } \\
\text { SSPE as a long term } \\
\text { outcome of measles } \\
\text { infection is not here } \\
\text { considered in detail) }\end{array}$ & $\begin{array}{l}\text { Immunisation } \\
\text { with a live } \\
\text { attenuated virus } \\
\text { is very effective. }\end{array}$ & Humans & \begin{tabular}{|l} 
In the developed world \\
essentially under control until \\
recently when resistance to \\
vaccination has begun to reduce \\
those who are immune. In days \\
gone by before vaccination more \\
than ninety per cent of people \\
had been infected before the age \\
of twenty. No specific treatment.
\end{tabular} \\
\hline
\end{tabular}




\begin{tabular}{|c|c|c|c|c|c|c|c|c|c|}
\hline Disease & \begin{tabular}{|l|} 
Infectious agent. \\
Target organ if any.
\end{tabular} & Location & $\begin{array}{l}\text { ICD } 10 \text { entry. } \\
\text { Impact }\end{array}$ & Susceptibility & Special risk factors & Immunity & Vaccines & $\begin{array}{l}\text { Primary reservoir } \\
\text { and vectors }\end{array}$ & \begin{tabular}{l|l} 
ir & Comments, treatment \\
\end{tabular} \\
\hline Molluscum contagiosum. & $\begin{array}{l}\text { Molluscipox virus a member of } \\
\text { the Poxviridae family. } \\
\text { Skin. }\end{array}$ & Worldwide & $\begin{array}{l}\text { B08.1 } \\
\text { More nuisance value }\end{array}$ & $\begin{array}{l}\text { General but specially } \\
\text { in children }\end{array}$ & $\begin{array}{l}\text { Lesions tend to disseminate in } \\
\text { HIV patients }\end{array}$ & ? & none & Humans & No specific treatment \\
\hline \multicolumn{10}{|c|}{$\begin{array}{l}\text { EPSTEIN-BARR INFECTIONS } \\
\text { Also associated with infection by this virus are several diseases of which Burkitt's lymphoma, nasopharyngeal carcinoma, Hodgkin's disease and various non-Hodgkins lymphomas are mentioned in the } 20^{\text {th }} \text { edition of the manual }\end{array}$} \\
\hline $\begin{array}{l}\text { Monoucleosis, infectious, } \\
\text { (glandular fever), }\end{array}$ & $\begin{array}{l}\text { EBV, a herpesvirus } 4 . \\
\text { It affects and transforms B cells. }\end{array}$ & $\begin{array}{l}\text { Worldwide } \\
\text { common, in early } \\
\text { childhood }\end{array}$ & \begin{tabular}{|l} 
B27Usually mild or \\
asymptomatic, about 50\% \\
of those infected develop \\
symptoms. All those infected \\
retain the virus in latent \\
(non-lytic) form for life and \\
the possession of the virus \\
is associated with many \\
malignant diseases. This \\
issue will not be dealt with in \\
any detail here
\end{tabular} & General & $\begin{array}{l}\text { May recur or be extremely } \\
\text { serious in immunodeficient } \\
\text { patients. (particularly X-linked } \\
\text { recessive immunoproliferative } \\
\text { disorder) Paradoxically, } \\
\text { recurrence can be associated } \\
\text { with the development of } \\
\text { anti EB antibodies but not } \\
\text { the array of heterophile } \\
\text { antibodies that has been used } \\
\text { aspathognomonic for the acute } \\
\text { disease. }\end{array}$ & $\begin{array}{l}\text { Infection incurs an } \\
\text { immune response, } \\
\text { despite which the } \\
\text { organism persists in } \\
\text { latent form for life. }\end{array}$ & None yet & 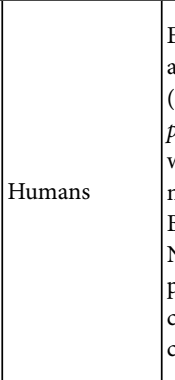 & $\begin{array}{l}\text { Extraordinary capacity to infect } \\
\text { and transform B-lymphocytes } \\
\text { (rather as can Theileria } \\
\text { parvaincattle). Also associated } \\
\text { with the development of } \\
\text { nasopharyngeal carcinoma and } \\
\text { Burkitt's lymphoma. } \\
\text { NST though the tumours, } \\
\text { particularly Burkitt's lymphoma } \\
\text { can be successfully treated in most } \\
\text { cases. }\end{array}$ \\
\hline Disease & $\begin{array}{l}\text { Infectious agent. } \\
\text { Target organ if any. }\end{array}$ & Location & $\begin{array}{l}\text { ICD } 10 \text { entry. } \\
\text { Impact }\end{array}$ & Susceptibility & Special risk factors & Immunity & Vaccines & \begin{tabular}{|l|l}
$\begin{array}{l}\text { Primary } \\
\text { reservoir and } \\
\text { vectors }\end{array}$ & \multicolumn{1}{c}{} \\
\end{tabular} & Comments, treatment \\
\hline Mumps, infectious parotitis & $\begin{array}{l}\text { A paramyxovirus } \\
\text { An acute fever and tenderness } \\
\text { of one or more of the salivary } \\
\text { glands. }\end{array}$ & $\begin{array}{l}\text { Worldwide, } \\
\text { about } 85 \% \text { of } \\
\text { unvaccinated } \\
\text { people have } \\
\text { antibodies by } \\
\text { adulthood. } \\
\end{array}$ & $\begin{array}{l}\text { B26 } \\
\text { About a third of } \\
\text { those infected remain } \\
\text { asymptomatic. Under the age } \\
\text { of two infections are almost } \\
\text { always subclinical. }\end{array}$ & $\begin{array}{l}\text { Not stated but } \\
\text { presumably universal }\end{array}$ & None indicated & \begin{tabular}{|l} 
Lifelong immunity \\
very often as a result \\
ofinapparent /latent? \\
infection
\end{tabular} & \begin{tabular}{|l|} 
A live attenuated \\
virus is widely \\
used
\end{tabular} & Humans & None \\
\hline \multicolumn{10}{|c|}{ 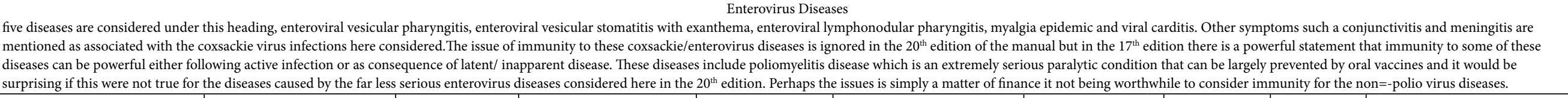 } \\
\hline $\begin{array}{l}2 \text { enteroviral vesicular } \\
\text { pharyngitis, herpangina }\end{array}$ & $\begin{array}{l}\text { Enterovirus A serotypes CV-A1 } \\
\text { to } 19,18,22 \text { and EV-A71. } \\
\text { Herbangina mildly febrile } \\
\text { illness with multiple painful } \\
\text { mouth ulcers. }\end{array}$ & & $\begin{array}{l}\text { B08.5Both this and } \\
\text { the following illness } \\
\text { have possibility of CNS } \\
\text { involvement with a } \\
\text { potentially fatal outcome }\end{array}$ & Young children & $\begin{array}{l}\text { Attendance at nursery schools, } \\
\text { day care centres, households } \\
\text { with many young children. }\end{array}$ & $\begin{array}{l}\text { No mention of } \\
\text { immunity and } \\
\text { recurrence is stated to } \\
\text { be common }\end{array}$ & None & Humans & Hygienic management \\
\hline $\begin{array}{l}\text { Enteroviral vesicular stomatitis } \\
\text { with exanthema, hand foot and } \\
\text { mouth disease }\end{array}$ & \begin{tabular}{|l|} 
Enterovirus A serotypes, CV- \\
A16 and EV71, less frequently \\
with enterovirus B serotype. \\
Skin, lesions usually heal \\
spontaneously without scarring
\end{tabular} & \begin{tabular}{|l|} 
Worldwide In \\
temperate regions \\
peak incidence is \\
in summer and \\
early autumn but \\
throughout the year \\
in the tropics. \\
\end{tabular} & $\begin{array}{l}\text { B08.4 } \\
\text { Typically, brief and mild } \\
\text { disease however see above }\end{array}$ & Young children & $\begin{array}{l}\text { Attendance at nursery schools, } \\
\text { day care centres, households } \\
\text { with many young children. }\end{array}$ & $\begin{array}{l}\text { No mention of } \\
\text { immunity. as } \\
\text { recurrence is common }\end{array}$ & None & Humans & Hygienic management \\
\hline
\end{tabular}




\begin{tabular}{|c|c|c|c|c|c|c|c|c|c|}
\hline Disease & \begin{tabular}{|l} 
Infectious agent. \\
Target organ if any.
\end{tabular} & Location & $\begin{array}{l}\text { ICD } 10 \text { entry. } \\
\text { Impact }\end{array}$ & Susceptibility & Special risk factors & Immunity & Vaccines & \begin{tabular}{|l|}
$\begin{array}{l}\text { Primary } \\
\text { reservoir and } \\
\text { vectors }\end{array}$ \\
\end{tabular} & Comments, treatment \\
\hline $\begin{array}{l}\text { enteroviral lymphonodular } \\
\text { pharyngitis }\end{array}$ & $\begin{array}{l}\text { Enterovirus A serotypeCV-A10 } \\
\text { skin }\end{array}$ & Worldwide & B08.8 & Young children & $\begin{array}{l}\text { The entries for the } 17^{\text {th }} \text { and } 20 \mathrm{t} \\
\text { edition of the manual differ } \\
\text { lymphonodular pharyngitis } \\
\text { though mentioned in the latter } \\
\text { is not further considered. } \\
\text { Whereas in the } 17^{\text {th }} \text { edition } \\
\text { there is come information } \\
\text { given Furthermore the } \\
\text { accounts ofthree of the diseases } \\
\text { mentionedin } 20^{\text {th }} \text { edition differ } \\
\text { greatly in relation to the issue } \\
\text { of immunity }\end{array}$ & ? & ? & ? & \\
\hline $\begin{array}{l}\text { Myalgia, epidemic, devil's grippe, } \\
\text { Bornholm's disease }\end{array}$ & $\begin{array}{l}\text { Group B coxsackie virus } \\
\text { Pleurodynia with paroxysmal } \\
\text { pain in chest and abdomen }\end{array}$ & uncommon & $\begin{array}{l}\text { B33.0 } \\
\text { Outbreaks in various parts } \\
\text { of the world, Europe, } \\
\text { Australia, New Zealand and } \\
\text { N Armerica }\end{array}$ & Probably general & None indicated & \begin{tabular}{|l} 
Specific immunity \\
presumably results \\
from infection \\
$17^{\text {th }}$ edition, none \\
mentioned in the $0^{20 \text { th }}$ \\
edition. \\
\end{tabular} & None & Humans & None \\
\hline Poliomyelitis, infantile paralysis & $\begin{array}{l}\text { Poliovirus, genus Enterovirus, } \\
\text { types } 1,2 \text { and } 3 \text { Paralysis of } \\
\text { varying degrees. Can occur. } \\
\text { Infection starts in the intestinal } \\
\text { tract with spread to regional } \\
\text { lymph nodes and more rarely } \\
\text { to the CNS. }\end{array}$ & \begin{tabular}{|l|} 
It was worldwide \\
now it is becoming \\
confined to India \\
and to a lesser \\
extent to parts of \\
Africa
\end{tabular} & $\begin{array}{l}\text { A } 80 \text { Has been a major } \\
\text { cause of partial paralysis. } \\
\text { About } 90 \% \text { of infections } \\
\text { are unapparent or result in } \\
\text { nonspecific fever. }\end{array}$ & Universal. & $\begin{array}{l}\text { High risk is for those who } \\
\text { for various reasons are not } \\
\text { immunized. immigrants, } \\
\text { refugees, rural, and urban poor } \\
\text { for example, and more recently } \\
\text { those influencedby the anti- } \\
\text { vaccine activists. }\end{array}$ & \begin{tabular}{|l} 
Type specific lifelong \\
immunity.
\end{tabular} & Very effective & $\begin{array}{l}\text { Humans with } \\
\text { inapparent } \\
\text { infections. } \\
\text { (also a few } \\
\text { chronic } \\
\text { shedder) }\end{array}$ & $\begin{array}{l}\text { Nearly eradicated but not quite. } \\
\text { The neurotropism demonstrated is } \\
\text { extraordinary.No treatment }\end{array}$ \\
\hline Disease & $\begin{array}{l}\text { Infectious agent. } \\
\text { Target organ if any. }\end{array}$ & Location & $\begin{array}{l}\text { ICD } 10 \text { entry. } \\
\text { Impact }\end{array}$ & Susceptibility & Special risk factors & Immunity & Vaccines & \begin{tabular}{|l|}
$\begin{array}{l}\text { Primary } \\
\text { reservoir and } \\
\text { vectors }\end{array}$ \\
\end{tabular} & Comments, treatment \\
\hline Rabies, hydrophobia, Lyssa & $\begin{array}{l}\text { Rabies virus a rhabdovirus of } \\
\text { the genus Lyssavirus } \\
\text { Progressive viral encephalitis } \\
\text { almost always fatal. }\end{array}$ & World wide & $\begin{array}{l}\text { A82 } \\
\text { Estimated } 55,000 \text { deaths } \\
\text { annually almost all in } \\
\text { developing countries. The } \\
\text { disease is almost invariably } \\
\text { fatal. }\end{array}$ & \begin{tabular}{|l|} 
All mammals are \\
susceptible though \\
humans are less so \\
than other animal \\
species; in the $17^{\text {th }}$ \\
edition of the manual \\
it is stated that only \\
$40 \%$ of Iranians bitten \\
by known rabid \\
animals developed \\
the disease. This \\
statement is not in the \\
$20^{\text {th }}$ edition? \\
\end{tabular} & None recorded & $\begin{array}{l}\text { If it is uniformly } \\
\text { lethal the issue of } \\
\text { immunity does not } \\
\text { arise. However it } \\
\text { is known that the } \\
\text { virus can be carried } \\
\text { asymptomatically by a } \\
\text { number of animal spp. }\end{array}$ & $\begin{array}{l}\text { Both passive } \\
\text { and active } \\
\text { immunisation } \\
\text { is practised } \\
\text { for those at } \\
\text { high risk. } \\
\text { Human rabies } \\
\text { anti immune } \\
\text { globulin is } \\
\text { administered } \\
\text { after bites. }\end{array}$ & \begin{tabular}{|l|} 
Many wild \\
and domestic \\
canidae. \\
There are also \\
several spp. of \\
insectivorous \\
bats that carry \\
the virus. Their \\
disease status \\
is not stated.
\end{tabular} & $\begin{array}{l}\text { Control over this disease has been } \\
\text { maintained in some countries by } \\
\text { strict quarantine regulations for } \\
\text { imported animals. Nowadays, in } \\
\text { some instances, vaccination has } \\
\text { allowed movement again under } \\
\text { strict control. The lethality of the } \\
\text { disease in man is so high that } \\
\text { it is almost the most feared of } \\
\text { zoonoses. } \\
\text { No treatment }\end{array}$ \\
\hline
\end{tabular}




\begin{tabular}{|c|c|c|c|c|c|c|c|c|c|}
\hline $\begin{array}{l}\text { Respiratory disease, acute viral } \\
\text { rhinitis, the common cold, } \\
\text { rhinitis or coryza }\end{array}$ & \begin{tabular}{|l|} 
Rhinoviruses of which there \\
are more than 100 serotypes \\
account for $20-40 \%$ of cases, \\
corona viruses account for \\
$10-15 \%$ and influenza accounts \\
for $10-15 \%$. The etiology of \\
common colds has only been \\
identified in $50 \%$ of cases!
\end{tabular} & \begin{tabular}{|l|} 
Worldwide both \\
endemic and \\
epidemic, seasonal
\end{tabular} & $\begin{array}{l}\text { J100 } \\
\text { Many people have } 1-6 \text { colds } \\
\text { annually, incidence highest } \\
\text { up to five years of age then } \\
\text { declining }\end{array}$ & $\begin{array}{l}\text { Universal, inapparent } \\
\text { and abortive } \\
\text { infections occur }\end{array}$ & $\begin{array}{l}\text { Nothing indicated apart from } \\
\text { age }\end{array}$ & $\begin{array}{l}\text { ? with so many known } \\
\text { causes and roughly } \\
\text { an equal number of } \\
\text { unknown ones the } \\
\text { issue of immunity is } \\
\text { complex }\end{array}$ & $\begin{array}{l}\text { Specific anti- } \\
\text { adenovirus } \\
\text { vaccination has } \\
\text { proved effective } \\
\text { but there is } \\
\text { nothing available } \\
\text { generally }\end{array}$ & Humans & NST \\
\hline $\begin{array}{l}\text { Respiratory disease, acute febrile } \\
\text { respiratory disease (excluding } \\
\text { Streptococcal pharyngitis). }\end{array}$ & $\begin{array}{l}\text { Para-influenza virus or, more } \\
\text { rarely RSV and a number of } \\
\text { other agents. }\end{array}$ & $\begin{array}{l}\text { Worldwide, } \\
\text { seasonal }\end{array}$ & \begin{tabular}{|l} 
J01-06, J1. \\
Nuisance except in the \\
elderly and young
\end{tabular} & $\begin{array}{l}\text { Universal, reinfection } \\
\text { is common }\end{array}$ & $\begin{array}{l}\text { Age, compromised cardiac, } \\
\text { pulmonary or immune systems. }\end{array}$ & \begin{tabular}{|l|}
$\begin{array}{l}\text { Transient immunity in } \\
\text { the form of circulating } \\
\text { antibodies }\end{array}$ \\
\end{tabular} & None recorded & Humans & \begin{tabular}{|l} 
Antibiotic treatment is to be \\
avoided! \\
NST
\end{tabular} \\
\hline Rubella, German measles & \begin{tabular}{|l} 
Rubella virus. \\
Usually a mild fever.
\end{tabular} & \begin{tabular}{|l|} 
Worldwide \\
universally endemic
\end{tabular} & \begin{tabular}{|l|} 
B06. \\
Usually, a mild febrile disease \\
\end{tabular} & $\begin{array}{l}\text { Universal after loss of } \\
\text { maternal antibodies }\end{array}$ & Fetuses & Long lasting immunity & Effective & Humans & $\begin{array}{l}\text { Important because of its capacity } \\
\text { to elicit fetal abnormalities. NST. }\end{array}$ \\
\hline Disease & $\begin{array}{l}\text { Infectious agent. } \\
\text { Target organ if any. }\end{array}$ & Location & $\begin{array}{l}\text { ICD } 10 \text { entry. } \\
\text { Impact }\end{array}$ & Susceptibility & Special risk factors & Immunity & Vaccines & \begin{tabular}{|l|} 
Primary \\
reservoir and \\
vectors
\end{tabular} & Comments, treatment \\
\hline \multicolumn{10}{|c|}{ 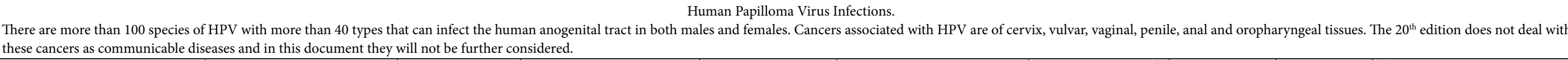 } \\
\hline $\begin{array}{l}\text { Warts, viral, common wart, } \\
\text { verruca vulgaris }\end{array}$ & $\begin{array}{l}\text { HPV } \\
\text { Skin andmucous membranes, }\end{array}$ & Worldwide & $\begin{array}{l}\text { B07A wide variety of } \\
\text { conditions most non-fatal }\end{array}$ & Common & $\begin{array}{l}\text { Young children for flat warts, } \\
\text { genital warts in sexually active } \\
\text { teenagers }\end{array}$ & \begin{tabular}{|l} 
Incidence of \\
warts higher in \\
immunosuppressed \\
individuals
\end{tabular} & None & Humans & NST, cryotherapy effective. \\
\hline Yellow fever & $\begin{array}{l}\text { A flavivirus } \\
\text { Variable outcome of infection } \\
\text { from mild fever to severe } \\
\text { disease with jaundice and } \\
\text { haemorrhage. }\end{array}$ & $\begin{array}{l}\text { A complex pattern } \\
\text { of disease falling } \\
\text { into two categories, } \\
\text { sylvatic (jungle)and } \\
\text { urban cycles }\end{array}$ & $\begin{array}{l}\text { A95 } \\
\text { a sporadic disease with } \\
\text { highbut very variable } \\
\text { lethality. At worst } 50 \% \text {. } \\
\text { The overall fatality rate in } \\
\text { endemic regions among } \\
\text { native populations is } 5 \% \text {. } \\
\text { Mild inapparent infections } \\
\text { are common. }\end{array}$ & $\begin{array}{l}\text { Presumably, } \\
\text { everybody, it does } \\
\text { not say }\end{array}$ & $\begin{array}{l}\text { Young adult males at } \\
\text { most occupational risk. } \\
\text { Unvaccinated travellers, } \\
\text { forest workers in endemic } \\
\text { areas. Disease is highly } \\
\text { communicable }\end{array}$ & \begin{tabular}{|l|} 
Single attack can \\
confer lifelong \\
immunity. Antibodies \\
appear in the first \\
week of infection. \\
Transient passive \\
immunity in new born \\
infants.
\end{tabular} & \begin{tabular}{|l} 
Extremely \\
effective live \\
vaccine.
\end{tabular} & $\begin{array}{l}\text { Humans and } \\
\text { mosquitos in } \\
\text { urban areas } \\
\text { in forest } \\
\text { areas almost } \\
\text { anything on } \\
\text { four legs. }\end{array}$ & No treatment cited. \\
\hline
\end{tabular}


Table 3: Protozoa (Protoctista)

\begin{tabular}{|c|c|c|c|c|c|c|c|c|}
\hline Disease & \begin{tabular}{|l} 
Infectious agent. \\
Target organ if any.
\end{tabular} & Location & \begin{tabular}{|l} 
ICD 10entry. \\
Impact
\end{tabular} & Susceptibility & Special risk factors & Immunity & \begin{tabular}{|l}
$\begin{array}{l}\text { Primary reservoir } \\
\text { and vectors }\end{array}$ \\
\end{tabular} & Comments, treatment? \\
\hline $\begin{array}{l}\text { In the } 20^{\text {th }} \text { edition of the manual } \\
\text { two amoebic disease patterns are } \\
\text { given the first called Amoebiasis, } \\
\text { amoebic dysentery and the second } \\
\text { rather different group listed below } \\
\text { all caused by free living organisms } \\
\end{array}$ & $\begin{array}{l}\text { Entomoeba histolytica } \\
\text { Initially gut but with chronic } \\
\text { infection more commonly and } \\
\text { sometimes liver abscess. }\end{array}$ & \begin{tabular}{|l} 
Ubiquitous more \\
prevalent in tropical \\
regions with poor \\
sanitation.
\end{tabular} & $\begin{array}{l}\text { A06 } \\
\text { Most infections said to be } \\
\text { symptomatic. Problems } \\
\text { presumably more for none } \\
\text { indigenous populations. }\end{array}$ & $\begin{array}{l}\text { General, persons of all ages } \\
\text { are susceptible. }\end{array}$ & $\begin{array}{l}\text { Conditions favouring move to } \\
\text { heightened pathogenicity stated } \\
\text { to exist but not specified }\end{array}$ & $\begin{array}{l}\text { Reinfection is rare implication } \\
\text { is that immunity once } \\
\text { acquired is long lasting. }\end{array}$ & n $\begin{array}{l}\text { Man, asymptomatic } \\
\text { cyst carriers are more } \\
\text { frequent than cyst } \\
\text { carriers with disease. }\end{array}$ & $\begin{array}{l}\text { Disease unusual in the } \\
\text { youngLargely a disease } \\
\text { of young adults. Most } \\
\text { infectionsasymptomatic, CTX } \\
\text { effective. }\end{array}$ \\
\hline $\begin{array}{l}\text { Naegleriasis, } \\
\text { acanthamoebiasis and } \\
\text { balamuthiasis }\end{array}$ & $\begin{array}{l}\text { Naegleria fowleri } \\
\text { Acanthamoeba(various spp,)and } \\
\text { Balamuthia mandrillari } \\
\text { Brain, encephalitis }\end{array}$ & Global & $\mathrm{B} 60.2, \mathrm{~B} 60.1$ & \begin{tabular}{|l|} 
NK both \\
immunocompetent \\
and immunodeficient \\
individuals have been \\
recorded with these \\
diseases. \\
\end{tabular} & $\begin{array}{l}\text { Swimming in warm fresh water. } \\
\text { Individuals with contact lenses }\end{array}$ & $\begin{array}{l}\text { NK. No indication is given } \\
\text { of asymptomatic infected } \\
\text { individuals }\end{array}$ & $\begin{array}{l}\text { Free living Amoebae } \\
\text { in soil and water. }\end{array}$ & $\begin{array}{l}\text { Diseases caused have over } \\
90 \% \text { lethality but seem to } \\
\text { be rare. }\end{array}$ \\
\hline Disease & \begin{tabular}{|l|} 
Infectious agent. \\
Target organ if any.
\end{tabular} & Location & $\begin{array}{l}\text { ICD } 10 \text { entry. } \\
\text { Impact }\end{array}$ & Susceptibility & Special risk factors & Immunity & \begin{tabular}{|l|}
$\begin{array}{l}\text { Primary reservoir } \\
\text { and vectors }\end{array}$ \\
\end{tabular} & Comments, treatment? \\
\hline Babesiosis, no synonym & $\begin{array}{l}\text { Babesismicrotisis most common of } \\
\text { several spp. involved. } \\
\text { Symptoms very variable but non- } \\
\text { specific fever common }\end{array}$ & $\begin{array}{l}\text { Worldwide in } \\
\text { scattered locations, } \\
\text { most in USA. }\end{array}$ & \begin{tabular}{|l|} 
B60.0 \\
Restricted largely it seems \\
by prevalence or control of \\
tick vectors \\
\end{tabular} & universal & $\begin{array}{l}\text { Asplenic, immunocompromised } \\
\text { and elderly people are at highest } \\
\text { risk. }\end{array}$ & Not written about. & $\begin{array}{l}\text { Rodents and cattle., } \\
\text { tick vectors. }\end{array}$ & \begin{tabular}{|l} 
Recrudescence of symptoms \\
after prolonged asymptomatic \\
parasitaemia can occur. CTX \\
but not always easy
\end{tabular} \\
\hline Balantidiasis,balantidialdystentery & $\begin{array}{l}\text { Balantidium coliColon with } \\
\text { dysentery. } \\
\text { Symptoms very variable } \\
\end{array}$ & \begin{tabular}{|l|} 
Worldwide \\
.Incidence of human \\
disease low. \\
\end{tabular} & A07.0 & $\begin{array}{l}\text { Humans seem to have high } \\
\text { natural resistance. }\end{array}$ & $\begin{array}{l}\text { Other medical conditions can } \\
\text { predispose to fatal disease. }\end{array}$ & $\begin{array}{l}\text { what is the basis of the } \\
\text { resistance? }\end{array}$ & \begin{tabular}{|l|}
$\begin{array}{l}\text { Swine and rats } \\
\text { laboratory pigs and } \\
\text { non-human primates. }\end{array}$ \\
\end{tabular} & $\begin{array}{l}\text { Antibiotics of various kinds. } \\
\text { Keep away from hog faeces! }\end{array}$ \\
\hline Cryptosporidiosis & $\begin{array}{l}\text { Cryptosporidiumhiminis and C. } \\
\text { parvum } \\
\text { Epithelial cells of the GI tract. } \\
\text { Diarrhoea most usual symptom } \\
\end{array}$ & Worldwide. & $\begin{array}{l}\text { A07.2 Low incidence of } \\
\text { disease but occasional } \\
\text { epidemics }\end{array}$ & $\begin{array}{l}\text { General but particularly im- } \\
\text { munodeficientindividuals. }\end{array}$ & \begin{tabular}{|l|} 
Children younger than 2 years. \\
Animal handlers. Men who have \\
sex with men. Close contacts \\
with infected individuals
\end{tabular} & None indicated. & \begin{tabular}{|l|}
$\begin{array}{l}\text { Humans and } \\
\text { various animals. The } \\
\text { organisms infect a } \\
\text { large no. of spp. }\end{array}$ \\
\end{tabular} & $\begin{array}{l}\text { Nitazoxanide can be used. } \\
\text { For children older than one. }\end{array}$ \\
\hline Disease & \begin{tabular}{|l|} 
Infectious agent. \\
Target organ if any.
\end{tabular} & Location & $\begin{array}{l}\text { ICD 10entry. } \\
\text { Impact }\end{array}$ & Susceptibility & Special risk factors & Immunity & $\begin{array}{l}\text { Primary reservoir } \\
\text { and vectors }\end{array}$ & Comments, treatment? \\
\hline Giardiasis, giardia enteritis & $\begin{array}{l}\text { Giardia lamblia } \\
\text { Mainly of the upper intestine. }\end{array}$ & Worldwide & $\begin{array}{l}\text { A07.1 } \\
\text { Not major }\end{array}$ & \multirow{3}{*}{$\begin{array}{l}\text { Asymptomatic carrier rate } \\
\text { is high, and most infections } \\
\text { are asymptomatic. } \\
\text { Infections are commonly } \\
\text { self-limiting. } \\
\text { Infected individuals } \\
\text { commonly have long } \\
\text { asymptomatic periods but } \\
\text { reactivation can occur. } \\
\text { Inapparentand subclinical } \\
\text { infections are common }\end{array}$} & $\begin{array}{l}\text { Children rather than adults. } \\
\text { Persons with AIDS may have } \\
\text { a more severe and prolonged } \\
\text { infection }\end{array}$ & $\begin{array}{l}\text { Not mentioned! Implication } \\
\text { from HIV association is that } \\
\text { immunity is involved but no } \\
\text { indication that this is adaptive } \\
\text { andor innate. }\end{array}$ & \begin{tabular}{|l} 
Humans possibly \\
beaver and other \\
wild and domestic \\
animals.
\end{tabular} & $\begin{array}{l}\text { Contaminated water is usual } \\
\text { source of primary infections. } \\
\text { Metronidazole usually works. }\end{array}$ \\
\hline $\begin{array}{l}\text { Leishmaniasis, Aleppo evil, } \\
\text { Baghdad or Delhi boil }\end{array}$ & $\begin{array}{l}\text { Leishmania tropicaand others } \\
\text { cutaneous mucosal here } \\
\text { recognized. }\end{array}$ & $\begin{array}{l}\text { Large number of } \\
\text { tropical and semi- } \\
\text { tropical locales, }\end{array}$ & \begin{tabular}{|l} 
B55.1, B55.2, Reasonably \\
common - about a \\
million new cases per \\
year reported. Not usually \\
dangerous
\end{tabular} & & $\begin{array}{l}\begin{array}{l}\text { Factors relating to late } \\
\text { development of severe disease } \\
\text { not known. }\end{array} \\
\end{array}$ & \begin{tabular}{|l|} 
Antibody levels low or non- \\
existent but lifelong immunity \\
can be created that is said \\
to have a powerful cellular \\
component
\end{tabular} & \begin{tabular}{|l|} 
Many, humans, \\
rodents, hyraxes, \\
sloths. unknown host \\
in many areas
\end{tabular} & СTX usually effective. \\
\hline Leishmaniasis, visceral, Kala-Azar & $\begin{array}{l}\text { Leishmania donovaniiand } \\
\text { othersFever with a wide variety of } \\
\text { subsequent symptoms. }\end{array}$ & $\begin{array}{l}\text { A rural disease } \\
\text { occurring in } \\
\text { foci in India and } \\
\text { Bangladesh }\end{array}$ & $\begin{array}{l}\text { B55.0.Usually fatalif } \\
\text { untreated }\end{array}$ & & & \begin{tabular}{|l} 
Infection can predispose \\
to lifelong homologous \\
immunity
\end{tabular} & $\begin{array}{l}\text { Humans and wild } \\
\text { and domestic dogs }\end{array}$ & $\begin{array}{l}\text { CTX available but it may } \\
\text { require prolonged application. }\end{array}$ \\
\hline & & & & & & & & \\
\hline
\end{tabular}




\begin{tabular}{|c|c|c|c|c|c|c|c|c|}
\hline Disease & \begin{tabular}{|l|} 
Infectious agent. \\
Target organ if any.
\end{tabular} & Location & $\begin{array}{l}\text { ICD } 10 \text { entry. } \\
\text { Impact }\end{array}$ & Susceptibility & Special risk factors & Immunity & \begin{tabular}{|l|} 
Primary reservoir \\
and vectors
\end{tabular} & Comments, treatment? \\
\hline Malaria, & $\begin{array}{l}\text { Plasmodium spp } \\
\text { An acute febrile illness with } \\
\text { a wide variety of subsequent } \\
\text { outcomes depending } \\
\text { mainly on the infective sp.of } \\
\text { P.falciparumthisisparticular is } \\
\text { usually lethal if untreated. Disease } \\
\text { due to P.vivaxP.malariaeand } P \text {. } \\
\text { ovaleare considered less } \\
\text { dangerous. }\end{array}$ & $\begin{array}{l}\text { In all tropical and } \\
\text { some subtropical } \\
\text { regions }\end{array}$ & $\begin{array}{l}\text { B50-B54 } \\
\text { Major cause of disease } \\
\text { where it occurs.. in } 2010 \\
99 \text { countries report on } \\
\text { goingmalaria transmission } \\
\text { with an estimated } 219 \mathrm{~m} \\
\text { cases and } 600,00 \text { deaths } \\
\text { mostly in young children } \\
\text { in Africa }\end{array}$ & $\begin{array}{l}\text { except in some } \\
\text { human beingswith the } \\
\text { sickle cell gene, in relation } \\
\text { to } \text { Pfalciparum or with } \\
\text { absence of Duffy factor } \\
\text { (P.vivax) }\end{array}$ & None quoted & \begin{tabular}{|l} 
Tolerance or \\
refractoriness to subsequent \\
clinical disease is present in \\
adults in endemic regions. \\
This could mean they are \\
immune? Are they free from \\
infection? Certainly repeated \\
infections are normal for \\
many of the indigenous \\
population.
\end{tabular} & $\begin{array}{l}\text { Humans, vector } \\
\text { mosquitoes }\end{array}$ & $\begin{array}{l}\text { This is a massive disease and } \\
\text { the account given leaves many } \\
\text { questions unanswered. }\end{array}$ \\
\hline $\begin{array}{l}\text { Pneumonia, immunodeficient } \\
\text { pneumonia }\end{array}$ & $\begin{array}{l}\text { Pneumocystis carinii (is it } \\
\text { a protozoan or a fungus?) } \\
\text { Acute,sub-acute condition which } \\
\text { can be fatal }\end{array}$ & All continents & \begin{tabular}{|l|} 
B59 \\
Persists sub clinically \\
in many instances. \\
Can be lethal in \\
immunosuppressed \\
individuals \\
\end{tabular} & $\begin{array}{l}\text { Again, there is the question } \\
\text { of whether we are talking } \\
\text { about susceptibility to } \\
\text { infection or disease. The } \\
\text { infection is usual the } \\
\text { disease is not. }\end{array}$ & $\begin{array}{l}\text { May be endemic and epidemic } \\
\text { in debilitated infants. It affected } \\
60 \% \\
\text { of AIDS patients in the USA } \\
\text { before prophylactic measures } \\
\text { were instituted. } \\
\end{array}$ & $\begin{array}{l}\text { If immunodeficiency } \\
\text { predisposes then it must be } \\
\text { supposed that normal control } \\
\text { is exercised by the immune } \\
\text { response. }\end{array}$ & \begin{tabular}{|l|} 
Humans. It is found \\
in many animal \\
species, but this is not \\
considered significant \\
in relation to human \\
disease. \\
\end{tabular} & $\begin{array}{l}\text { It is now believed that the } \\
\text { organism is a fungus. CTX } \\
\text { available. }\end{array}$ \\
\hline Disease & \begin{tabular}{|l|} 
Infectious agent. \\
Target organ if any.
\end{tabular} & Location & $\begin{array}{l}\text { ICD } 10 \text { entry. } \\
\text { Impact }\end{array}$ & Susceptibility & Special risk factors & Immunity & $\begin{array}{l}\text { Primary reservoir } \\
\text { and vectors }\end{array}$ & Comments, treatment? \\
\hline $\begin{array}{l}\text { Toxoplasmosis, and congenital } \\
\text { toxoplasmosis. }\end{array}$ & Toxoplasma gondii, a coccidian. & $\begin{array}{l}\text { Worldwide in birds } \\
\text { and mammals, } \\
\text { infection in humans } \\
\text { is common. }\end{array}$ & \begin{tabular}{|l|} 
B 58 congenital \\
versionacquired \\
transplacentally from \\
infected mothers P37.1 \\
Infections frequently \\
asymptomatic \\
\end{tabular} & General & $\begin{array}{l}\text { Immunosuppression can lead to } \\
\text { reactivation of infection. }\end{array}$ & $\begin{array}{l}\text { Immunity is readily acquired, } \\
\text { and most infections are } \\
\text { asymptomatic. The indication } \\
\text { is that the parasite persists }\end{array}$ & $\begin{array}{l}\text { Cats are the definitive } \\
\text { host }\end{array}$ & $\begin{array}{l}\text { Treatment for healthy } \\
\text { individuals not normally } \\
\text { indicated.AIDS patients } \\
\text { treated prophylactically. }\end{array}$ \\
\hline Trichomoniasis & $\begin{array}{l}\text { Trichomonas vaginalis } \\
\text { STD }\end{array}$ & $\begin{array}{l}\text { Widespread a disease } \\
\text { of all continents } \\
\text { and races. The most } \\
\text { common curable } \\
\text { STD }\end{array}$ & $\begin{array}{l}\text { A59 } \\
\text { Frequently asymptomatic }\end{array}$ & Universal & $\begin{array}{l}\text { Frequently asymptomatic. } \\
\text { Immunocompromised } \\
\text { individuals at greater risk. }\end{array}$ & None written of & Humans & $\begin{array}{l}\text { Metronidazole usually } \\
\text { effective }\end{array}$ \\
\hline $\begin{array}{l}\text { Trypanosomiasis, African, } \\
\text { sleeping sickness }\end{array}$ & $\begin{array}{l}\text { Trypanosoma brucei } \\
\text { gambiensisand T Rhodesiense } \\
\text { Systemic. }\end{array}$ & \begin{tabular}{|l|} 
Confined to regions \\
of tropical Africa \\
where lurks the \\
tsetse fly
\end{tabular} & $\begin{array}{l}\text { B56 In endemic regions } \\
\text { parasitaemia present in } \\
0.1-0.2 \% \text { of population } \\
\text { but during an epidemic } \\
\text { the figure can reach } 70 \% . \\
\text { Both forms of the disease } \\
\text { are fatal. } \\
\end{array}$ & $\begin{array}{l}\text { General. Though } \\
\text { spontaneous recovery has } \\
\text { been claimed it has not } \\
\text { been validated. }\end{array}$ & $\begin{array}{l}\text { No particular risk factors given. } \\
\text { Congenital transmissions can } \\
\text { occur. }\end{array}$ & $\begin{array}{l}\text { Various manifestations of } \\
\text { activation of the immune } \\
\text { apparatus are in evidence } \\
\text { but immunity does not seem } \\
\text { to arise. }\end{array}$ & $\begin{array}{l}\text { Humans for } \\
\text { gambiense but } \\
\text { wild ungulates for } \\
\text { Rhodesiense. Vector } \\
\text { is various spp. of } \\
\text { Glossinia }\end{array}$ & $\begin{array}{l}\text { CTX available but relapses } \\
\text { can occur. Part of the problem } \\
\text { seems to be that the drugs } \\
\text { used do not cross the blood } \\
\text { brain barrier. }\end{array}$ \\
\hline Disease & \begin{tabular}{|l} 
Infectious agent. \\
Target organ if any.
\end{tabular} & Location & $\begin{array}{l}\text { ICD } 10 \text { entry. } \\
\text { Impact }\end{array}$ & Susceptibility & Special risk factors & Immunity & $\begin{array}{l}\text { Primary reservoir } \\
\text { and vectors }\end{array}$ & Comments, treatment? \\
\hline $\begin{array}{l}\text { Trypanosomiasis, American, } \\
\text { Chagas Disease. }\end{array}$ & $\begin{array}{l}\text { T cruzi } \\
\text { systemic }\end{array}$ & $\begin{array}{l}\text { S.and Central } \\
\text { America }\end{array}$ & $\begin{array}{l}\text { B57No figures are given } \\
\text { on prevalence but the } \\
\text { disease is potentially } \\
\text { very nasty with a whole } \\
\text { series of complex } \\
\text { essentially autoimmune } \\
\text { manifestations. }\end{array}$ & $\begin{array}{l}\text { All ages susceptible but the } \\
\text { disease is more severe in the } \\
\text { young. Proportion clearing } \\
\text { the infection not quoted. }\end{array}$ & $\begin{array}{l}\text { Immunosuppressed individuals } \\
\text { are said to have greater chance } \\
\text { of severe disease }\end{array}$ & Nothing said about it. & $\begin{array}{l}\text { Humans and } 150 \mathrm{spp} \\
\text { of animals. Vector } \\
\text { for man is the cone } \\
\text { nosed bug. In the bug } \\
\text { the parasite persists } \\
\text { for life. }\end{array}$ & $\begin{array}{l}\text { CTX available for acute } \\
\text { disease. Nothing indicated for } \\
\text { chronic infections. }\end{array}$ \\
\hline
\end{tabular}


Table 4: Fungi (no vaccines recorded).

\begin{tabular}{|c|c|c|c|c|c|c|c|c|}
\hline Disease & $\begin{array}{l}\text { Infectious agent.Target } \\
\text { organ if any. }\end{array}$ & Location & $\begin{array}{l}\text { ICD 10entry. } \\
\text { Impact }\end{array}$ & Susceptibility & Special risk factors & Immunity & $\begin{array}{l}\text { Primary reservoir } \\
\text { and Vectors }\end{array}$ & Comments, treatable? \\
\hline Aspergillosis & $\begin{array}{l}\text { Aspergillus fumigatus } \\
\text { andA. flavus } 40 \mathrm{spp} \\
\text { have been reported as } \\
\text { infectious. } \\
\text { Lungs, initially. }\end{array}$ & $\begin{array}{l}\text { Worldwide though } \\
\text { uncommon and } \\
\text { sporadic }\end{array}$ & $\begin{array}{l}\text { B44 } \\
\text { Naturally, slight. }\end{array}$ & $\begin{array}{l}\text { The disease is usually secondary to a } \\
\text { primary condition. This it is claimed, } \\
\text { in conjunction with the ubiquity of } \\
\text { the fungal spores indicates that most } \\
\text { individuals are resistant }\end{array}$ & $\begin{array}{l}\text { Immunosuppression, } \\
\text { particularly prolonged } \\
\text { neutropenia. } \\
\text { Contact with aflotoxins }\end{array}$ & $\begin{array}{l}\text { Natural immunity claimed. } \\
\text { There is no indication of } \\
\text { activation of adaptive immune } \\
\text { mechanisms. }\end{array}$ & $\begin{array}{l}\text { Aspergillus spp. are } \\
\text { ubiquitous in nature }\end{array}$ & $\begin{array}{l}\text { Invasive forms of the } \\
\text { disease in immuno- } \\
\text { impairedindividualsbecome } \\
\text { the problem.. Treatment, of } \\
\text { Allergic disease is by prolonged } \\
\text { corticosteroid suppression. } \\
\text { Treatment far from simple. }\end{array}$ \\
\hline Blastomycosis, Gilchrist disease & $\begin{array}{l}\text { Blastomyces dermatidis } \\
\text { lungs }\end{array}$ & Rare & $\begin{array}{l}\text { B40Sporadic in Central and } \\
\text { Southern USA, Canada, Africa } \\
\text { India, Israel and Saudi Arabia. } \\
\text { Untreated chronicinfections } \\
\text { often eventually lethal }\end{array}$ & \begin{tabular}{|l|} 
Unknown but rarity of the natural \\
disease and of laboratory infections \\
suggests most people are relatively \\
resistant \\
Immunocompromised patients at \\
higher risk of disease.
\end{tabular} & $\begin{array}{l}\text { Rare in children, more common } \\
\text { in males than in females. Disease } \\
\text { in dogs is frequent also in such } \\
\text { rarities as a horse, a captive } \\
\text { African Lion and a sea lion. }\end{array}$ & $\begin{array}{l}\text { In apparentpulmonary } \\
\text { infections are probable. There is } \\
\text { evidence that CMI plays a role } \\
\text { in controlling lung infection }\end{array}$ & $\begin{array}{l}\text { Moist soil.Companion } \\
\text { animals susceptible } \\
\text { butzoonosis not } \\
\text { recorded. }\end{array}$ & $\begin{array}{l}\text { Acute disease often lasts three } \\
\text { weeks before resolving.Evolution } \\
\text { into a chronic disease is common. } \\
\text { CTXavailable }\end{array}$ \\
\hline Disease & \begin{tabular}{|l|} 
Infectious agent. \\
Target organ if any.
\end{tabular} & Location & $\begin{array}{l}\text { ICD } 10 \text { entry. } \\
\text { Impact }\end{array}$ & Susceptibility & Special risk factors & Immunity & $\begin{array}{l}\text { Primary reservoir } \\
\text { and Vectors }\end{array}$ & Comments, treatable? \\
\hline Candidiasis, moniliasis, thrush. & $\begin{array}{l}\text { Candida albicans }+ \text { other } \\
\text { spp. } \\
\text { Skin, mucous } \\
\text { membranes }\end{array}$ & $\begin{array}{l}\text { Worldwide. Candida } \\
\text { is a part of the normal } \\
\text { flora,is this to be } \\
\text { called an in apparent } \\
\text { infection? }\end{array}$ & $\begin{array}{l}\text { B37Big problems in those with } \\
\text { illness of a wide variety of kinds, } \\
\text { diabetes mellitus therapy with } \\
\text { broad spectrum antibiotics HIV } \\
\text { infection and so on. }\end{array}$ & $\begin{array}{l}\text { Either high immunity or low level } \\
\text { pathogenicity! }\end{array}$ & $\begin{array}{l}\text { Many debilitating diseases can } \\
\text { predispose to creating candida } \\
\text { problems. }\end{array}$ & $\begin{array}{l}\text { Most adults and older } \\
\text { children have delayed type } \\
\text { hypersensitivity and humoral } \\
\text { antibodies. }\end{array}$ & humans & $\begin{array}{l}\text { Fascinating organism. It clearly } \\
\text { occupies a niche probably in } \\
\text { balance with other organisms. }\end{array}$ \\
\hline $\begin{array}{l}\text { Chromomycosis, } \\
\text { dermatitis verrucosa. }\end{array}$ & \begin{tabular}{|l|} 
About ten species \\
involved including \\
Phialophoraverrucosa \\
skin
\end{tabular} & World wide & B43 & $\begin{array}{l}\text { Suggestion is that relative rarity } \\
\text { indicates a degree of resistance. The } \\
\text { absence of laboratory infections is } \\
\text { regarded as confirmation. }\end{array}$ & $\begin{array}{l}\text { Associated with men aged } 30- \\
50 \text { only rarely seen in women. } \\
\text { Barefoot workers are at higher } \\
\text { risk }\end{array}$ & ? & $\begin{array}{l}\text { Rotting wood and } \\
\text { in general decaying } \\
\text { vegetation }\end{array}$ & $\begin{array}{l}\text { A minor problem except for } \\
\text { those that get it. CTX available } \\
\text { plus sometimes surgery to } \\
\text { remove large lesions. }\end{array}$ \\
\hline $\begin{array}{l}\text { Coccidioidomycosis, valley fever, } \\
\text { San Joaquin fever, Desert fever. }\end{array}$ & $\begin{array}{l}\text { Coccidioides immitis } \\
<1 \% \text { of symptomatic } \\
\text { cases becomedissemi- } \\
\text { natedLung probably site } \\
\text { of entry }\end{array}$ & $\begin{array}{l}\text { Only in arid regions of } \\
\text { Western Hemisphere }\end{array}$ & $\begin{array}{l}\text { B38 } \\
\text { Important disease among } \\
\text { archaeologists, migrant workers } \\
\text { andmilitary personnel from } \\
\text { non-endemic areas }\end{array}$ & \begin{tabular}{|l|} 
Affects all ages, all races and both \\
genders. More than half patients \\
are between 15 and 25 years of age. \\
Susceptibility to dissemination is \\
greater among African Americans, \\
Filipinos and other Asians. Pregnant \\
women are at particular risk. AIDS \\
is a risk factor
\end{tabular} & $\begin{array}{l}\text { Males more frequently affected } \\
\text { than females (occupational } \\
\text { exposure is suggested). } \\
\text { Reactivation of latent infection } \\
\text { can occurif immunosuppression } \\
\text { arises }\end{array}$ & $\begin{array}{l}\text { High frequency of subclinical } \\
\text { infections felt to be the case. } \\
\text { Recovery from infection is } \\
\text { associated with solid lifelong } \\
\text { immunity }\end{array}$ & $\begin{array}{l}\text { Soil especially around } \\
\text { Indian middens and } \\
\text { rodent burrows. }\end{array}$ & $\begin{array}{l}\text { Infects almost any animal it } \\
\text { seems but not transmitted from } \\
\text { them to other animals or to man } \\
\text { or vice versa. Primary infection } \\
\text { usually responds without } \\
\text { treatment but in severe cases } \\
\text { CTX does exist. }\end{array}$ \\
\hline Disease & \begin{tabular}{|l|} 
Infectious agent. \\
Target organ if any.
\end{tabular} & Location & $\begin{array}{l}\text { ICD } 10 \text { entry. } \\
\text { Impact }\end{array}$ & Susceptibility & Special risk factors & Immunity & $\begin{array}{l}\text { Primary reservoir } \\
\text { and Vectors }\end{array}$ & Comments, treatable? \\
\hline Cryptococcosis, Torula. & $\begin{array}{l}\text { Cryptococcus neoformans } \\
\text { Lungs, point of entry. } \\
\text { Secondaries in the brain } \\
\text { can be lethal. }\end{array}$ & $\begin{array}{l}\text { Sporadic infections in } \\
\text { all parts of the world. } \\
\text { Classic example of an } \\
\text { organism that very } \\
\text { rarely causes problems } \\
\text { except in impaired } \\
\text { individuals }\end{array}$ & $\begin{array}{l}\text { B45 } \\
\text { Slight except with } \\
\text { immunosuppressed individuals }\end{array}$ & $\begin{array}{l}\text { Suggestion is that there is resistance. } \\
\text { This is based on rarity of the disease } \\
\text { and the ubiquity of the organism }\end{array}$ & $\begin{array}{l}\text { Males more than females, } \\
\text { Immunosuppression AIDS is a } \\
\text { risk factor. Hodgkins disease and } \\
\text { sarcoidosis }\end{array}$ & $\begin{array}{l}\text { No immunity written of in the } \\
\text { manual, but there are many } \\
\text { papers published that argued } \\
\text { both innate and adaptive } \\
\text { immune mechanisms are } \\
\text { active. Antibodies are however } \\
\text { not mentioned. }\end{array}$ & $\begin{array}{l}\text { Pigeons and old } \\
\text { pigeon roosts }\end{array}$ & $\begin{array}{l}\text { Secretes poly mannose that } \\
\text { presents problems for recognition } \\
\text { by macrophages via the mannose } \\
\text { receptor. In AIDS patients can } \\
\text { be a major problem. Indefinite } \\
\text { treatment often the mode. }\end{array}$ \\
\hline $\begin{array}{l}\text { Derrnatophytosis tinea barbae } \\
\text { and tinea capitis (ringworm). This } \\
\text { and the following three diseases } \\
\text { in the } 22^{\text {th }} \text { edition are tabulated } \\
\text { together as relatively minor fungal } \\
\text { diseases of skin hair and nails. }\end{array}$ & $\begin{array}{l}\text { Various spp of } \\
\text { microsporum and } \\
\text { TrichophytonSkin }\end{array}$ & $\begin{array}{l}\text { Endemic in urban } \\
\text { areas in Eastern USA, } \\
\text { Puerto Rico and } \\
\text { Australia }\end{array}$ & $\begin{array}{l}\text { B35.0 } \\
\text { Slight }\end{array}$ & All ages susceptible & $\begin{array}{l}\text { Children below the age of } \\
\text { puberty are particularly } \\
\text { susceptible }\end{array}$ & $\begin{array}{l}\text { Reinfections not } \\
\text { recordedImmunity NK }\end{array}$ & $\begin{array}{l}\text { Humans and a variety } \\
\text { of animal spp. }\end{array}$ & $\begin{array}{l}\text { Treatment can in time give } \\
\text { complete recovery }\end{array}$ \\
\hline
\end{tabular}

Infect Dis Ther, Volume 1(2): 27-48, 2020 


\begin{tabular}{|c|c|c|c|c|c|c|c|c|}
\hline Disease & \begin{tabular}{|l}
$\begin{array}{l}\text { Infectious agent. } \\
\text { Target organ if any. }\end{array}$ \\
\end{tabular} & Location & $\begin{array}{l}\text { ICD 10entry. } \\
\text { Impact }\end{array}$ & Susceptibility & Special risk factors & Immunity & $\begin{array}{l}\text { Primary reservoir } \\
\text { and Vectors }\end{array}$ & Comments, treatable? \\
\hline $\begin{array}{l}\text { Dermatophytosis, tinea cruris and } \\
\text { tinea corporis (groin and body } \\
\text { ringworm) }\end{array}$ & $\begin{array}{l}\text { As above with a few other } \\
\text { possible spp. } \\
\text { Skin }\end{array}$ & worldwide & \begin{tabular}{|l} 
B35.6 \\
Inconvenient
\end{tabular} & $\begin{array}{l}\text { Widespread, all ages affected, hot } \\
\text { groins a starting point }\end{array}$ & $\begin{array}{l}\text { Males more frequently affected } \\
\text { than females }\end{array}$ & None recorded & $\begin{array}{l}\text { Soil and humans. } \\
\text { The groin infection } \\
\text { is almost exclusively } \\
\text { male. }\end{array}$ & СТХ \\
\hline $\begin{array}{l}\text { Dermatophytosis, tinea pedis, } \\
\text { Athletes foot }\end{array}$ & $\begin{array}{l}\text { Trichophyton rubrum and } \\
\text { others } \\
\text { Foot skin }\end{array}$ & Worldwide & $\begin{array}{l}\text { B35.3 } \\
\text { Inconvenient }\end{array}$ & Variable, infection may be inapparent & $\begin{array}{l}\text { Males more affected than } \\
\text { females. }\end{array}$ & Repeated attacks are frequent & Humans & CTX initially by local fungicides \\
\hline $\begin{array}{l}\text { Onchomycosis, Tinea unguium } \\
\text { (ringworm of the nails) }\end{array}$ & \begin{tabular}{|l|} 
Various \\
Trichophyton spp. \\
Nails usually of the feet \\
\end{tabular} & Common & \begin{tabular}{|l} 
B35.1 \\
Inconvenient
\end{tabular} & Variable & ? & Repeated attacks frequent & $\begin{array}{l}\text { Humansmore rarely } \\
\text { soil }\end{array}$ & CTX over long periods \\
\hline Disease & $\begin{array}{l}\text { Infectious agent. } \\
\text { Target organ if any. }\end{array}$ & Location & $\begin{array}{l}\text { ICD } 10 \text { entry. } \\
\text { Impact }\end{array}$ & Susceptibility & Special risk factors & Immunity & $\begin{array}{l}\text { Primary reservoir } \\
\text { and Vectors }\end{array}$ & Comments, treatable? \\
\hline $\begin{array}{l}\text { Histoplasmosis (two diseases here } \\
\text { of which only the more common } \\
\text { is considered), number of causal } \\
\text { agents but no common names } \\
\text { given }\end{array}$ & $\begin{array}{l}\text { Histoplasma capsulatum } \\
\text { can be a respiratory } \\
\text { disease but can also } \\
\text { present in a disseminated } \\
\text { form. } \\
\text { Lungs }\end{array}$ & \begin{tabular}{|l|} 
Common in particular \\
foci, rare in Europe. In \\
some parts of central \\
and Eastern USA $80 \%$ \\
of the population are \\
histoplasmin sensitive \\
indicative of contact \\
with the organism. \\
\end{tabular} & $\begin{array}{l}\text { B39.5 } \\
\text { Of varying severity. Can be } \\
\text { lethal }\end{array}$ & $\begin{array}{l}\text { Infection is common but overt clinical } \\
\text { disease is not. }\end{array}$ & $\begin{array}{l}\text { Possibly opportunistic in } \\
\text { immunosuppressed individuals }\end{array}$ & $\begin{array}{l}\text { In apparent infections that } \\
\text { are common seem to give } \\
\text { increased resistance to } \\
\text { (further?)infection }\end{array}$ & $\begin{array}{l}\text { Soil with undisturbed } \\
\text { bird or bat droppings }\end{array}$ & $\begin{array}{l}\text { CTX, more difficult in } \\
\text { immunosuppressed individuals. }\end{array}$ \\
\hline $\begin{array}{l}\text { Eumycotic Mycetoma Devil's } \\
\text { grippe, Bornholm Disease. See } \\
\text { alsonocardiosis in bacterial } \\
\text { diseases }\end{array}$ & $\begin{array}{l}\text { Madurellamycematoma- } \\
\text { tisplus others and a set of } \\
\text { bacteria that give compa- } \\
\text { rable lesions. } \\
\text { skin }\end{array}$ & $\begin{array}{l}\text { Rare in continental } \\
\text { USA but common in } \\
\text { Mexico }\end{array}$ & $\begin{array}{l}\text { B47.0 } \\
\text { Nasty }\end{array}$ & $\begin{array}{l}\text { Causal organism's common but } \\
\text { disease is relatively rare. Implication } \\
\text { is that resistance is usual. }\end{array}$ & $\begin{array}{l}\text { Barefoot workers, ie infection is } \\
\text { secondary to wounding. }\end{array}$ & None recorded & Soil & $\begin{array}{l}\text { CTX and or surgery in extreme } \\
\text { cases. }\end{array}$ \\
\hline Disease & \begin{tabular}{|l|} 
Infectious agent. \\
Target organ if any.
\end{tabular} & Location & $\begin{array}{l}\text { ICD } 10 \text { entry. } \\
\text { Impact }\end{array}$ & Susceptibility & Special risk factors & Immunity & $\begin{array}{l}\text { Primary reservoir } \\
\text { and Vectors }\end{array}$ & Comments, treatable? \\
\hline $\begin{array}{l}\text { Paracoccidiomycosis, South } \\
\text { American blastomycosis. }\end{array}$ & \begin{tabular}{|l} 
Paracoccidioides \\
braziliensis \\
Lungs siteof primary \\
infection
\end{tabular} & \begin{tabular}{|l|} 
Endemic in tropical \\
and subtropical regions \\
of S. America and to a \\
lesser extent in Central \\
America \\
\end{tabular} & $\begin{array}{l}\text { B41 } \\
\text { A serious and sometimes fatal } \\
\text { disease }\end{array}$ & Unknown & ? & ? & $\begin{array}{l}\text { Presumably soil or } \\
\text { fungus laden dust }\end{array}$ & СТХ \\
\hline Sporotrichosis, & $\begin{array}{l}\text { Sporothrixschenckii } \\
\text { Skin. }\end{array}$ & All parts of the world & \begin{tabular}{|l} 
B42 \\
An occupational disease of \\
gardeners and horticulturists. \\
Fatalities uncommon
\end{tabular} & unknown & ? & ? & Soil & СТХ \\
\hline $\begin{array}{l}\text { Mucormycosis. Zygomycosis, } \\
\text { A complex of diseases with a } \\
\text { number of causal organisms. }\end{array}$ & $\begin{array}{l}\text { Various zygomycete } \\
\text { fungi including Rhizopus } \\
\text { arrbizus }\end{array}$ & \begin{tabular}{|l|} 
Worldwide, incidence \\
may be increasing \\
because of longer \\
survival of various \\
kinds of patient such \\
as those with diabetes \\
mellitus, and certain \\
blood dyscrasias
\end{tabular} & $\begin{array}{l}\text { B46.0 } \\
\text { Extraordinary disease that in } \\
\text { susceptible patients causes nasty } \\
\text { facial problems with erosion of } \\
\text { many nasal structures. In the } \\
\text { lung it can cause blood clotting } \\
\text { and lung infarcts. }\end{array}$ & $\begin{array}{l}\text { The argument put forward is that } \\
\text { as the disease is rare but the fungi } \\
\text { concerned are common there must be } \\
\text { resistance to the disease. }\end{array}$ & $\begin{array}{l}\text { A variety of debilitating } \\
\text { conditions predispose to the } \\
\text { disease. What is not stated is } \\
\text { whether it ever occurs in normal } \\
\text { individuals. It is certainly rare. }\end{array}$ & $\begin{array}{l}\text { Difficult to say. If } \\
\text { immunosuppression } \\
\text { predisposes to the disease it } \\
\text { could be correctly supposed } \\
\text { that the immune response } \\
\text { is the basis of the resistance } \\
\text { in non-immunosuppressed } \\
\text { individuals. This is not the only } \\
\text { possible explanation however. }\end{array}$ & Common saprophytes. & CTX and/or surgery. \\
\hline
\end{tabular}


Table 5: Flat Worms, Trematodes, Including Tapeworms, Non-Segmented.

\begin{tabular}{|c|c|c|c|c|c|c|c|c|}
\hline Disease & \begin{tabular}{|l|} 
Infectious agent. \\
Target organ if any.
\end{tabular} & Location & $\begin{array}{l}\text { ICD 10entry. } \\
\text { Impact }\end{array}$ & Susceptibility & Special risk factors & Immunity & $\begin{array}{l}\text { Primary reservoir and } \\
\text { vectors }\end{array}$ & \begin{tabular}{|l|}
$\begin{array}{l}\text { Comments, including } \\
\text { treatment }\end{array}$ \\
\end{tabular} \\
\hline $\begin{array}{l}\text { Liver fluke disease } \\
\text { Clonorchiasis, } \\
\text { Opisthorchiasis }\end{array}$ & $\begin{array}{l}\text { Clonorchis sinensis, Opisthorchis } \\
\text { felinensisandviverrini. } \\
\text { Diseases of the bile ducts, } \\
\text { Cholangiocarcinoma can be a } \\
\text { late side effect of infection with } \\
\text { O. verrini. }\end{array}$ & \begin{tabular}{|l} 
Endemic in South East \\
China and other parts of SE \\
Asia. Opisthorchiasis is also \\
frequent in the old states of \\
the USSR. It is estimated that \\
globally some $700 \mathrm{~m}$ people \\
are at risk of infection. \\
\end{tabular} & $\begin{array}{l}\text { B66.1, B66.0 (C22.1, } \\
\text { cholangiocarcinoma)Often } \\
\text { completely asymptomatic. Very } \\
\text { slow chronic diseases often lasting } \\
\text { for } 30 \text { or more years only rarely } \\
\text { a cause of death but a major risk } \\
\text { factor for cholangiocarcinoma }\end{array}$ & Universal & $\begin{array}{l}\text { In endemic areas highest } \\
\text { prevalence in adults over age } \\
\text { of } 30\end{array}$ & $\begin{array}{l}\text { None cited but fact } \\
\text { that infection is often } \\
\text { and probably usually } \\
\text { asymptomatic is interesting }\end{array}$ & $\begin{array}{l}\text { Humans, cats, dogs, } \\
\text { swine, rats and other } \\
\text { animals }\end{array}$ & $\begin{array}{l}\text { A danger from raw or } \\
\text { undercooked freshwater } \\
\text { fish. Treatable with CTX. } \\
\text { No person to person } \\
\text { transmission }\end{array}$ \\
\hline \begin{tabular}{|l|} 
Tapeworms, in the $20^{\text {th }}$ \\
edition of the manual, \\
following the ICD listing, \\
considerssomenine \\
different tapeworm \\
infections. Here only three \\
of the most common will \\
be considered
\end{tabular} & $\begin{array}{l}\text { Hymenolepis nana. } \\
\text { Dwarf tapeworm } \\
\text { Intestinal infection, }\end{array}$ & Cosmopolitan & $\begin{array}{l}\text { B71.0 } \\
\text { Rarer in colder climates }\end{array}$ & Universal & $\begin{array}{l}\text { Children more } \\
\text { susceptible than adults, } \\
\text { immunosuppressed or } \\
\text { malnourished people at } \\
\text { particular risk }\end{array}$ & $\begin{array}{l}\text { Infection leads to resistance } \\
\text { to (?further) infection }\end{array}$ & $\begin{array}{l}\text { Humans and possibly } \\
\text { mice (in which it grows } \\
\text { well under experimental } \\
\text { circumstances) }\end{array}$ & $\begin{array}{l}\text { A very small addition to } \\
\text { man!, autoinfection occurs. } \\
\text { CTX effective. }\end{array}$ \\
\hline Disease & \begin{tabular}{|l|} 
Infectious agent. \\
Target organ if any.
\end{tabular} & Location & $\begin{array}{l}\text { ICD } 10 \text { entry. } \\
\text { Impact }\end{array}$ & Susceptibility & Special risk factors & Immunity & $\begin{array}{l}\text { Primary reservoir and } \\
\text { Vectors }\end{array}$ & Comments, treatable? \\
\hline $\begin{array}{l}\text { Diphyllothriasis, Broad or } \\
\text { fish tapeworm infection }\end{array}$ & \begin{tabular}{|l|} 
Diphyllobothrium latum and \\
several other spp. of the genus. \\
Intestinal infection of long \\
duration symptoms commonly \\
trivial.
\end{tabular} & $\begin{array}{l}\text { Lake regions in } \mathrm{N} \\
\text { Hemisphere and subarctic } \\
\text { regions where eating raw fish } \\
\text { is practised }\end{array}$ & B70.0slight & Universal & None given & $\begin{array}{l}\text { Reinfection can occur thus } \\
\text { immune resistance does not } \\
\text { apparently develop }\end{array}$ & $\begin{array}{l}\text { Humans and a variety of } \\
\text { animals including polar } \\
\text { bears }\end{array}$ & $\begin{array}{l}\text { Another raw fish problem } \\
\text { CTX will work. }\end{array}$ \\
\hline $\begin{array}{l}\text { Taeniasis (pork and } \\
\text { beef tapeworm) and } \\
\text { Cysticercosis }\end{array}$ & \begin{tabular}{|l|} 
Taenia solium, porkand $T$ \\
saginata beef. Initially intestinal \\
infections but development \\
and dissemination of cysticerci \\
can create massive later \\
complications \\
\end{tabular} & $\begin{array}{l}\text { Worldwide wherever } \\
\text { pork and beef are eaten } \\
\text { insufficiently cooked and } \\
\text { sanitary conditions allow } \\
\text { cattle access to human faeces }\end{array}$ & $\begin{array}{l}\text { B68 } \\
\text { Consequences of infection grave if } \\
\text { cysticercosis arises }\end{array}$ & General & $\begin{array}{l}\text { Those living in poor and } \\
\text { insanitary circumstances. }\end{array}$ & $\begin{array}{l}\text { No immunity reported } \\
\text { though more than one } \\
\text { tapeworm per host is rare }\end{array}$ & $\begin{array}{l}\text { Pigs for T.soliumand } \\
\text { cattle for T.saginataare } \\
\text { the intermediate hosts. } \\
\text { Humans are the definitive } \\
\text { hosts }\end{array}$ & $\begin{array}{l}\text { CTX or surgery. Treatment } \\
\text { complicated by consequences } \\
\text { of killing cysticerci. }\end{array}$ \\
\hline \begin{tabular}{|l|} 
Echinococcosis, cystic \\
hydatid disease.Three \\
grades or the disease are \\
recognized, cystic, alveolar \\
and polycystic, here \\
only cystic form will be \\
considered. \\
\end{tabular} & \begin{tabular}{|l|} 
Echinococcus granulosus \\
Slowly developing disease \\
commonly in liver or lungs but \\
can be found elsewhere
\end{tabular} & $\begin{array}{l}\text { All continents except } \\
\text { antarctica }\end{array}$ & $\begin{array}{l}\text { B67.0 } \\
\text { Not stated although note relatively } \\
\text { high grading. }\end{array}$ & \begin{tabular}{|l} 
None given \\
presumably universal
\end{tabular} & $\begin{array}{l}\text { Children more likely to be } \\
\text { infected but they are also } \\
\text { more likely to play with dogs. } \\
\text { Really no evidence of greater } \\
\text { susceptibility in children }\end{array}$ & None written of & $\begin{array}{l}\text { Dogs and a variety of } \\
\text { other animals }\end{array}$ & $\begin{array}{l}\text { Even multiply infected } \\
\text { animals are often totally } \\
\text { asymptomatic! Problems } \\
\text { arise largely because of } \\
\text { hydatid cysts Either surgical } \\
\text { treatment of cysts or CTX } \\
\text { can work } \\
\end{array}$ \\
\hline Disease & \begin{tabular}{|l|} 
Infectious agent. \\
Target organ if any.
\end{tabular} & Location & $\begin{array}{l}\text { ICD } 10 \text { entry. } \\
\text { Impact }\end{array}$ & Susceptibility & Special risk factors & Immunity & \begin{tabular}{|l|} 
Primary reservoir and \\
Vectors
\end{tabular} & Comments, treatable? \\
\hline $\begin{array}{l}\text { Fascioliasis, a zoonotic } \\
\text { liver fluke }\end{array}$ & $\begin{array}{l}\text { Fasciola hepatica and to a lesser } \\
\text { extent } F \text { Figantica (sheep liver } \\
\text { fluke) }\end{array}$ & $\begin{array}{l}\text { Reported in various cattle } \\
\text { rearing areas in all continents } \\
\text { except antarctica }\end{array}$ & $\begin{array}{l}\text { B66.3 } \\
\text { Accidental in man }\end{array}$ & $\begin{array}{l}\text { All ages susceptible, } \\
\text { infection persists } \\
\text { indefinitely }\end{array}$ & None given & None written of & Sheep cattle and snails & $\begin{array}{l}\text { Transfer to man commonly } \\
\text { by consumption of aquatic } \\
\text { plants with attached } \\
\text { metacercariae. Nasty disease } \\
\text { in that there is no sure fire } \\
\text { cure! }\end{array}$ \\
\hline
\end{tabular}




\begin{tabular}{|c|c|c|c|c|c|c|c|c|}
\hline $\begin{array}{l}\text { Fasciolopsiasis, no } \\
\text { synonyms }\end{array}$ & $\begin{array}{l}\text { Fasciolopsisbuski(a large liver } \\
\text { fluke up to } 7 \mathrm{~cm} \text { in length) }\end{array}$ & Rural Southeast Asia & $\begin{array}{l}\text { B66.5 } \\
\text { Light infections commonly } \\
\text { asymptomatic }\end{array}$ & Universal & $\begin{array}{l}\text { In malnourished individuals } \\
\text { effects of infection can be } \\
\text { more pronounced. Severity } \\
\text { of disease determined by } \\
\text { number of worms }\end{array}$ & None indicated & Swine and humans & $\begin{array}{l}\text { Another aquatic plant with } \\
\text { snail problem especially in } \\
\text { the vicinity of pig faeces. } \\
\text { CTX. }\end{array}$ \\
\hline Disease & $\begin{array}{l}\text { Infectious agent. } \\
\text { Target organ if any. }\end{array}$ & Location & $\begin{array}{l}\text { ICD } 10 \text { entry. } \\
\text { Impact }\end{array}$ & Susceptibility & Special risk factors & Immunity & \begin{tabular}{|l} 
Primary reservoir and \\
Vectors
\end{tabular} & Comments, treatable? \\
\hline $\begin{array}{l}\text { Paragonimiasis, lung fluke } \\
\text { disease }\end{array}$ & $\begin{array}{l}\text { Paragonimuswestermani } \\
\text { And other spp.of the genus } \\
\text { Lungs and elsewhere }\end{array}$ & $\begin{array}{l}\text { Reported from various places } \\
\text { particularly far East }\end{array}$ & $\begin{array}{l}\text { B66.4 } \\
\text { Said to be } 22.3 \text { million people } \\
\text { infected in China }\end{array}$ & General & $\begin{array}{l}\text { Infectionmay last for years } \\
\text { and the infected person would } \\
\text { seem well }\end{array}$ & None indicated & $\begin{array}{l}\text { Humans and various } \\
\text { domestic animals, fish } \\
\text { become associated with } \\
\text { the faeces orsputum that } \\
\text { has been spat out }\end{array}$ & $\begin{array}{l}\text { Another uncooked fish } \\
\text { disease in which the lung } \\
\text { is affected. Often found in } \\
\text { snails and edible crustacea. } \\
\text { The larvae can even survive } \\
\text { pickling! CTX indicated as } \\
\text { successful }\end{array}$ \\
\hline $\begin{array}{l}\text { Schistosomiasis(bilhar- } \\
\text { ziasis) }\end{array}$ & $\begin{array}{l}\text { Schistosoma mansoniiand } \\
\text { others } \\
\text { A blood fluke. }\end{array}$ & $\begin{array}{l}\text { Various tropical countries, } \\
\text { Africa, China and so on. Not } \\
\text { indigenous to N America }\end{array}$ & $\begin{array}{l}\text { B65 } \\
\text { Primary disease is insignificant the } \\
\text { consequences of chronic infection } \\
\text { can be serious }\end{array}$ & General & $\begin{array}{l}\text { None given except of course } \\
\text { forthose who bath in infected } \\
\text { waters }\end{array}$ & $\begin{array}{l}\text { Any immunity is variable } \\
\text { and poorly defined }\end{array}$ & $\begin{array}{l}\text { Humans and all sorts of } \\
\text { other animals. 'Vector' } \\
\text { often snails. }\end{array}$ & $\begin{array}{l}\text { CTX treatable. No } \\
\text { direct person to person } \\
\text { transmission but indirect } \\
\text { contamination can occur } \\
\text { via eggs discharged in faeces } \\
\text { into water. A major hazard of } \\
\text { swimming in tropical fresh } \\
\text { water }\end{array}$ \\
\hline
\end{tabular}

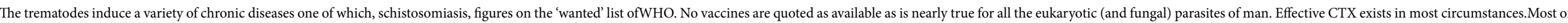

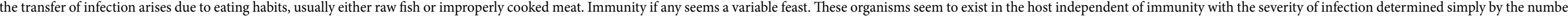

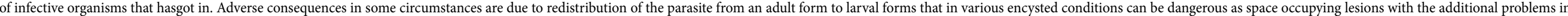
some instances of eventual disruption with liberation of a variety of pharmacologically active substances. 
Table 6: Nematodes (Non-Segmented Round Worms)

\begin{tabular}{|c|c|c|c|c|c|c|c|c|}
\hline Disease & Infectious agent.Target organ if any. & Location & $\begin{array}{l}\text { ICD } 10 \text { entry. } \\
\text { Impact }\end{array}$ & Susceptibility & Special risk factors & Immunity & $\begin{array}{l}\text { Primary reservoir and } \\
\text { vectors }\end{array}$ & Comments, treatment? \\
\hline $\begin{array}{l}\text { Anisakiasis, no } \\
\text { synonyms quoted }\end{array}$ & $\begin{array}{l}\text { Anisakis and Pseudoterranova, larvae } \\
\text { Gastro intestinal mucosa. }\end{array}$ & $\begin{array}{l}\text { Where 'uncooked' fish } \\
\text { is eaten } \\
\text { Most cases recorded in } \\
\text { Japan, } \\
\end{array}$ & $\begin{array}{l}\text { B81.0 } \\
\text { slight }\end{array}$ & universal & NK & NK & $\begin{array}{l}\text { Marine mammals various } \\
\text { intermediate hosts such } \\
\text { as small crustaceans and a } \\
\text { variety of fish }\end{array}$ & $\begin{array}{l}\text { On the increase, as eating of raw } \\
\text { fish increases in the Western world. } \\
\text { Surgical removal is all that is quoted } \\
\text { by way of treatment }\end{array}$ \\
\hline $\begin{array}{l}\text { Ascariasis, roundworm } \\
\text { infection }\end{array}$ & $\begin{array}{l}\text { Ascaris lumbricoides } \\
\text { Intestine but can give rise to symptoms } \\
\text { I many parts of the body. }\end{array}$ & Moist tropical countries & $\begin{array}{l}\text { B77Common and } \\
\text { worldwide, in many } \\
\text { countries prevalence } 50 \% ! \\
\text { complications of chronic } \\
\text { infection can be severe, } \\
\end{array}$ & General & $\begin{array}{l}\text { Young children, 3-8 years } \\
\text { in whom prevalence and } \\
\text { intensity of infection is } \\
\text { highest. }\end{array}$ & NK & $\begin{array}{l}\text { Humans, often as a } \\
\text { consequence of defaecation } \\
\text { in soil. Ascarid eggs in soil } \\
\text { can be viable for many years. }\end{array}$ & CTX that can be complicated. \\
\hline $\begin{array}{l}\text { Capillariasis, intestinal } \\
\text { capillariasis }\end{array}$ & $\begin{array}{l}\text { CapillariaphillipinensisVariable } \\
\text { intestines, liver and respiratory tract }\end{array}$ & $\begin{array}{l}\text { Far East particularly } \\
\text { Phillipines and Japan } \\
\text { where it is endemic }\end{array}$ & $\begin{array}{l}\text { B81.1Sporadic. On Luzon } \\
\text { some } 1800 \text { cases have been } \\
\text { recorded. Case fatality rates } \\
\text { of } 10 \% \text { have been recorded. }\end{array}$ & General & $\begin{array}{l}\text { Perhaps males between the } \\
\text { ages of } 20 \text { and } 45 \text { but this } \\
\text { could be an occupational } \\
\text { issue. }\end{array}$ & ? & $\begin{array}{l}\text { Unknown, perhaps aquatic } \\
\text { birds fish are intermediate } \\
\text { hosts it is believed. }\end{array}$ & $\begin{array}{l}\text { Associated with eating poorly } \\
\text { cooked fish, CTX available }\end{array}$ \\
\hline Hepatic capillariasis & Capillaria hepatica & $\begin{array}{l}\text { Rare only recognized } \\
\text { as a human disease in } \\
\text { 1924. Worldwide but } \\
\text { not common. }\end{array}$ & $\mid \begin{array}{l}\text { B83.8 } \\
\text { Occasionally fatal }\end{array}$ & General & $\begin{array}{l}\text { Malnourished children are } \\
\text { particularly at risk, } 3 \text { years of } \\
\text { age in particular. }\end{array}$ & ? & $\begin{array}{l}\text { Rats but a wide variety of } \\
\text { domestic and other animals. }\end{array}$ & $\begin{array}{l}\text { A liver disease about which because } \\
\text { of its rarity little seems to be known. } \\
\text { CTX effective. }\end{array}$ \\
\hline \begin{tabular}{|l} 
Capillariasis, \\
Pulmonary capillariasis
\end{tabular} & $\begin{array}{l}\text { C.aerophila } \\
\text { Larvae from the intestine migrate to } \\
\text { the lungs. }\end{array}$ & $\begin{array}{l}\text { Worldwide but rare. Too } \\
\text { few cases so far for any } \\
\text { sensible generalistions. } \\
\end{array}$ & B83.8 & General & Children & ? & $\begin{array}{l}\text { Cats, dogs and other } \\
\text { carnivorous mammals. }\end{array}$ & $\begin{array}{l}\text { Mebendazole, albendazole and } \\
\text { thisbendazole. }\end{array}$ \\
\hline $\begin{array}{l}\text { Dranunculiasis, Guinea } \\
\text { worm infection }\end{array}$ & $\begin{array}{l}\text { Dranunculus medinensis } \\
\text { Subcutaneous or deeper tissues..often } \\
\text { initially on a foot. }\end{array}$ & $\begin{array}{l}\text { Africa and in Asia, } \\
\text { particularly in countries } \\
\text { with dry climates }\end{array}$ & \begin{tabular}{|l} 
B72 \\
Prognosis generally good \\
unless secondary bacterial \\
infection occurs \\
\end{tabular} & Universal & $\begin{array}{l}\text { In some locales all people are } \\
\text { infected, mainly young adults } \\
\text { in other areas far fewer carry } \\
\text { the organism. }\end{array}$ & $\begin{array}{l}\text { None recorded, multiple } \\
\text { infections occur in the } \\
\text { same person }\end{array}$ & Humans & $\begin{array}{l}\text { WHO agreed to abolish the disease } \\
\text { in } 1991 \text { but they have not yet } \\
\text { succeeded. CTX not always effective } \\
\text { often difficult. }\end{array}$ \\
\hline Disease & Infectious agent.Target organ if any. & Location & $\begin{array}{l}\text { ICD } 10 \text { entry. } \\
\text { Impact }\end{array}$ & Susceptibility & Special risk factors & Immunity & $\begin{array}{l}\text { Primary reservoir and } \\
\text { vectors }\end{array}$ & Comments, treatment? \\
\hline $\begin{array}{l}\text { Enterobiasis, } \\
\text { (pinworms) }\end{array}$ & $\begin{array}{l}\text { Enterobius vermicularis } \\
\text { Intestine. }\end{array}$ & Worldwide & $\begin{array}{l}\text { B80 } \\
\text { Irritant but rarely with } \\
\text { serious consequences }\end{array}$ & Universal & $\begin{array}{l}\text { Differences in severity of } \\
\text { infection are due to different } \\
\text { levels of exposure. Ranges } \\
\text { from asymptomatic to } \\
\text { recurrently symptomatic. }\end{array}$ & None recorded & $\begin{array}{l}\text { Humans, none of the animal } \\
\text { pinworms communicate } \\
\text { to man }\end{array}$ & $\begin{array}{l}\text { One of the most common parasites } \\
\text { of school children. Parents } \\
\text { occasionally infected and infections } \\
\text { in domiciliary institutions can } \\
\text { be common. The only nematode } \\
\text { disease that shows person to person } \\
\text { transmission. Easily treated. }\end{array}$ \\
\hline $\begin{array}{l}\text { Filariasis, a variety of } \\
\text { local or eponymous } \\
\text { namings, eg } \\
\text { Bancroftian filariasis, } \\
\text { Malayan filariasis, } \\
\text { Timoreanfilarisis }\end{array}$ & $\begin{array}{l}\text { Wucheriabancrofti, Brugiamalayi and } \\
\text { Brugiatimori. } \\
\text { All infections of lymphatics }\end{array}$ & $\begin{array}{l}\text { Variously distributed, } \\
\text { bancofti wide } \\
\text { spreadparticularly in } \\
\text { warm humid regions } \\
\text { the other two more } \\
\text { restricted }\end{array}$ & \begin{tabular}{|l} 
B74.0, B74.1, B74.2 \\
Repeated infections in \\
endemic regions can lead to \\
elephantiasis
\end{tabular} & Universal & $\begin{array}{l}\text { ?very long persistent } \\
\text { condition }\end{array}$ & $\begin{array}{l}\text { None recorded } \\
\text { Repeated infections occur }\end{array}$ & $\begin{array}{l}\text { Humans with microfilariae. } \\
\text { Mosquitos are the vector }\end{array}$ & $\begin{array}{l}\text { Not easy successfully to treat. Drugs } \\
\text { are available and have been used on } \\
\text { a mass basis but side effects can be } \\
\text { bad. Watch this space. }\end{array}$ \\
\hline
\end{tabular}




\begin{tabular}{|c|c|c|c|c|c|c|c|c|}
\hline Disease & Infectious agent. Target organ if any. & Location & $\begin{array}{l}\text { ICD } 10 \text { entry. } \\
\text { Impact }\end{array}$ & Susceptibility & Special risk factors & Immunity & $\begin{array}{l}\text { Primary reservoir and } \\
\text { vectors }\end{array}$ & Comments, treatment? \\
\hline $\begin{array}{l}\text { Hookworm disease, } \\
\text { ancylostimiasis, } \\
\text { uncinariasis, } \\
\text { necatoriasis. }\end{array}$ & $\begin{array}{l}\text { Ancylostoma duodenale, A. ceylanicum, } \\
\text { A. braziliensis, A caninum and } \\
\text { Necator americanus } \\
\text { Intestine. }\end{array}$ & $\begin{array}{l}\text { Widely endemic in } \\
\text { tropical and subtropical } \\
\text { regions }\end{array}$ & \begin{tabular}{|l} 
B76 \\
Variable light infections are \\
often asymptomatic
\end{tabular} & Universal & None given & $\begin{array}{l}\text { No evidence that } \\
\text { immunity develops with } \\
\text { infection }\end{array}$ & $\begin{array}{l}\text { Humans for one two sppin } \\
\text { cats and dogs for two others }\end{array}$ & $\begin{array}{l}\text { Big disease in cattle but no } \\
\text { indication that there is any transfer } \\
\text { to man. Note also in cattle that an } \\
\text { irradiated vaccine was successfully } \\
\text { developed, perhaps it was a different } \\
\text { kind of hookworm. CTx will usually } \\
\text { work. }\end{array}$ \\
\hline $\begin{array}{l}\text { Loiasis, Loa loa } \\
\text { infection, Eye worm } \\
\text { disease of Africa, } \\
\text { Calabar swelling } \\
\end{array}$ & $\begin{array}{l}\text { Loa loaAny body part but } \\
\text { Particularly nasty in the eye. }\end{array}$ & $\begin{array}{l}\text { Widely distributed in } \\
\text { the African rain forest }\end{array}$ & \begin{tabular}{|l|} 
B74.3 In some parts of \\
central Africa ninety per \\
cent of the population are \\
infected
\end{tabular} & Universal & Chronic disease & None apparent & Humans, deer fly vector & $\begin{array}{l}\text { Treatment often complicated by } \\
\text { hypersensitivity effects. Difficult in } \\
\text { many ways. }\end{array}$ \\
\hline Disease & Infectious agent.Target organ if any. & Location & \begin{tabular}{|l|} 
ICD 10 entry. \\
Impact
\end{tabular} & Susceptibility & Special risk factors & Immunity & \begin{tabular}{|l}
$\begin{array}{l}\text { Primary reservoir and } \\
\text { vectors }\end{array}$ \\
\end{tabular} & Comments, treatment? \\
\hline $\begin{array}{l}\text { Onchercerciasis, river } \\
\text { blindness }\end{array}$ & $\begin{array}{l}\text { Onchocerca volvulus } \\
\text { Skin and eye. }\end{array}$ & \begin{tabular}{|l|} 
Restricted distribution \\
in various tropical \\
regions but $97 \%$ of cases \\
in sub-saharanAfrica/
\end{tabular} & \begin{tabular}{|l|} 
B73 \\
Situation now very different \\
in that the Onchocerciasis \\
control program in W Africa \\
has proved effective but \\
previously a major disease \\
causingblindness among \\
many other unpleasant \\
symptoms
\end{tabular} & Universal & None given & Reinfection can occur & $\begin{array}{l}\text { Humans, transmitted by } \\
\text { infected black flies of the } \\
\text { genus simulium }\end{array}$ & $\begin{array}{l}\text { Has been a major disease but the } \\
\text { use of ivermectin as a larvicide } \\
\text { in patients and black fly control } \\
\text { measures are achieving good control } \\
\text { it seems. Surgery sometimes used as } \\
\text { an adjunct treatment. }\end{array}$ \\
\hline Strongyloidiasis & $\begin{array}{l}\text { Strongyloidesstercoralisandfulleborni } \\
\text { Skin. And elsewhere. }\end{array}$ & $\begin{array}{l}\text { Throughout tropical } \\
\text { and temperate areas } \\
\text { more usual in areas of } \\
\text { high humidity } \\
\end{array}$ & $\begin{array}{l}\text { B78 } \\
\text { Often asymptomatic }\end{array}$ & Universal & Immunosuppressed patients & $\begin{array}{l}\text { Acquired immunity has } \\
\text { been demonstrated in } \\
\text { experimental animals but } \\
\text { not in man. }\end{array}$ & Humans mainly & $\begin{array}{l}\text { Ivermectin, often repeated will be } \\
\text { effective. }\end{array}$ \\
\hline $\begin{array}{l}\text { Creeping eruption } \\
\text { Cutaneous larva } \\
\text { migrans. }\end{array}$ & $\begin{array}{l}\text { A. } \quad \text { caninum. A } \\
\text { braziliensisDermatitis, } \\
\text { commonly feet and } \\
\text { buttocks. }\end{array}$ & $\begin{array}{l}\text { Most tropical and sub- } \\
\text { tropical countries world } \\
\text { wide }\end{array}$ & B876.0,B876.9 & ? & $\begin{array}{l}\text { Those who regularly come } \\
\text { into contact with soil. } \\
\text { Contaminated with dog or } \\
\text { cat faeces. }\end{array}$ & $\begin{array}{l}\text { Commonly self limiting } \\
\text { but no indication given } \\
\text { of how. }\end{array}$ & Dogs and cats & Freezing infected areas \\
\hline Disease & Infectious agent.Target organ if any. & Location & $\begin{array}{l}\text { ICD } 10 \text { entry. } \\
\text { Impact }\end{array}$ & Susceptibility & Special risk factors & Immunity & $\begin{array}{l}\text { Primary reservoir and } \\
\text { vectors }\end{array}$ & Comments, treatment? \\
\hline $\begin{array}{l}\text { Toxocariasis, visceral } \\
\text { larva migrans }\end{array}$ & $\begin{array}{l}\text { ToxocaracansiandT.cati } \\
\text { Eosinophilia a common manifestation } \\
\text { of diseasecan affect ceyes. }\end{array}$ & Worldwide & \begin{tabular}{|l} 
B83.0 \\
Usually relatively mild, \\
chronic rarely fatal. In \\
some parts of the world the \\
majority of children are \\
infected
\end{tabular} & $\begin{array}{l}\text { Lower incidence in } \\
\text { older people largely } \\
\text { because of lower } \\
\text { exposure }\end{array}$ & $\begin{array}{l}\text { Can be severe in children } \\
\text { 4-14 months }\end{array}$ & $\begin{array}{l}\text { Reinfection can occur. } \\
\text { Viable larvae can stay } \\
\text { asymptomatically in } \\
\text { tissues for many years }\end{array}$ & $\begin{array}{l}\text { Dogs and cats but infection } \\
\text { often by ingestion of eggs } \\
\text { from contaminated soil }\end{array}$ & $\begin{array}{l}\text { A latent infection ina female } \\
\text { dog can result in reactivation of } \\
\text { infection and its passage to the pups } \\
\text { through the milk. CTX but as the } \\
\text { text remarks effectiveness of anti- } \\
\text { helminthics is questionable at best! }\end{array}$ \\
\hline $\begin{array}{l}\text { Trichinellosis, } \\
\text { trichiniasis, trichinosis }\end{array}$ & $\begin{array}{l}\text { Trichinella spiralis } \\
\text { And other spp. of the genus }\end{array}$ & $\begin{array}{l}\text { Worldwide but very } \\
\text { variable in incidence }\end{array}$ & $\begin{array}{l}\text { B75Varies from inapparent } \\
\text { infection to fulminating fatal } \\
\text { disease depending on level } \\
\text { of intake. }\end{array}$ & General & $\begin{array}{l}\text { Commonly consequent upon } \\
\text { eating poorly cooked pork. } \\
\text { A major outbreak occurred } \\
\text { during the first world war in } \\
\text { a army group of whom some } \\
1800 \text { were killed. } \\
\end{array}$ & \begin{tabular}{|l|} 
Partial immunity is \\
acquired (what does this \\
mean, I suppose that there \\
are no active worms but \\
the encysted organisms in \\
tissues remain intact) \\
\end{tabular} & $\begin{array}{l}\text { A wide variety of } \\
\text { domesticand wild animals, } \\
\text { often in arctic regions }\end{array}$ & $\begin{array}{l}\text { Effective treatment is available } \\
\text { for both the intestinal and muscle } \\
\text { stages In miceT-cell deprivation } \\
\text { leads to increase in worm burden } \\
\text { and reduction of thickness of cyst } \\
\text { walls. (10). }\end{array}$ \\
\hline
\end{tabular}


Table 7: Diseases That Do Not Readily Fall Into The Categories Already Considered.

\begin{tabular}{|c|c|c|c|c|c|c|c|c|}
\hline Disease & Infectious agent, target if any & y Location & \begin{tabular}{|l} 
ICD entry, \\
Impact
\end{tabular} & Susceptibility & Special risk factors & Immunity & \begin{tabular}{|l|}
$\begin{array}{l}\text { Primary reservoir } \\
\text { and vectors }\end{array}$ \\
\end{tabular} & \begin{tabular}{|l|} 
Comments and \\
Treatment?
\end{tabular} \\
\hline \begin{tabular}{|l|} 
transmissiblespongiform \\
Encephalopathies, \\
Four examples are given \\
in the $20^{\text {th }}$ edition of the \\
manualCreuzfeld-Jakob disease. \\
Variant CJD \\
Gerstmann-Straussler-Scheinker \\
syndrome Fatal Familial insomnia \\
\end{tabular} & \begin{tabular}{|l} 
Prions \\
Nervous system
\end{tabular} & Worldwide & $\begin{array}{l}\text { A81.0 } \\
\text { A81.01 } \\
\text { A81.09 } \\
\text { Potentially enormous }\end{array}$ & $\begin{array}{l}\text { Genetic differences in } \\
\text { susceptibility exist in } \\
\text { families that resemble } \\
\text { autosomal dominants }\end{array}$ & $\begin{array}{l}\text { NK except the genetic factors. } \\
\text { All the ones quoted here are } \\
\text { sporadic and not believed to be } \\
\text { exogenously acquired though } \\
\text { KURU and Iatrogenic CJD are } \\
\text { of exogenous origin.. Sometimes } \\
\text { long incubation times. }\end{array}$ & $\begin{array}{l}\text { None demonstrable either in } \\
\text { relation to adaptive or innate } \\
\text { immune processes. }\end{array}$ & & \begin{tabular}{|l} 
An extraordinary \\
collection of diseases \\
that has created great \\
controversy particularly \\
in relation to the human \\
consumption of prions \\
contained in bovine \\
products.
\end{tabular} \\
\hline Disease & Infectious agent, target if any & y Location & $\begin{array}{l}\text { ICD entry, } \\
\text { Impact }\end{array}$ & Susceptibility & Special risk factors & Immunity & $\begin{array}{l}\text { Primary reservoir } \\
\text { and vectors }\end{array}$ & $\begin{array}{l}\text { Comments } \\
\text { and Treatment? }\end{array}$ \\
\hline Pediculosis and phthiriasis & \begin{tabular}{|} 
Pediculus humanus \\
capitis(head louse)
\end{tabular} & Worldwide & $\begin{array}{l}\text { B85Common infestation } \\
\text { among schoolchildren } \\
\text { everywhere }\end{array}$ & Universal & None given & None given & Humans & $\begin{array}{l}\text { Tends to spread in } \\
\text { families all of whom } \\
\text { require CTX treatment. }\end{array}$ \\
\hline Scabies, sarcoptic itch. & Sarcoptesscabiei a mite & $\begin{array}{l}\text { Widespread, endemic } \\
\text { in many developing } \\
\text { countries but recent } \\
\text { epidemics in the } \\
\text { 'developed' world. }\end{array}$ & \begin{tabular}{|l} 
B86 \\
Irritant wih intense itching
\end{tabular} & Universal & $\begin{array}{l}\text { In immunodeficient andsenile } \\
\text { patients can present as a general } \\
\text { dermatitis }\end{array}$ & $\begin{array}{l}\text { Fewer mites succeed in establishing } \\
\text { themselves on previously infected } \\
\text { individuals. Hyperinfestation tends } \\
\text { to occur in immunosuppressed } \\
\text { individuals. }\end{array}$ & Humans & Usually treatable \\
\hline
\end{tabular}

Table 8: Approximate Percentage of Diseases in Various Categories.

\begin{tabular}{|c|c|c|c|c|c|c|c|c|}
\hline \multirow{2}{*}{\multicolumn{2}{|c|}{\begin{tabular}{|l}
$\begin{array}{l}\text { Approximate Number of diseases in the various categories } \\
\text { according to the taxonomic classification of the causal organisms }\end{array}$ \\
\end{tabular}}} & \multirow{3}{*}{$\begin{array}{c}\text { Miscellaneous } \\
4 \\
\text { Miscellaneous }\end{array}$} & \multirow{3}{*}{$\begin{array}{c}\text { Trematodes } \\
9 \\
\text { Trematodes } \\
\end{array}$} & \multirow{3}{*}{\begin{tabular}{|r|} 
Nematodes \\
14 \\
Nematodes
\end{tabular}} & \multirow{3}{*}{$\begin{array}{c}\text { Fungi } \\
15 \\
\text { Fungi }\end{array}$} & \multirow{3}{*}{$\begin{array}{c}\text { Protozoans } \\
14 \\
\text { Protozoans } \\
\end{array}$} & \multirow{3}{*}{$\begin{array}{c}\text { Viruses } \\
160 \\
\text { Viruses }\end{array}$} & \multirow{3}{*}{$\begin{array}{c}\text { Bacteria } \\
65 \\
\text { Bacteria }\end{array}$} \\
\hline & & & & & & & & \\
\hline & & & & & & & & \\
\hline \multirow{2}{*}{ Distribution } & Worldwide & 100 & 34 & 28 & 53 & 64 & 56 & 57 \\
\hline & Regional & & 66 & 72 & 47 & 36 & 44 & 43 \\
\hline \multicolumn{9}{|c|}{$\begin{array}{l}\text { The old classes given here relate to the issue of whether an outbreak of disease must be reported to WHO. The old classification is described in detail on pp XXJV-XXIX of the } 17^{\text {th }} \text { edition.The new insertion of ICD listi1 } \\
\text { severity of the diseases which to get some idea of what proportion are major threats is helpful. The severity classifications have in some instances changed over the years. }\end{array}$} \\
\hline \multirow{9}{*}{$\begin{array}{l}\text { Class.1 is most most } \\
\text { serious, } 5 \text { least harmful. The } \\
\text { classifications relate largely to } \\
\text { reporting requirements. }\end{array}$} & 1 & & & & & & 2 & 3 \\
\hline & $1 \mathrm{~A}$ & & & & & 7 & 4 & 3 \\
\hline & $2 \mathrm{~A}$ & & & 7 & & & 22 & 12 \\
\hline & $2 \mathrm{~B}$ & & & 7 & 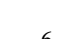 & & 2 & 31 \\
\hline & $3 \mathrm{~A}$ & & & & & & 6 & 2 \\
\hline & $3 \mathrm{~B}$ & & 11 & 7 & 6 & 7 & 26 & 12 \\
\hline & $3 \mathrm{C}$ & & 33 & 7 & 6 & 50 & 4 & \\
\hline & 4 & & & & 18 & 7 & 16 & 21 \\
\hline & 5 & 100 & 55 & 72 & 60 & 28 & 18 & 8 \\
\hline
\end{tabular}

Infect Dis Ther, Volume 1(2): 33-48, 2020 


\begin{tabular}{|c|c|c|c|c|c|c|c|c|}
\hline \multirow{4}{*}{ Impact } & Large & 25 & & & & 7 & 20 & 11 \\
\hline & & Miscellaneous & Trematodes & Nematodes & Fungi & Protozoans & Viruses & Bacteria \\
\hline & Medium & & 22 & 50 & 26 & 50 & 44 & 57 \\
\hline & Small & 75 & 77 & 50 & 74 & 43 & 36 & 32 \\
\hline \multirow{11}{*}{ Primary Target organ if any. } & Intestine & & 66 & 57 & & 36 & 8 & 20 \\
\hline & Lung & & & & 20 & 7 & 8 & 17 \\
\hline & Liver & & 22 & 7 & & 7 & 10 & 2 \\
\hline & Lymphatics and Lymph nodes & & & 7 & & & 2 & 6 \\
\hline & Lymphocytes & & & & & & 4 & \\
\hline & Nervous system & 25 & & & & 7 & 26 & 9 \\
\hline & Skin & 50 & & 7 & 66 & 7 & 8 & 31 \\
\hline & Eyes & & & 14 & & & 6 & 6 \\
\hline & Others including sex organs & & & & & & & 11 \\
\hline & Urinary tract & & & & & 7 & & \\
\hline & systemic & 25 & & 7 & 33 & 36 & 32 & 34 \\
\hline \multirow{2}{*}{ Susceptibility } & Universal & 75 & 100 & 100 & 60 & 64 & 100 & 95 \\
\hline & Resistance & 25 & & & 40 & 14 & & 5 \\
\hline \multirow[t]{2}{*}{ Special risk factors } & Malnutrition & & 11 & 7 & & 14 & 2 & 6 \\
\hline & & Miscellaneous & Trematodes & Nematodes & Fungi & Protozoans & Viruses & Bacteria \\
\hline \multirow{13}{*}{ Immunity } & Immuno-Suppression & 25 & 11 & 7 & 27 & 50 & 14 & 15 \\
\hline & Pregnancy & & & & & & 4 & \\
\hline & Gender & & & & & & & 8 \\
\hline & Embryos & & & & & & 4 & \\
\hline & Achlorhydria & & & & & & & 6 \\
\hline & neonates & & & & & & & 9 \\
\hline & young children & 25 & 11 & 14 & & 7 & 18 & 28 \\
\hline & Older children & & & & & & 4 & 9 \\
\hline & Adults & & & 7 & & & 8 & 14 \\
\hline & Old people & & & & & 7 & 4 & 12 \\
\hline & Occupational & & & & 13 & & 6 & 9 \\
\hline & $\begin{array}{l}\text { Other, such as diabetes general } \\
\text { illness }\end{array}$ & & & & 7 & 7 & 2 & 18 \\
\hline & Trauma & & & & & & 2 & 12 \\
\hline
\end{tabular}




\begin{tabular}{|c|c|c|c|c|c|c|c|c|}
\hline & Prior antibiotic treatment & & & & & & & 2 \\
\hline \multirow{6}{*}{ Immunity } & & Miscellaneous & Trematodes & Nematodes & Fungi & Protozoans & Viruses & Bacteria \\
\hline & $\mathrm{N} / \mathrm{k}$ & & & 64 & & 7 & 44 & 5 \\
\hline & $\mathrm{N} / \mathrm{k}$ & 25 & 22 & 57 & & 64 & 16 & 34 \\
\hline & Cell mediated & & & & & & 2 & 8 \\
\hline & General immunity & 25 & 11 & 14 & 20 & 36 & 80 & 38 \\
\hline & None or adverse effect & 50 & 66 & 28 & & & 2 & 18 \\
\hline \multirow{2}{*}{ Vaccines } & + & & & & & & 44 & 25 \\
\hline & -- & & 100 & 100 & 100 & 100 & 56 & 75 \\
\hline \multirow{4}{*}{ Point of access } & Skin & & 12 & 14 & 80 & 43 & 24 & 17 \\
\hline & Anus & & & 7 & & & & \\
\hline & Mouth & & 88 & 78 & 20 & 50 & 16 & 25 \\
\hline & STD & & & & 7 & 7 & 8 & 12 \\
\hline \multirow{12}{*}{ Transmission } & Vector to man & & & 21 & & 21 & 24 & 17 \\
\hline & Animal to man & & & & & 7 & 10 & 15 \\
\hline & Man to man & 75 & & & 33 & 36 & 6 & 20 \\
\hline & Autoinfection & & & 14 & & 7 & & 2 \\
\hline & Food & 25 & 88 & 78 & & 7 & 6 & 23 \\
\hline & & Miscellaneous & Trematodes & Nematodes & Fungi & Protozoans & Viruses & Bacteria \\
\hline & Air & & & & 20 & & 28 & 8 \\
\hline & Soil & & & & & & & 3 \\
\hline & $\begin{array}{l}\text { Secretions, mucosal contact except } \\
\text { sexual, but including respiratory } \\
\text { droplets }\end{array}$ & & & & & & 28 & 17 \\
\hline & Water & & & & 7 & 21 & & 11 \\
\hline & Inanimate penetration & & & & 7 & & & \\
\hline & Syringes & & & & & & 2 & \\
\hline \multirow{2}{*}{ Inapparent infection } & + & 25 & 100 & 50 & 20 & 86 & 34 & 14 \\
\hline & - & 75 & & 50 & & 14 & 66 & \\
\hline \multirow{2}{*}{$\begin{array}{l}\text { Recrudescence of latent } \\
\text { infection. }\end{array}$} & + & 25 & N/A & N/A & 7 & 57 & 6 & 2 \\
\hline & - & 75 & N/A & N/A & 93 & 43 & 94 & \\
\hline
\end{tabular}


In some instances, as with Meloidosis, there is no evidence of immune mechanisms, but it does seem that the infecting organism persists in patients infected years previously who, subsequently, have recrudescence of infection on becoming diabetic. The Streptococcal, Pneumococcal and Staphylococcal organisms are all common components of the normal flora associated with skin and upper respiratory tract. All are associated with a variety of unpleasant diseases, but we are not sure in mechanistic terms why what was ostensibly a balanced equilibrium (13) between host and parasite becomes unbalanced, in favour, as it were, of the parasite and active disease ensues. All the organisms concerned are numerous in relation to the varieties they display and for none of them is there a clear immunological controlling mechanism. If, for example, illness leads to alteration of the equilibrium between host and parasite what aspect of the various immune mechanisms is affected and is there any way we can identify this and perhaps intervene purposefully?

Direct zoonotic infections are found particularly among those who, as part of their occupation or as carers of companion animals, frequently encounter animals. In other instances, a non-human vertebrate or non-vertebrate reservoirs of infection can be the source of transfer to humans by vector organisms. The disease status or not of the vectors is of considerable interest but not often considered. Invertebrate vectors, for example, do not possess the adaptive immune mechanisms which the vertebrates do possess as a class. If the transferred organisms capable of causing disease, which is sometimes controlled by adaptive immune mechanisms, what if any is the control mechanism for the invertebrate vectors? Also, the immune status of non-human vertebrate organisms that serve as reservoirs of infection after transfer to humans is worth exploration. It does seem that many organisms which can potentially cause disease in man exist in an asymptomatic state in the reservoir host animals. Could it be that the symptoms of disease in the vertebrate organisms are attributable to some facet of the adaptive immune response rather than being necessarily prevented by it?

Clearly in relation to bacterial infection there are many strategies of interaction. Rather little has been done with vaccines with bacterial infections largely because the majority, though not all, of dangerous bacterial infections can readily be controlled by antibiotics. Where vaccination against a bacterial infection has been deployed it has sometimes been against a toxoid liberated by the infecting bacterium, cholera for example, or sometimes derived from phage in the bacterium rather than a product of the parasite genome, vide diphtheria. It looks as if each organism as an infection and as a cause of disease must be explored in detail if what is referred to as evidence-based medicine is properly to be practised.

\section{Viruses}

The absolute number of viral infections in man is of the order of two hundred the majority of which are arboviruses which reach human hosts via an arthropod vector. Taxonomically viruses are diverse, and it could be advantageous to group them according to the taxon they belong to. This has not been done consistently in the Table 2 which in the main lists them alphabetically by the name of the disease or group of diseases they are responsible for.
Of the viruses, of which account has been taken here roughly one third lead to chronic often asymptomatic infection. The remainder generate acute infections in many instances with life-long immunity to further infection by homologous organisms. As to whether this immunity is built upon a germ-free immunological memory is a matter for discussion. There are few treatments for viruses that are effective and those tend to have adverse side effects. On the other hand, some vaccines have been deployed successfully and, in some instances, attenuated live organisms have proved superior to dead vaccines. It is interesting to speculate how, where there is long term immunity but no evidence of persistence in intact form of the infective organism concerned, the immunity is maintained. The gut bacterial flora has something of the order of one hundred times more genes than are present in the human genome and there are in addition an unknown but probably large numbers of species of viruses. It could be that material detached from the organisms in the alimentary canal does gain access to the main body of the host and offers a massive library of cross-reacting antigens that can mimic antigens on the offending parasite. Such material could serve to maintain a low level of active immunity it is not certain whether food constituents stimulate immune responses in the gut but evidence will be presented later that this is likely. If it happens regularly this in another way, aside from persistence of a parasite, that a state low level active immunity could be maintained. Whether this speculation in time proves to have a factual basis it could be that the vaccinologists could tailor their efforts to include the maintenance of active immunity based on materials from introduced genetically manipulated micro-organisms rather than entirely on what could be a fiction that long lasting memory cells maintain long lasting adaptive immune response.

The arboviruses constitute the biggest single group of infective organisms and probably overall the least known scientifically. They are transmitted by vector through skin puncture and the great majority of them can engender disease free infections with lasting immunity against superinfection and the development of active disease. In evolutionary terms these organisms must surely collectively be the most important in influencing the human condition during the millions of years that our remote ancestors were hunter-gatherers with no urbanisation. At a guess it is from the ranks of the arboviruses that the $8 \%$ of the human genome that is thought to be of viral origin was recruited [2]. The significance of this is not immediately apparent except perhaps in relation to HIV that is possibly in the process in time of being established with less pathology than is now apparently the case in the human species [3].

AIDS is regarded at present as one of the most dangerous of pathogens though in fact presently it annually kills fewer individuals than does, for example, hepatitis B virus or Mycobacterium tuberculosis. The menace of HIV derives probably from its relative newness and initially its apparent inexorability. One facet of this virus which needs attention is its presently demonstrated capacity for mutability leading to switches of antigenicity that enrage those seeking appropriate vaccines. It is tempting to wonder whether, from the viral viewpoint, switching antigenicity is not an attempt to evade what seems to be an ineffective host immune response but part of a strategy to seek rapprochement with a host that has not, presently, got the capacity 
to make an accommodation response that would lead to a relatively peaceful co-existence. This is not particularly helpful to those presently infected with HIV who may die before the rapprochement formula is achieved but there is little in Nature to suggest that survival of all individuals by right, a view driven partly by the remarkable successes of our medical profession, is what happens in what could be termed the wild world.

When the myxomatosis virus was introduced into Australia in the 1950s, after a first failed trial, it began to kill the offending rabbits on such a massive scale that it would have been predictable that there would soon be no rabbits in Australia. In fact, this is not what emerged. Although it might seem likely that the surviving rabbits had been selected for resistance to the relevant virus, those who have investigated the phenomenon have shown that it is certain that the virus that changed. It is not as pathogenic as the form that was introduced into the continent [4]. Thus, in host/parasite interactions it has perhaps to be recognized that there are two life strategies involved of which mutability of the parasite is perhaps the more rapid in achieving co-existence. The immune response of the hosts in these circumstances could be orchestrated by the parasite as part of an overall accommodation system between host and potential parasite rather than the development, selectively, of genetically based resistance to the virus by the host.

CMV is a rather different example of viral infection from HIV or the arboviruses. In developing countries, it is usual for all the adult human population to be infected. It can cause problems in immunosuppressed individuals and one wonders why infants in utero who ostensibly, before the age of say twelve weeks of gestational age are immunologically incompetent, are not all killed by the viruses of their mothers. As it is a small proportion of infants are infected in utero and of them only a small proportion (10-15\%) develop disease caused by the virus. What are the factors that lead to the harm done to an exceedingly small proportion of perinatal infants? It is likely that the mother transmits anti CMV antibodies across the placenta and that these are passively effective in preventing infection of the developing foetus. Presumably, the protective effect of such antibodies in inhibiting the establishment of infection is lost as maternal antibody declines during the six months post-partum. Alternatively, the relationship with CMV may under normal circumstances in the mother be such that infectious viral particles are rare. In terms of the Topley and Wilson 'equation' (see the text below the reconciliation document) the dynamic equilibrium in this instance usually favours the host. Whatever the answer to these conundrums it is clear that there seems to be an immune response to CMV, but it is not associated with rejection of the parasite. It is intriguing to note that related CMV organisms found in animals simply are not found in man. Is it that human beings have learned how to reject these potential invaders or more simply those animal viruses simply do not have the capacity, perhaps lacking appropriate receptors to enable them to enter human cells? A comparable example would be the total incapacity of diphtheria toxin to kill mouse cells to which it cannot bind whereas human cells are acutely sensitive to the same material. It is important to consider these issues of host predilection in coming to an understanding of the interface between man and those organisms that can invade him with potentially detrimental effect. The immune response has been created by immunologists as an all-purpose reaction system capable of responding to any foreign intruders which it probably is not. But, more importantly, most 'foreigners' almost certainly simply do not have the capability of living in the human body. This is not an example of a host defence system but rather more a demonstration of what is self- evident that not all organisms are able to react with all other organisms.

Hepatitis $\mathrm{C}$ virus is an extraordinary example of menace to humans. Firstly, it is said by WHO to infect at least 60 millions or so of all living humans $c f$ HIV with 40 millions. Secondly, few (less than $10 \%$ ) of those infected realise they are infected. Thirdly, a high proportion of those infected ( $80 \%$ perhaps) become chronically infected essentially for the duration of their natural lives. Fourthly, a major problems is that a proportion (roughly 30\%) of those chronically infected takes between ten and forty years to become clinically apparent. Fifthly, we know virtually nothing about the immunological interface between man and HCV. Antiviral antibodies are produced but, in the present state of our knowledge they have no significance in relation to the staging of the disease. This raises an intriguing issue as far as intervention is concerned. Most vaccines are developed in order the better to prevent infection. Whether infection is in fact prevented or whether what happens is that disease, because of infection, is prevented is an issue that needs to be argued out in relation to each host/vaccine combination. We simply have little idea how to vary an ongoing immune response. In this age of molecular biology when almost any conceivable vaccine can be produced there are, nevertheless, presently few positive leads on so called therapeutic vaccination. In terms of the Topley and Wilson 'equation' (see the text below the reconciliation Table 8) we have a long way to go to balance the equilibrium in favour of the host as far as HCV infections are concerned. Prevention is a possibility as HCV infections is closely correlated with poor parenteral practices in hospitals and in the back streets, essentially reuse of poorly sterilised needles. It is thus a modern and preventable disease, recognized only twenty-five years ago (after a long period as non-A, non-B hepatitis virus). HCV is also, paradoxically, one of the few viral infections which is 'cleared' by the host for reasons that are far from apparent. Recently effective treatments for the condition using sofosbuvir or simeprevir have been applied and thus the issue of their immune status from a practical point of view is less pressing.

Before leaving the hepatitis viruses, that have no taxonomic affinities, it should be noted that before successful vaccination against HAV and HBV was started they infected roughly half the population of the world and the proportion even now will not be much less. Collectively the viral hepatitides constitute what is one of the biggest single health hazards to our global populations. A point that emerges from an overall look at viruses is that relatively few of them kill the majority of those infected. HIV presently is an example of a slow viral infection that is lethal in many instances though commonly many years after initial infection. Rabies virus is thought always to be lethal but, according to the ( $17^{\text {th }}$ edition of) the manual, only forty per cent of those bitten by rabid dogs in Iran died consequently. Was the majority immune? If they were immune was this an active process involving 
activation of the host immune response or was it failure of the virus to grow in an environment with which it has little experience. In many animals' rabies viruses exist in an asymptomatic state. Did this happen in the lucky Iranians?

Along the same lines Lassa fever viruses were likely to cause the most enormous havoc when the first American cases were taken to the States. There seemed no way of stopping the virus [5]. And yet it did stop and, when those parts of the world in which the virus is endemic were looked at more carefully, it was discovered that some ninety per cent of those infected remained asymptomatic. Again, the question arises as to whether the population of people concerned have been genetically selected for resistance to the virus. To my jaundiced eye this seems unlikely but, clearly, the resistance of the human populations to the viruses concerned in certain parts of Africa is greater than that of those few unfortunate Americans who initially met the virus in the USA. The mechanisms involved would merit investigation.

\section{Protozoa}

The protozoa offer a very mixed bag of chronic infections including malaria that is one of the major killers in those countries with infected mosquitoes. All the diseases seem to be treatable by chemotherapeutic attack upon the parasite though clearly those with a higher parasite burden and more complex invasion patterns are more difficult than the more superficial infections. (Leishmania, dermal and visceral indicates the contrast though there is also the issue of different species of infection being involved.). In a few instances immunity that is solid and long lasting seems to be acquired, i.e. the patients are disease free. As to whether they are chronically infected seems not actually to have been seriously addressed. In the instance of such a disease as malaria it seems likely that chronic persistent and asymptomatic infection is the usual condition among the indigenous population. Infection, it is assumed, from the prevalent sp. of malaria occurs in almost all infants soon after birth and in perhaps $15 \%$ of instances proves fatal without intervention. The great majority who survive these early infections probably remain chronically infected for the remainder of their lives or are perhaps continually re-infected without usually adverse effects. Is this state held at bay or maintained by the immunological apparatus? It depends how you think about it. Is anything known about the precipitating factors in an episode of malaria among the indigenous population most of whom will be demonstrably parasitaemic throughout their lives? This seems to be the kind of question like trying to find out why individuals in more temperate climates suffer quite often from the so-called common colds. It is not that there are no answers but there are many reputed risk factors often based on totally fallacious thinking (Table 3).

Trypanosomiasis attributable to the transfer of an infectious flagellate organism from another human or animal by means of various invertebrate vectors can be a most unpleasant disease but an interesting characteristic of the organisms concerned is that many of them can vary their antigenicity [6]. The usual interpretation of this fascinating property is that the invading organism is trying to avoid the immune responses of the host and of course this is a possibility. It can however be argued that the parasite if trying to persuade the host that it can produce an immune response capable of sustaining the relationship between the host and the parasite and incidentally providing edible and nutritious antibody for the parasite to take in. Such a notion does not fit with the standard paradigm of many immunologists and clinicians who commonly suppose that the parasite is trying to harm the host rather than to seek an accommodation slip. It is worthy of note that for example T. musculi which can ostensibly live in perfect harmony with its natural host mice [7] shows no capacity for antigenic variation but it might if transferred to a host where neither of the two components of the interaction had experience of each other.

Is disease potentially an immunopathological event and, if it is, should we better target the immunological apparatus rather than the parasite? It depends perhaps on a comparison with side effects and what if any are the collateral effects of interference with the immunological processes. In Ian Clark's experiments in mice [8] in which he successfully converted a potentially lethal plasmodial infection into an asymptomatic inapparent interaction by simple prior reduction in the capacity of the host to make TNF, there seemed, in the short term, to be no adverse effects. If immunopathology constitutes the major mechanism of the symptoms of diseases, as will be urged later, these tables contain interesting clues as to how inapparent infections are created and or maintained. For example, in relation to amoebiasis the very young seem only rarely to be affected by disease. Do they acquire the parasite without immunopathology or can the parasite for some reason not prosper in young organisms? Whatever the answer, there is, perhaps, a clue here to symptomless host/parasite interactions.

In eight of fourteen of the protozoan diseases immunosuppression is a major risk factor in rendering disease more severe. This suggests that immunity is a major defence mechanism but this conclusion, unalloyed, must be regarded carefully. In almost all circumstances that immunosuppression occurs there are many collateral effects any one of which can have major physiological consequences that could affect host/parasite interfaces. It is intriguing to note that so far there are no vaccines available for any human protozoan disease despite the strong evidence that immune mechanisms are important in relation to most protozoan parasite/host interfaces. Surely those indigenous human host populations in Africa who live with malaria all their lives are essentially 'vaccinated' and there only arise major problems (idiopathic tropical splenomegaly, for example) in relatively small numbers of those concerned. Of course the problem is made more complex in relation to malaria by the existence of at least three major pathogenic species but is it beyond our wit genetically to tailor a parasite having epitopes common to all three that could serve as components of a live 'attenuated' vaccine? The fancy methods that are being proposed to vaccinate against malaria (point of entry molecules and so on) perhaps will not succeed against such a complex organism as are protozoans with a very reactive plasma membrane capable of many changes when attacked or indeed ingestion and digestion of attached antibody molecules. Antibody can of course inactivate and kill parasites but it is not difficult to imagine scenarios where the rate of production of antibody and parasite is in balance or, as has been shown in mice infected with T. musculi, the parasite is restricted by antibody to a particular region of the body [7]. 


\section{Fungi}

There are some fifteen main fungal diseases, all chronic with often different presentations and pathogenicity according to the organism responsible. Three of the fungal diseases (candidiasis, aspergillosis and cryptococcosis) almost only occur as secondary to other debilitating conditions all of which could be said to involve immunosuppression. The clear inference is that the immune response normally keeps the relevant invaders out or prevents them creating disease. This needs looking at on a case-by-case basis. For example, contact with cryptococcal spores occurs almost daily in those crossing Time Square in New York but cryptococcosis, the disease, is only seen in few already sick individuals. The 'resistance' to infection is almost certainly primarily the physical barrier of the lung mucosa that is capable of capture and exclusion, perhaps by ciliary action, of considerable numbers of the spores. Is this equivalent to resistance based on a particular capacity of the adaptive immune system? In my view it is not largely because, in normal mice, if the physical barrier is circumvented by giving very few spores as an intravenous injection, death is likely. A similar argument could be applied to the entry of Aspergillus conidia though experimental evidence in support is not, as far as I know available. A rather similar argument could be used for apparent resistance (so-called) of humans to the infective agencies of Chromomycosis and Mycetoma, ie if the physical barrier to entry is disrupted or defective by for example cuts on the feet then the fungi concerned can occasionally get a toehold and cause harm (Table 4).

For the other disease that occurs as secondary to a pre-existing disease condition, Candidiasis, it is less easy to point to a particular portal of entry or specific weakness related to allowing fungal proliferation. The adaptive immune response may be the main defence against Candida but the argument for any significant adaptive immunological controlling mechanism is not strong. Candida infections for example are ubiquitous and, as is related in the manual, the organism is regarded as part of the normal skin and mucosal surfaces which any way are presumably the portal of entry of the organism. Is this normality imposed by the immune responses of the host or more simply due to failure of the infecting yeast particles to gain entry to the body except when it is in various ways debilitated? Whatever the answer there is a point of dispute on the present evidence as to whether the adaptive immune responses maintain the normal symptom free condition.

For only one of the fungal infections, Coccidioidomycosis, is it evident that there is a powerful and long lasting immune response capable of rejecting systemic infection. In Blastomycosis the case is not made, as the evidence is incomplete as presented in the manual. In Coccidioidomycosis, infections that have no clinical consequences are common but pathological disease is rare. Further some disease arises because of reactivation of latent infection consequent upon acquired immunosuppression. Here it can be argued that the adaptive immune response is an important regulatory mechanism at the interface between the fungus and its host. But it also must be considered that, under normal circumstances, the immune response comes to an accommodation with the invading fungus that can be stable and maintained over long periods of time. There is no evidence that the quoted long-lasting immunity is associated with the rejection of the parasite. It simply betokens resistance to the development of the disease. It would be intriguing to investigate this fungus/ host relationship to see exactly how the putative accommodation is achieved, what element of the fungus is recognized by the adaptive immune system of the host and what exactly goes wrong with it when overt disease erupts? It at least must be considered that the fault lies not with the parasite itself, as it is difficult to see why it should have changed, but with the development of immunopathological changes consequent upon alteration of the physiological controlling mechanisms of the immunological apparatus of the host. If this is the case attack upon the fungus may not necessarily be the only or even the most satisfactory way of reducing the disease condition.

Dermatophytoses seem to cause inconvenient conditions which are not life threatening. The implication is that the potential invaders are common and that repeated contact with them often in circumstances of slight abrasion can lead to the development of largely minor infections in which it may be that the adaptive immune response is in no way implicated. The barrier to entry to the skin is keratin and under most circumstances this is enough to prevent access to any deeper tissues. In such circumstances attack upon the fungus to reduce the irritation would seem to be the right strategy. Mucormycosis is perhaps a different case. There the attack upon underlying tissues almost seems to be directly due to erosion by the fungal hyphae rather than consequent upon any immunopathology. The details given in the manual of the lesions are insufficient to make any proper comment. The evidence for any immunological control of the fungal/host interface is, as presented, weak. Attack on the fungus would nevertheless seem a priori to be reasonable and probably the only way of control of the disease

Histoplasmosis is a relatively common condition with evidence that there is recognition by the adaptive immune response of the causal organism $(80 \%$ of some individuals in endemic areas can be histoplasmin positive on testing). In the manual the phrase inapparent infections are common and usually give increased resistance to infection' is somewhat ambiguous. It could mean that there arises a state of immunity from inapparent infections that involve the adaptive immune response, and this immunity inhibits the development of disease because of (further?) infection. It could perhaps mean that the mucosal surfaces are protected by, say, secreted IgA antibodies that reduce or inhibit entry to the various organs systems that can be harmfully affected by the fungus. If this is the case a specific mechanism can be postulated and searched for and, if found used to monitor susceptibility to disease or indeed used as a target for maintaining resistance, by for example transmucosal vaccination. Clearly here, as is true for paracoccidiomycosis, coccidiomycosis and sporotrichosis we are too short of information to make any satisfactory conclusions about mechanisms of resistance.

Reasonably effective fungicides exist for most but not all the infective fungi. What is however to be noted is that whereas with the fungal infections the word resistance is used in many instances in relation to the fungal/ host interface this is not so for most other host/parasite interfaces. It should be noted that the scientific 
literature presently contains many papers arguing that both innate and adaptive immune mechanism are active against fungal invaders and it may be that they contain significant truths nevertheless in experiments conducted by the present author and colleagues expert with the organisms in question, many years ago, it was possible to show that overall T-cell deficiency affected neither the speed nor final result of experimental infection of mice with either Candidaalbicans or Cryptococcus neoformans. Since those times (mid 1970s) the sophistication of immunological experiments has much improved and it may be that the more simple experimental models we adopted at the time are no longer useful. A recent review summarises what are regarded as presently tried methods of manipulating the immune response to offset the consequences of fungal invasion [9]. Having read the review, which is thorough, it gives many indications of improvement of immunological status in sick patients which in a variety of ways have been incapable of exercise of immune functions as found in normal individuals. It is not easy in the patients considered to define exactly how the complex immune functions are impaired and, perhaps for this reason, there areeven now no clear strategies put forward for the evidence-based amelioration of the immunodeficient immune states involved. It would nevertheless be useful for those who write the Manual to look carefully at the evidence presented by Loreto and his colleagues.

\section{Trematodes}

The trematodes induce a variety of chronic diseases one of which, schistosomiasis, figures on the 'wanted' list of WHO. No vaccines are quoted as available as is nearly true for all the eukaryotic (and fungal) parasites of man. Effective CTX exists in most circumstances. The transfer of infection often arises due to eating habits, usually either raw fish or improperly cooked meat. Immunity if any seems a variable feast. These organisms seem to exist in the host independent of immunity with the severity of infection determined simply by the number of infective organisms that have got in. Adverse consequences in some circumstances are due to redistribution of the parasite from an adult to larval forms that, in various encysted conditions, can be dangerous as space occupying lesions with the additional problems in some instances of eventual disruption with liberation of a variety of pharmacologically active substances (Table 5).

\section{Nematodes}

All the infections included are chronic a few of which are nasty. Most are to be found in tropical countries, a few worldwide. Universal susceptibility seems to be the rule. In no instance is immunity recognized and quantified. Our own work on Trichinella spiralis indicated clearly that in experimental mice a T-cell dependent immune response could regulate both the number of muscle encapsulated larvae and the thickness of the capsule wall - it was much thinner without T-cells [10]. My guess is that vaccination could influence some of those organisms that gain entry but that for others, such as pin worms that are relatively benign and remain outside the body, it would be of no significance. There are some five quite serious diseases among this collection on several of which the WHO has declared war. The Onchocerciasis efforts seem to have been reasonably successful.
In general, there exist successful chemotherapeutic strategies of elimination. Except of pin worms, no person to person transmission, pace strongyloidiasis in relation to which auto-infection is common. For all, except anisakiasis, reasonably effective anti-helminthic drugs are available. There seems not to exist any information on immunity or otherwise in treated patients (Table 6).

\section{Miscellaneous}

There is little to be said about this miscellaneous category except that it includes a disease that in cattle and in man has led in parts of the world, particularly in the UK to huge losses of money and some loss of life, largely in cattle. The disease concerned is one of four recognized prion diseases that are, ostensibly caused by accumulation of deformed protein molecules that in some way or for some reason have evaded or overwhelmed the standard mechanisms that exist for shaping proteins in a specific and appropriate way [11]. The reason for the infectiousness of the prions is not clear although a Nobel prize has been awarded for their discovery. Prions in the sense of deformed protein molecules are common occurrences. What is less clear is why under certain, ill-defined circumstances things 'go wrong. The issue of immunity in relation to prions seems on the face of it sensible as deformed proteins can elicit immune responses that relate to the deformity but, so far, immunity to BSE seems not to be on the cards (Table 7).

\section{Reconciliation}

As far as distribution is concerned about half of all recognized disease-causing organisms are worldwide in their distribution. In these days, when travelling between continents is common, this proportion may increase in time. The restrictions on distribution in part relate to differences in distribution of vectors such as mosquitoes, ticks and sand flies of particular kinds. It is also clear that many diseases are more common and rampant in tropical developing countries than in the temperate regions. The class of organism was put in for the sake of completeness and will not comment further on here except to point out the obvious fact that the more severe and dangerous diseases are largely caused by viruses or bacteria. If we were to look at domestic animals that in the tropics are ravaged by a wide variety of protozoan parasites a different story would emerge. Diseases in cattle in Africa include, on a potentially enormous scale, Trypanosome and Theilerial infections. For this table the old WHO classification which gave an indication of the reporting category to both local and global health authorities has been retained (Table 8).

The impact classification indicates roughly how important a disease was but the one plus, two plus, three plus categories adopted are too crude and of necessity applied arbitrarily. In some instances, the numbers of people dying annually are recorded but in some instances this is not stated in the Manual. The various diseases in addition to their lethality and morbidity, that impose strains on the health care services, have economic consequences on for example the labour force. There are other sources of information dealing with these issues, but overall figures of economic impact would perhaps be useful for PH officials to get some idea of the import of the diseases in question. These things are not written in criticism of the Manual, 
that clearly is written for American practitioners primarily but, faut de mieux, there seems little else enabling a global look at communicable diseases and the Manual does not confine its approach to diseases that are only significant in $\mathrm{N}$ America.

The target organ category looks at in broad terms what seem to be the primary disease sites. Clearly with many of the diseases in their worst and later manifestations major organ failure will be common often starting with the lung and heart. There are one or two things that stand out, ie the neurotropicity of some viruses emerges as does the predilection of bacteria to cause skin disease. Many of the diseases are recorded as systemic in relation to protozoa, bacteria and viruses. One of the most striking things that emerged is the high frequency with which it is recorded that susceptibility is universal or widespread. With the exception of the fungi and to some extent protozoan infections almost all human hosts, as far as we know, are susceptible to invasion by all the disease-causing organisms. There are very few exceptions. All the organisms to which attention is drawn cause disease in the broad sense the human species is, ipso facto, susceptible to the diseases in question. What the manual shows many times is that susceptibility to invasion is in many instances not a good indication of whether disease will develop. Nor, if disease does develop, what will be the outcome. Rabies virus, for example, in Iran it is written in the $17^{\text {th }}$ edition, only caused disease in $40 \%$ of those known to have been bitten by rabid dogs. On the other hand, the statement that when the disease caused by rabies virus develops it is always lethal indicates clearly the difference between being infected and developing disease. It should also be noted that a comparable statement does not exist in the $20^{\text {th }}$ edition. In foxes epidemiological studies [12] showed that disease was more rampant when the fox population density was highest. Is it ridiculous to see such organisms as rabies being part of the strategy for population density control at least in some wild animals!? There are many organisms with which we come in contact that live within us without causing disease or which do cause disease relatively rarely but not in a manner that leads suspicion to fall on a named organism. $\mathrm{CMV}$ is not far off such an organism nor, perhaps, is EBV. Both the organisms in question are essentially ubiquitous but only rarely cause disease.

There is a lovely statement in the 1964 Topley and Wilson, Vol 11 [13] as follows:

'The scientist shares with Humpty Dumpty the privilege of making words mean what he/(she) likes. But if we are to avoid confusion, we must at least give our words definite orders and see that they are obeyed. It happens that the state suggested by the word that we have chosen as a generic label for the phenomenon we wish to study is one about which we know extraordinarily little; because the study of true immunity, in the sense of complete natural insusceptibility to infection, does little to illuminate the relations of host and parasite that are our chief concern'.

It is a minor paradox that since 1964 our understanding of the genetic basis of susceptibility to infection on the one hand and development of disease once infection has occurred seems to have evolved relatively little. (pace the nice work that has been done largely in experimental systems on the genetic basis of the quantity of immune response to certain defined antigens. As far as I know this kind of work has not been extended to the more earthy fields of parasitic disease). Perhaps the genes we are looking for are for susceptibility to infection that really does seem ubiquitous. Perhaps we should be looking for other genes or other environmental factors that make this susceptibility to infection at least occasionally hazardous because of the development of disease. In standard thinking for susceptibility to infection to be a genetic characteristic it would seem sensible to suppose that there are advantages to the organisms that will become infected. Is this an outrageous suggestion? Man, for example, is a huge conglomerate of organisms with bacterial genes in all the mitochondria and $8 \%$ of the whole genome initially of extrinsic retro-viral origin. As Todaro [2] suggested many years ago the possession of viral genetic material may be highly advantageous particularly in enabling constant replacement of epithelia, even if it carries the occasional disadvantage of making development of cancer, usually in old age, more likely. Surely, we did not acquire all these other organisms that are an integral part of our make up without susceptibility to infection being genetically determined? Can it seriously be suggested that infectious disease does not have an evolutionary impact? The hackles of all the immunologists and parasitologists will rise with such an idea as the war game within which they plot their experiments and house their thinking is itself attacked as not necessarily the natural way of thinking about host/ parasite interactions.

Nevertheless, as Topley and Wilson in the same introductory context go on to write, 'Our main business is with those interactions between host and parasite that are characterised by a fluctuating equilibrium, and with the factors that shift this equilibrium, so that sometimes the parasite, sometimes the host, gains the upper hand'. Special risk factor analysysis, reveal some of the mechanisms that shift the Topley Wilson equilibrium referred to above.

As far as immunity is concerned in some instances there are no known immune mechanisms afoot. This corresponds to what I, to my surprise, found in the experimental systems which my colleagues and I developed in the '70s. I also note that most but not all viruses seem to elicit immune responses. The view among many immunologists is that the adaptive immune response is all purpose and designed to respond to any antigen, but this seems not to be entirely true. Not all infective organisms elicit immune responses. Perhaps the most evocative experience which justifies such an alarming statement derives from some studies fifty or so years ago which gave what we thought at the time was a totally negative result and would therefore be unlikely to be accepted for publication. In retrospect the study provides much information which is fascinating. My colleagues and I had conducted a reasonably systematic study of the histopathological consequences of stimulating, or not as the case turned out, the adaptive immune response. We used sheep red cells as tried and tested means of eliciting a response in mice and with a slightly different intent, oxazolone a powerful inducer of delayed type hypersensivity. We used pneumococcal polysaccharide as a third material as the response of T-cells to that was probably negligible. These T-cells, which we had played a large part in discovering, were, not surprisingly, a main interest for us. We discovered that there was a regular repeatable sequence of histopathologically perceptible stimulation of cells in responding lymphoid organs. Mitotic activity involving T-cells was 
followed by the development of germinal centres and the appearance of antibody forming cells (ref 23 leads to the published versions of this work). The picture was clear and being ambitious we elected to look at what happened when gnotobiotic mice were taken out of their bacteria proof containers and exposed to bacteria for the first time. It there was an adaptive immune response to such a huge influx of antigenic material we felt it would have spectacular consequences putting what we had found with sheep red blood cells and oxazolone to shame. We found that when put into clean boxes the retrieved gnotobiotic animals died overnight. Our microbiologist said it was due to opportunistic infection by Clostridium difficile or a similar organism. This finding offers another obvious lesson which will not be spelled out here. We then took out the gnotobiotic mice and put them into boxes that had been used by mice and which were festooned with mouse faeces. They all lived and seemed incredibly happy in their new environment. We culled five off these mice each day for ten days using gnotobiotic and normal mice as negative and positive controls. From each mouse we retrieved the Peyer's patches, the mesenteric lymph nodes, and the spleen all of which were prepared for histopathological examination. The 450 or so sets of slides were coded and read blind by an expert in the histopathological consequences of elicitation of an adaptive immune response. The result was to us, at the time, felt to have been a total waste of effort. Aside from a few metamyelocytes in the spleens of the 'contaminated' mice there was not the slightest sign of any immune activity. As a slight bonus, of which we thought nothing at the time, the germinal centres in the Peyer's patches of gnotobiotic mice were the same in number as those from normal (laboratory bred) mice, We seemed to have an answer to a conundrum which had puzzled us for some time - does a mouse, or a human being for that matter, make a vigorous adaptive immune response to and keep control by such means of its gut flora. As far as we could see from our massive, properly controlled and blindly read study the answer was no. The humble earth worm that, along with the other triploblastic invertebrates, does not have an adaptive immune response, must be grateful, nevertheless, for being able to ingest, every day, a diet largely consisting of microorganisms without adverse consequences. Huge contemporary interest in the microbiome is illuminated in part from the negative outcome of our study. The signs of adaptive immunity in the gut associated lymphoid aggregates of gnotobiotic mice suggests perhaps that standard feed components play a role in the lymphoid activity in the normal GALT (gut associated lymphoid tissue). There are other indications that the immune response to introduced biochemically complex living organisms is only a pale imitation of what might have happened if responses to all the potential epitopes capable of eliciting an adaptive response had been enabled but, sadly, this is not the place to pursue such a line of thought.

As far as vaccines are concerned the lack of some of these in relation to disease is related to the fact that it is has not been a commercial proposition to produce them. I have not seriously addressed the issue of whether live or dead vaccines are to be preferred. This is an argument that needs more space than is available here. There is however something that needs to be written. Some dead vaccines lead to lifelong immunity, for example diphtheria toxoid and to a great extent tetanus toxoid. The immunologists are in the main happy with this as they suppose perhaps rightly, that the immunological orchestra (Lancet leader 1967, 185-186) has a clear memory of the music it has played in the past. If that is true then, all the various categories of memory $\mathrm{T}$ and memory $\mathrm{B}$ cells with which the immunologists play games are secure and reasonably part of the mantras with which they punctuate their days. Also, it could seem quite ridiculous to suppose that there is an ongoing response to the injected toxoid when it was administered sixty years previously.

There are nevertheless various possibilities other than the immune response, like the nervous system, possessing a long memory. For example, after administration of the toxoid the immunised individual might have encountered the relevant bacterium (carrying the relevant phage that codes for the toxin) and taken it on board as a chronic asymptomatic infection in relation to which there is a continuous ongoing immune response that, under normal circumstances is stable; the fluctuating equilibrium that Topley and Wilson allude to but with no significant amplitude to the fluctuations. There is another explanation Corynebacteria are not uncommon neither are bacterial toxins. Also, the host organism has an enormous library of bacterial species with which it is in continuous intimate contact. Is it impossible that, given the initial priming injection with toxoid, the response is maintained as an ongoing affair by epitopes that are found in the host but which without the priming injection will not elicit sufficient immunity to negate any marauding toxins? If this is the case can vaccinologists, as suggested previously in this document, tailor the gut microbiota to deliver the required trickle of cross reacting antigenic material? In veterinary practice the concept of trickle infections, particularly in relation to multicellular parasites, is thought to play a role in maintaining resistance to further infection.

The design of vaccines could perhaps be influenced by such considerations as these. Now it seems largely to be determined by the classic view of the immunologists that sterile immunity is an achievable state. The evidence in the manual suggests that it is not common nor one to which is it necessarily reasonable to aspire. As far as the point of access category it is not particularly helpful. In many instances in a parasite gains access through the skin and that at the site of introduction there is an inflammatory lesion. If I were a parasite and I wanted to creep into the host in the dead of night and kill him or her stone dead and quickly I would not advertise my presence. I would not be antigenic. I would hide my light under a bushel (or whatever is handy). I would certainly not alert the host to my presence by bringing all his various inflammatory foot soldiers to the shore on which I had landed. Have we got it wrong? Is the parasite quite deliberately trying to persuade the host to produce a reaction that if it is successful will lead to a state, as Topley and Wilson put it, of (safe?) fluctuating equilibrium?

As an experimentalist I was much influenced by some experiments we undertook with mice some of which were variously immunologically impaired. Basically, the animals concerned were prepared to have either a normal or a deprived complement of T-cells with all the relevant controls that I will ignore as they did not detract from our conclusions. I want to draw particular attention to some work we [7] did with Trypanosoma musculi. This is a parasite that is 
found in various species of small rodent. As far as I know in the wild it does little harm. In the laboratory in normal mice injection of as few as one live tryps would give substantial otherwise asymptomatic parasitaemia evident from twelve days or so and declining quite quickly twelve days later. The infected animals gained weight at the normal rate and, as far as we could tell were hale and hearty. Their spleens, unusually for laboratory mice, were replete with very healthylooking germinal centres indicative of an ongoing systemic immune response. The infected animals were solidly resistant to further challenge. For the parasitologists, with whom I was working, this was an indication that the parasite had been exterminated and that the immune response was doing what it should do. In T-cell deprived mice a different story pertained. The parasitaemia developed at the same rate but continued to grow often over many months with eventually a fulminant condition arising and death following soon afterwards. This clearly shows that without T-cells control over the growth of the parasite cannot be achieved. 'Cell-mediated immunity in action' mutter the immunologists sagely. But was it?

I persuaded my parasitological colleagues to look at recovered normal mice for live parasites as we had a sensitive infectivity test. Eventually they found them in the kidney in an extremely healthy condition and ostensibly doing no damage. The tryps would be spending their days bathed in antibody (dare it be said that this was probably their main food?). Thus, in the absence of T-cells the infection eventually led to disease and death. In the presence of T-cells antibody was produced in buckets full and the parasite, albeit on a restricted scale, lived on. I found it difficult, with this example, not to suppose that the immune response functioning properly was responsible for safe retention not rejection of the parasite. It was in fact probably the most important factor in maintaining the equilibrium between host and parasite [13] without, in this instance, any obvious pathology. My hard-working parasitological colleagues, for whom I should say I had and still have the greatest respect, went on to try to persuade the parasite to 'come out' from the kidney otherwise there would not be, pace predation, any continuity of infection. In 'hyperimmune' mice with infected kidneys they tried steroids and, post-thymectomy, total body irradiation and restorative implantation of fresh syngeneic bone marrow to produce animals with few T-cells but nothing disturbed the equilibrium until, one day, in a burst of genius, they discovered that pregnancy in long term infected normal mice led to parasitaemia (personal communication). There were no adverse consequences noted of this disturbance of the equilibrium which could anyway be designed to pass the parasite to the foetuses. Sadly, we did not look for this. This small example coupled with much other evidence inadvertently provided by APHA began to push me to the view that the war paradigm of sterile immunity in relation to parasites was not totally satisfactory.

The last categories in the reconciliation table show that many infections can be asymptomatic and that some can recrudesce after long periods probably of equilibrium. The immune status of organisms with latent infections is not adequately researched but such research could be helpful in enabling us to decide which patients are likely to be stable with their latent infections. It is already known in AIDS patients in which latent infections, often of Pneumocystis carini or Mycobacterium tuberculosis, are thought to become active but the exact reasons why, except to show that in the broad sense the immune mechanisms probably regulate the equilibrium, is obscure. Also, as far as Mycobacteria are concerned, it may also be that a different sp. to that of the original infection causes the later problems. The main diseases that kill many humans globally of which, incidentally, there are very few, all show more infected individuals have few if any symptoms. Particularly for tuberculosis the statement that $90 \%$ of those in regions of the world where the disease is indigenous show no symptoms when first encountering the organism but are nevertheless probably carrying the Mycobacterium which causes the disease for life illustrates what seems to be counter intuitive.

\section{Overall Discussion}

\section{Biological Advantage}

The most usual method of teaching Biology without evocation of Special Creation, which will not be done here, is to suppose that a process of evolution of living organisms has occurred. The fossil record supports such a way of proceeding and the monumental work of Darwin, on the selection of advantageous forms of life capable of better succeeding in our diverse global climate, provides a framework for the process to occur. The relatively recent discovery of the genetic apparatus in the early days of the last century [14] offered a mechanistic basis for evolution to occur by selection of genetic constructs, point mutations as they are often called, offering survival advantage to their possessors. The role of point mutations in the process of natural selection will not be queried but it will be suggested, based on the survey of the APHA handbook, that it is far from the only method of genetic selection that exists. Most recent biological teaching, to make sense of the tremendous morphological diversity of living organisms particularly the multicellular eukaryotes of which the human species is an example, has continually posed the questions involved in deciding on the possession of properties of biological advantage. For example, the fins of fish facilitate their movement in a liquid environment, the wings of birds enable them to move in air, the possession of chlorophyll by many plants enables them to fix solar energy, a process on which humans are presently totally reliant, and the hair of mammals helps to keep an homoiothermic organism such as Homo sapiens warm in cold climates. Students of biology have laboured over such issues ever since Darwin published his groundbreaking study on diversity as the basis of biological evolution but it will be suggested that the concept of monophyletic evolution of single species should be queried and replaced by an alternative with many species of organisms working together to constitute the units for evolutionary advancement.

\section{Communicable Diseases and Vaccination}

It is about such studies, exploring the biological advantage of possession of an immune response, that the present review of communicable diseases in man has been conducted. On the face of it, organisms that can invade and clearly in some instances harm humans seem to constitute a selective disadvantage and the immune response seems tailored to overcome this disadvantage. The contemporary social, disruption following the emergence and depredations made on the human species of the SARS-CoV-2 virus which can give rise 
to the Covid-19 severe respiratory disease, and the apparent failure of the immune mechanisms always to act protectively, underlines the importance of this manner of thinking. The standard way of getting round the problem is to evoke prophylactic vaccination, a process known in outline for centuries. Edward Jenner is often given great credit for showing, in 1798, that vaccination, in humans, using a form of smallpox 'vaccinia' virus derived from cattle, could offer protection from the great harm that the wild type human pox virus could wreak [15]. That it took till October 1977 to extirpate the disease from human populations [16], by a combination of vaccination and contact identification using the immunisation technology invented by Jenner, inter alia, shows that highly beneficial changes in medical practice can take considerable time to become established but, nevertheless, vaccination worked. The immune response is certainly in part protective, but it will be proposed that there are other aspects of its functioning. It is useful to amplify such a statement by reference to the information given in the American Public Health Association Manual of Control of Communicable Diseases which aims to review nearly all the presently known such diseases with attention to the kind of information needed by Public Health practitioners to reduce their effects when they harm humans.

\section{The Evolutionary Perspective of the Immune Apparatus}

Humans live in an increasingly sanitised world in which as far as possible micro-organisms are given short shrift as they are believed to be potentially dangerous and to be capable of causing disease. There is no doubt that there is a sound basis for such a belief in that there are some such organisms that can be pathogenic i.e., capable of causing harm in human populations. It is, nevertheless, worthwhile noting, against an evolutionary perspective, that the selective mechanisms by which the human body effects an immune response were probably put in place more than five hundred million years ago when vertebrates were first found in the fossil record. This is well before the advent of what we now know as the medical profession. The point about the medical profession is that the mores of the present age regard all human life to be valuable and that in those circumstances, where for medical reasons it seems to be threatened, it is the duty of the profession to do their best to reduce harm due to infection and where possible save lives. No such remediable measures were available at the time that Homo sapiens or his earlier progenitors first roamed the earth. Life then, for the extant humans, was much as it is now for wild animals and plants. It can reasonably be argued that if we wish to estimate the biological significance of immune mechanisms in an evolutionary perspective it is to the 'wild' situation that we should look. This in no sense to argue that the medical profession are not doing a good job or that their mores are to be changed but simply to assert that the medical profession and the public health experts have moved the demographic structure of human populations massively in the last hundred or so years and that this demographic change can distort the way we think about an ancient interface system, between man and his complex environment, such as that constituted by the various facets of the immune response.

\section{The Adaptive and the Innate Immune Responses}

For historical reasons, our thinking about immunity in recent years has been almost totally dominated by our pre-occupation with what immunologists call adaptive immunity. This property is possessed only by vertebrates [17] and its pursuit has largely led us to ignore the fact that the innate immune response is also an integral part of the total mechanisms of immunity. Innate immunity is not only a property of vertebrates but also functions in multicellular invertebrates [18] many of which have, in their adult forms, an exoskeleton, an alimentary canal and three basic blast layers in the early stages of their ontogenesis - so called triploblasts. The innate immune response in all such organisms has a system of cells that can become phagocytic and which, operating inside the body which contains them, in part if not exclusively, using a system of toll receptors [19], can find, ingest, and destroy living invaders and act, in circumstances in which cells have been damaged or killed in the body, not necessarily as consequence of infection, to perform a clean- up operation.

The differences between adaptive and innate immunity in terms of their mechanisms and overall purpose have been dealt with extensively elsewhere [20]. Here it only needs to be said that the adaptive immune response is specific and capable of tailoring an immune response to relate to the inducing antigenic stimulus by the production of antibodies which have specific binding sites for the inducing antigen. In addition, it is widely argued that specifically cytotoxic cells are produced. It must also be noted that adaptive immunity depends to a great extent on the existence and activities of two populations of lymphocytes terms $\mathrm{T}$ and $\mathrm{B}$ cells, the former of Thymic origin [21] the latter from Bone marrow. In vertebrates $\mathrm{T}$-cells have a variety of ascribed functions of which one of the first to be discovered was to work synergistically to facilitate the production of antibodies by $B$ cells [22]. These two populations of lymphocytes are often credited with a potentially long-term memory of past activities perhaps comparable to memory possessed by organisms with a brain. This notion of immunological memory will be queried not as necessarily wrong but one which should be argued about.

\section{The Adaptive Immune Response, Reject or Acceptor of Invaders}

The adaptive immune response is seen by most medical practitioners, by many contemporary immunologists and often by parasitologists as primarily a defensive mechanism ideally capable of rejecting living invaders and dealing with foreign bodies of any kind. This view has been criticised [23-25] and the counter suggestion made that the adaptive immune response in evolutionary terms exists to assist accommodation of invaders. The name adaptive against this background can suggest either rejection or accommodation with, in the views of its protagonists, the latter being commonly possible and the former less often observed. These notions are not in general popular either with immunologists or parasitologists but nevertheless deserve consideration here. Probably the vertebrates appeared later in evolutionary time than the invertebrate organisms which are generally supposed to be their precursors. Accepting this view, it is worth considering briefly why the adaptive immune response, 
characteristic of the vertebrates, was added, in response to a selective advantage, to the innate immune response of their precursors. The innate immune response has no specific memory such as is seen as a property of the adaptive response. It could be that the acquisition of a specific memory is a selective advantage. Equally because of the existence of the substantial array of isotypes of immunoglobulin antibody and their even greater array of idiotypic diversity associated with the adaptive immune response it could be seen as providing an all- purpose far more extensive protective reaction to invasion than the innate immune response alone. It seems to make good sense, but it can be argued that if that were the case vertebrates would have been selected for their capacity to reject pathogenic organisms capable of reducing their viability. In fact, a significant finding from the APHA manual is that humans and incidentally their domestic animals very often live for long periods of time asymptomatically with latent disease forming organisms. Also most disease causing organisms are found to be symptom free in species other than the target of interest. For example Theileria parva which can cause a disastrous and almost always lethal disease in non-indigenous Zebu cattle in East Africa is to be found asymptomatically in native species of [26] bovids (buffalo). That the great majority of viruses and bacteria do not cause disease in man could be attributed more to the organisms concerned not having a necessary biochemical affinity with hosts that they do not invade. The APHA manual makes it clear that susceptibility to the infections known to be capable of causing disease is almost universal. If such susceptibility were dangerous perhaps the all-purpose apparatus of the adaptive immune response will deal with the consequences of the 'free' entry of invaders. Of course there are many non-immunological barriers to entry such as mucosal membrane secretions with antimicrobial properties and physical barriers such as provided by sturdy keratinised skin but when these barriers, for whatever reason, have been by-passed successfully invasive organisms often do not cause disease symptoms or only those that can readily be dealt with by the various responsive systems possessed by the vertebrates, particularly the elements of the innate immune response which act as very effective sentries in locating and exterminating foreign organisms intent on immigration. Without doubt the adaptive immune response can control the scale of invasion which for various reasons has not been dealt with by the innate system [7] but it is not too difficult to show experimentally that long term persistence can be associated with the presence of circulating antibody specifically capable of binding to and inactivating, though not exterminating invaders [7]. It has even been argued in relation to eukaryotic single celled organisms that antibody bound by specific idiotypic ligands to their target cells could offer a high level nutritious proteinaceous diet [7]. Fie!

Recent studies on Covid-19 patients claimed that high antibody levels were present in seriously ill patients but far less frequently in most infected individuals who were asymptomatic [27]. Is it totally ridiculous to argue that elements of the adaptive immune response contributed in some way to the sickness of the patients with severe disease but, in those who were asymptomatic, no such harmful effects were seen for the simple reason that the adaptive immune response was not so active? Alternatively, the asymptomatic patients, using their adaptive system or their innate immune response, had restricted the prevalence of the invading virus and thus only a minor response in terms of inactivating circulating antibody was observed.

Invertebrate vectors which facilitate the introduction of potentially pathogenic invaders of vertebrates do not themselves seem to suffer disease symptoms or at least do not have sufficient restriction of their movements to prevent them being capable of gaining entry to the vertebrate host usually with the aim of getting a blood meal. Is the apparent general lack of suffering from disease in infected invertebrates because they do not have adaptive immune mechanisms? There are no easy ways of resolving these apparently conflicting interpretations of observations. Theprevailing view is that pathogenic microbes exist to harm their hosts and must be avoided or killed. The terminology adopted by the human protagonists of this kind of approach is that used in waging wars and it is difficult not to be sympathetic but it must be pointed out that the possibility of mutual benefit as a consequence of infection should be considered. The benefit to the potential parasite is that it gets somewhere safe to live. The long-term advantage to the host could be that it gains an indwelling source of genetic material. If this seems bizarre it should be remembered that two major steps in evolution, firstly the formation of eukaryotic organisms from fusion of several species of archaea and bacteria with subsequent simplification of the genomes involved as Lynn Margulis [28] has so elegantly pointed out, led to the emergence of the nucleated cells of which all the living organisms that not microbial are now composed. The mitochondria which are the relics of these long-ago events still retain a small fraction of genetic material known to be of microbial origin. The mitochondria are essential vital energy managing organelles of which the much-simplified genetic material, derived from what were initially free living organisms, enacts the required energy managing function.

Is it too difficult to imagine a protracted evolutionary sequence involving contact between living organisms leading sometimes to invasion, the initial stages of which in evolutionary time could be tempestuous and dangerous, facultative parasitism it could be thought of, followed by period of accommodation, obligate parasitism, and perhaps in time genetic simplification of the invaders and total loss of their independence? The microbial flora which all triploblastic organisms possess, the acquisition of which was a major step in evolution, shows convincingly that organismal relationships can be mutually beneficial despite the massive differences in the life-styles and genetic constitutions of the organisms concerned. Several billion years ago almost the first fossil organisms to be discovered, stromatolites, were complex symbiotic associations. Symbiosis is essentially a universal phenomenon and not one easily predicted by a theory of evolution only advancing by selection of advantageous point mutations. The disadvantage to host of harm or death as consequence of invasion of course exists but it can be argued that this is irrelevant in evolutionary terms however abhorrent it is to a species such as Homo sapiens which prides itself on being able to keep all the individuals of its species in good health. The innate immune response is swift and lethal. Impose on this assassin the mechanism for adoption and rehabilitation of immigrants and it can be argued that this potentially accelerates evolution by creating greater gene pools that have the capacity over time for responding to a greater degree of environmental vicissitudes than can be arrived at by monophyletic notions of evolution. 


\section{Non-Immunological Consequences of Activation of the Immune Apparatus - Inflammation}

Over the years it has become apparent that immune cells of all kinds activated in vitro or in vivo produce a wide variety of proteins other than the specific antibodies, which are derived from B-cells transformed into plasma cells. The various cytokine products, in addition to antibodies, are exported into the surrounding medium whether this is a tissue culture dish or extracellular spaces. In this way activation can be, in addition to be concerned with the response to an antigenic stimulus, part of a signalling process having consequences on surrounding cells often in vivo on adjacent tissues and systemically. The secretions include what are called paracrine and autocrine hormones which act locally. Wikipedia has this to say:

"When macrophages are exposed to inflammatory stimuli, they secrete cytokines such as tumour necrosis factor (TNF), IL-1, IL-6, IL-8, and IL-12. Although monocytes and macrophages are the main sources of these cytokines, they are also produced by activated lymphocytes, endothelial cells, and fibroblasts."

The cytokine secretions from activated cells of the immunological apparatus, whilst they can also act locally in the paracrine sense, can also have systemic endocrine effects. The relationship between these cell products and the rather better-known products of the endocrine organs, the thyroid, the adrenals, the pituitary, and the sex organs, for example, is less well understood. There are other organs which secrete hormones such as the alimentary canal and again the relationship between these and the other secretions which can act hormonally in the sense that they have effects remote from their sites of production is far from clear though in the years to come research will sharpen up our knowledge. The cleaning operation after damage to cells in the previously whole body, referred to above, is an aspect of inflammation executed by elements of the innate immune response operating internally. This mopping up is comparable in some ways with the external debridement of wounds surfaces by the medical profession to expedite the commencement of the healing process. The clean- up operation can involve what are called pro-inflammatory constituents of the innate immune system. All being well they give way in time to anti-inflammatory components associated with the healing process. This transition often goes smoothly but if the pro-inflammatory influences do not give way in time to the next phase symptomatic problems can arise which, to those suffering from them, can be unpleasant, dangerous, and potentially lethal. Presently we are not fully capable of easing the transition process, but it seems likely that we can begin to identify the internal mechanisms involved. It must be made clear that the account given here is an oversimplification in that some of the cytokines identified as pro-inflammatory can be anti-inflammatory and vice versa. The whole array of inflammatory molecules is highly complex and perhaps for this reason the general analytic methods which will need to be applied to further its control have not yet been fully discovered but a start has been made.

The Wikipedia entry summarises these issues and points particularly to a phenomenon, the secretion of TNF, tumour necrosis factor, which, as Ian Clark has pointed out for over forty years, [29] is vastly important in relation to disease symptoms including lethality. His argument based on an elegant series of experiments showed initially that the lethality of an infection of a species of Plasmodium in mice could be abolished prophylactically by reduction of the capacity of the recipient animals to produce TNF. Clark went on to show that TNF minus mice did not get sick and die, and if he injected normal animals with TNF, he could elicit disease symptoms. The issue is whether such a mechanism relates to the symptoms of some or all infectious diseases and whether it can be predicted which organisms will be most affected by the pathological effects which can derive from immune activation. Clark's work with infection of various strains of mice with Babesia points a way forward in this respect. He found that the pathogenesis of Babesia could be predicted from a knowledge of the sensitivity of the species or subspecies strain of host animals to LPS, a bacterial product which has powerful physiological consequences due to its capacity to induce massive and dangerous inflammation [30]. Beyond such a finding if we could identify by some clinical biochemical markers those individuals most at risk from what is in fact immunopathology, lies the issue of how we can intervene to reduce such processes which, ex hypothesi, can be very harmful and should if possible be controlled.

Some of these issues are considered in a recent paper [31] summarising what I, an immunobiologist, believe is how we should think of infectious disease as a step in the evolution of a greater degree of genetic complexity. Such a message to those who die as a consequence of infection is not helpful and of course the medical profession should continue to strain to keep sick people alive, but it is likely that some of their efforts are not mimicking the ways that over the ages man has emerged from the evolutionary swamp.

In summary:

1. Genetically based resistance to disease is uncommon compared with susceptibility to invasion by potential pathogens.

2. Immune activities are both helpful and potentially harmful to humans we should seek better to understand the mechanisms by which the harm element is brought about in addition to learning more about the general physiological benefits of immune processes.

3. Only to think of attacking and killing invaders is to disregard the immunopathological processes that often and probably always are involved in creating the symptoms of disease.

4. Inflammation arising from activation of immune cells occurs and it could often be better to attempt control of the host response than necessarily waging war on the invading organism. Most interaction between living systems are complex and involve activities which could be thought akin to playing table tennis i.e., the players change their activities according to the way that their partner in the game has played. An organism that can replicate in minutes rather than years and where the process of replication is prone to mutational error has a much better chance of creating advantageous genetic diversity.

5. It should be better recognised that both adaptive and innate immunity exist in humans and the roles that each of these mechanisms both in relation in the broad sense to infection and the maintenance of good health should be considered. 
6. There are many problems susceptible to solution by active research by immunologists that arise from perusal of the APHA manual on Control of Communicable diseases in man.

7. The reasons why so many diseases are more severe in those who are said to immunosuppressed or physiologically at a disadvantage, diabetic say, should be better investigated than is presently the case. In balanced ecosystems predation occurs but the loss of life due to it is easily balanced in several ways. Man, is a complex example of a whole series of ecosystems and their structure and maintenance might be facilitated by better recognition of this fact.

8. Particular attention should be given to the role that our microbiome friends play in the maintenance of health and how this property can be augmented and maintained perhaps by pro- and pre-biotics which have defined effects on the gut flora [32-34].

\section{Acknowledgements}

I wish first and foremost to thank my friend and erstwhile colleague Professor Page Faulk for bringing the APHA Manual to my attention. Over the years I was involved in active experimentation my colleagues and I published many papers, and their contributions were recognized by joint authorship. I thank them here for their skill, support, and enjoyment of the work we did together. As far as parasitic disease is concerned Professor Ian Clark offered an insight into the significance of Innate Immune mechanisms with his powerful studies of TNF and I thank him for his work and continued support. Prof Michael Doenhoff initiated me into the arcane world of Schistosome infections. I thank him for scientific discussions and the great fun we had together. I am grateful to Prof Lee Nelson who told me of the phenomenon of Microchimaerism which offers the possibility for all humans to have beneficial activity of immunological mechanisms they contain which they acquired following movement of cells from their mother during pregnancy. Cells acquired in this way offer generational continuity over and above the standard Weissman model of inheritance entirely through the genetic apparatus of the zygote. The importance of microchimaerism is probably presently understated. Professors Pierre Viens and Geoff Target produced results of experiments which revolutionised my understanding of adaptive immune responses and I thank them for their patience, friendship, and collaboration. Professor Max Murray and his colleagues in the Veterinary College of Glasgow University led me gently into the world of parasite disease in cattle and from them I learned and continue to learn a great deal. More recently Dr Chris Owens and Professor Bruce Reid have had considerable influence on my way of thinking, and I thank them for that. Dr Aamir Ahmed is a top rate physiologist with expertise in the electrophysiology of cell membranes, His regular discussions with me have both encouraged me to think and offered methodological insight which has been most valuable. My friend and wife, Agneta Lando has been unstinting in her support, checking manuscripts and offering encouragement to continue. She has been throughout invaluable.

\section{References}

1. APHA handbook $20^{\text {th }}$ Edition (2015) Editor Daniel L Heymann, APHA Press.

2. Todaro GJ, Huebner RJ (1972) The viral oncogene hypothesis: newevidence. PNAS 69: 1009-1015.

3. Kevin K Ariën, Guido Vanham, Eric J Arts (2007) Is HIV-1 evolving to a less virulent form in humans? doi: 10.1038/nrmicro1594PMCID: PMC7097722.

4. Ricklefs, Robert E (1979) Ecology, Chiron Press, NY, 2nd Edition, 632-633.

5. “Fever: Hunt for a New Killer Virus" (1975) John G. Fuller (eds.). Ballantine Books.

6. Vickerman K (1978) Antigenic variation in trypanosomes. Nature 273: 613-617.

7. Viens P, Targett GAT, Leuchars E, Davies AJS (1974) The immunological response of CBA mice to Trypanosome musculi.1. Initial control of the infection and the effect of T-cell deprivation. ClinexpImmunol 16: 279-294.

8. Clark I (2009) Parasitology 136: 1457-1468.

9. Érico S Loreto, Juliana SM Tondolo, Sydney H Alves, Janio M (2017) Santurio Immunotherapy for Fungal Infections DOI: 10.5772/66164.

10. Walls RS, Carter RL, Leuchars E, Davies AJS (1973) The immunopathology of trichiniasis in T-cell deficient mice. Clinexpimmunol 13: 231-242.

11. Prion disease Wikipedia, 2020.

12. Michelle K Morters, Olivier Restif, Katie Hampson, Sarah Cleaveland, James L N Wood, et al. (2013) Evidence-based control of canine rabies: a critical review of population density reduction. J AnimEcol 6-14.

13. Principles of Bacteriology and Immunity (1964) Topley and Wilson, Fifth Ed, Edward Arnold.

14. The Nobel Prize in Physiology or Medicine 1933 was awarded to Thomas Hunt Morgan "for his discoveries concerning the role played by the chromosome in heredity."

15. Riedel, Stefan (2015) "Edward Jenner and the history of smallpox and vaccination". Proceedings (Baylor University. Medical Center). Baylor University Medical Center. 18: 21-25. doi:10.1080/08998280.2005.11928028.

16. Smallpox WHO Factsheet. Archived fromthe originalon 21 September 2007.

17. Gary W Litman, Jonathan P Rast, Sebastian D Fugmann (2010) The origins of vertebrate adaptive immunity. Nat Rev Immunol 10: 543-553.

18. Janeway C, Travers P, Walport M, Shlomchik M (2001) Immunobiology (Fifth ed.). New York and London: Garland Science. ISBN 0-8153-4101-6.

19. Thierry Vasselon, Patricia A (2002) Detmers, Toll Receptors: a Central Element in Innate Immune Responses. Infection and Immunity 1033-1041.

20. Sagar Aryal (2018) Difference between Innate and Adaptive ImmunityMicrobiology Info.com.

21. Leuchars E, Cross AM, Davies AJS, Wallis VJ (1964) A cellular component of thymic function. Nature 203: 1189.

22. Davies AJS, Leuchars E, Wallis V, Marchant R, Elliot EV (1967) The failure of thymusderived cells to produce antibody Transplantation 5: 222-231.

23. Davies AJS, Hall JG, Targett GA, Murray M (1980) The Biological Significance of the Immune Response with special reference to Parasites and Cancer. J Parasitol 66: 705-721.

24. Davies AJS (2012) Immigration control in the Vertebrate Body with special reference to Chimerism. Chimerism 3: 1-8.

25. Davies AJS (2008) Immunological Tolerance and the Autoimmune Response. Autoimmunity Reviews7: 538-544.

26. W Ivan Morrison, Johanneke D. Hemmink, Philip G. Toye Theileriaparva: a parasite of African buffalo, which has adapted to infection and undergo transmission in cattle. International Journal for Parasitology 50:403-412.

27. Orlowski EJW, Goldsmith JA (2020) Four months into the COVID-19 epidemicSweden's prized herd immunity is nowhere in sight. JRSM 113: 292-297.

28. Sagan D, Margulis L (1986) Origins of sex: three billion years of genetic recombination. New Haven, Conn: Yale University Press. 
29. Ian A Clark (2007) How TNF was recognized as a key mechanism of disease. Cytokine Growth Factor Rev 18: 335-343.

30. Clark I (1982) Correlation between susceptibility to malaria and babesia parasites and to endotoxicity. Trans RS Trop med 76.

31. Davies AJS (2020) Thoughts of an Immunobiologist about Covid-19. Infect Dis Ther 1: 1-6.
32. The Diet Myth, The Real Science behind what we Eat. Tim Spector (2016) Wiedenfeld and Nicholson.

33. I contain Multitudes (2016) The microbes within us and a grander viewof life. Ed Yong, Vintage.

34. International Scientific Association for Pro and Pre biotics, web site where, in 2017, the meaning and significance of these entities was defined. Nature Reviews Gastroenterology \& Hepatology 14: 491-502.

\section{Citation:}

Davies AJS (2020) Communicable Diseases in Homo sapiens for Immunologists. Infect Dis Ther Volume 1(2): 1-48. 